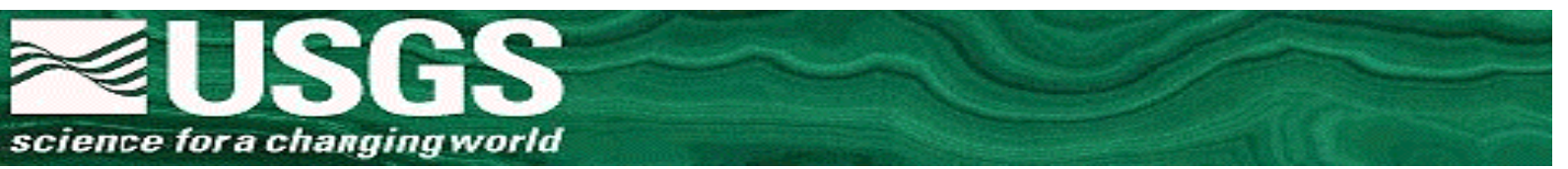

\title{
Chemical Composition of Samples Collected from Waste Rock Dumps and Other Mining-Related Features at Selected Phosphate Mines in Southeastern Idaho, Western Wyoming, and Northern Utah
}

By

Phillip R. Moyle and J. Douglas Causey ${ }^{1}$

Western U.S. Phosphate Project ${ }^{2}$

Open-File Report 01-411

2001

This report is preliminary and has not been reviewed for conformity with U.S. Geological Survey editorial standards or with the North American Stratigraphic Code. Any use of trade, product, or firm names is for descriptive purposes only and does not imply endorsement by the U.S.

Government.

\section{U.S. DEPARTMENT OF THE INTERIOR U.S. GEOLOGICAL SURVEY}

\footnotetext{
${ }^{1}$ U.S. Geological Survey, Spokane, WA 99201

${ }^{2}$ Prepared in collaboration with Bureau of Land Management, Forest Service, Agrium U.S. Inc., Astaris LLC, J.R.

Simplot Company, Rhodia Inc., and Monsanto
} 


\section{CONTENTS}

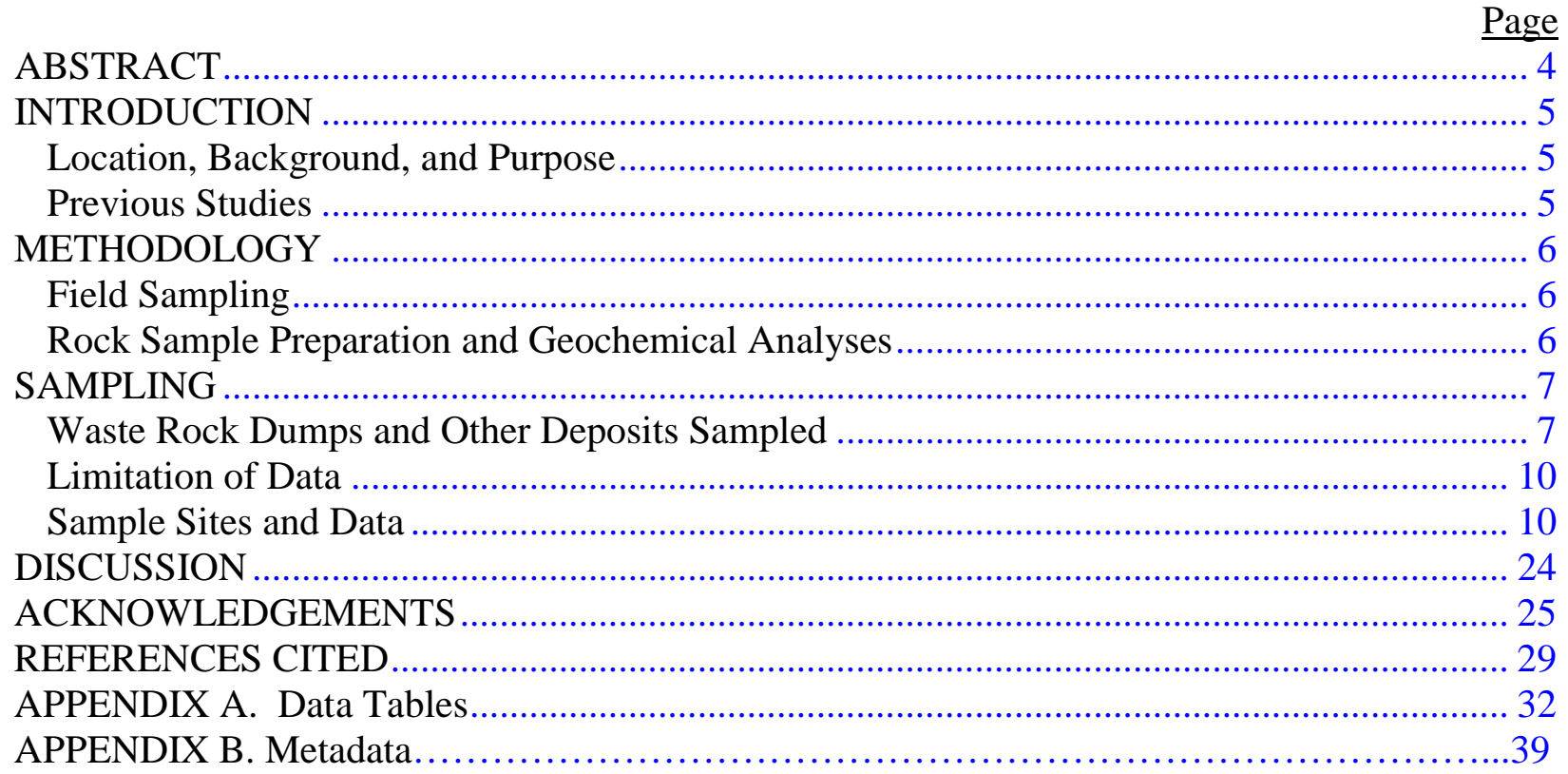

\section{FIGURES}

1. View west of Dry Valley mine showing waste rock backfill into open pit on right.

2. Various colors and sizes of rock in a complex of waste rock dumps at an active phosphate mine in southeastern Idaho illustrate the heterogeneous lithology and grain size characteristics of dumps.

3. View north of several waste rock dumps at the Waterloo mine near Montpelier, ID.

4. Generalized map of southeast Idaho, western Wyoming, and northern Utah showing phosphate sample sites, selected sample numbers, and locations of figures 5 and 6.

5. Generalized map of phosphate mines in southeastern Idaho showing selected sample sites and location of figure 6.

6. Map of selected phosphate mines in the Blackfoot River watershed, Caribou County, Idaho, showing sample sites.

7. View north of the Wooley Valley mine waste rock dump at Unit I, Caribou County, Idaho, sample site WPD2017C.

8. View south of the Wooley Valley mine waste rock dump at Unit IV, Caribou County, Idaho, sample sites WPD2019C-23C.

9. View west of the Ballard mine and waste rock dumps, Caribou County, Idaho, sample site WPD2005C.

10. View northeast of a waste rock dump at the Henry mine, central, Caribou County, Idaho, sample site WPD2018C.

11. View north of a waste rock dump at the Woodall Mountain mine, Caribou County, Idaho, sample site WPD2024C.

12. View south of the Champ-Champ Extension mine, Caribou County, Idaho, sample site WPD2001C.

13. View west of reclaimed waste rock dump at the Mountain Fuel mine, Caribou County, Idaho, sample site WPD2002C. 
14. View southwest of partially-reclaimed waste rock dump on the west side of the Mountain Fuel mine, Caribou County, Idaho, sample site WPD2003C.

15. View south of Georgetown mine, Bear Lake County, Idaho, processing plant near sample site WPQ2028C.

16. View north of Church Hollow tailings near Georgetown Canyon mine, Bear Lake County, Idaho, sample site WPD2029C.

17. View north of waste rock dumps at the Waterloo mine, Bear Lake County, Idaho, sample sites WPD2030C (dark rock) and WPD2031C (light rock).

18. View southwest of sample site at Hot Springs mine, Bear Lake County, Idaho; showing sample WPQ2013C cut along line.

19. View northwest of waste rock dump at Little Diamond Creek mine, Utah County, Utah, showing sample site WPD2009C.

20. View north of waste rock dumps at Cokeville mine, Lincoln County, Wyoming, showing sample site WPD2011C.

21. View north of adits and dumps at Raymond Creek mine, Lincoln County, Wyoming. Sample WPD2014C collected from waste rock dump in area from which photograph is taken.

22. View west toward waste rock dump sampled at South Mountain mine, Lincoln County, Wyoming, showing sample site WPD2012C.

23a. Range and average concentrations of selected elements for all 31 samples analyzed.

23b. Range and average concentrations of selected elements for 25 waste-rock dump samples analyzed.

24. Graph of average concentration of selected elements for 25 waste-rock dump samples normalized to the average abundance of the elements in average world-wide shales.

\section{TABLES}

1. List of phosphate mine sites sampled showing mine type, feature sampled, lithology, and sample type.

2. Average, maximum, and minimum concentrations for selected individual and ICP-40 analytes for the 25 samples from waste-rock dumps and for all 31 samples, and average abundance of elements in shale.

A-1. Sample descriptions and locations.

A-2. Individual and ICP-10 analyses.

A-3. ICP-16 analyses.

A-4. ICP-40 analyses. 


\begin{abstract}
This report provides chemical analyses for 31 samples collected from various phosphate mine sites in southeastern Idaho (25), northern Utah (2), and western Wyoming (4). The sampling effort was undertaken as a reconnaissance and does not constitute a characterization of mine wastes. Twenty-five samples were collected from waste rock dumps, 2 from stockpiles, and 1 each from slag, tailings, mill shale, and an outcrop. All samples were analyzed for a suite of major, minor, and trace elements. Although the analytical data set for the 31 samples is too small for detailed statistical analysis, a summary of general observations is made.

Element concentrations vary considerably because of the differing rock types collected over a wide geographic area. For the 25 waste rock dump samples, concentrations of arsenic, antimony, thallium, chromium, copper, nickel, and vanadium are moderately elevated, ranging from 1.5 to 5.6 times those of average world-wide shale, the average concentrations of four elements are significantly elevated compared to their average abundance in average world-wide shale selenium (x 77), cadmium (x 172), molybdenum (x 19), and zinc (x 12). A sample of slag, a product of high-temperature processing, collected from an inactive elemental phosphorus plant at the Georgetown Canyon mine contains the highest concentrations for 17 elements - silver, cobalt, chromium, copper, europium, iron, gallium, manganese, molybdenum, niobium, nickel, phosphorus, thorium, titanium, vanadium, ytterbium, and zirconium - and the lowest concentrations for 17 others - aluminum, carbon, calcium, cadmium, mercury, potassium, lanthanum, lithium, magnesium, sodium, sulfur, scandium, selenium, strontium, thallium, yttrium, and zinc. Highly contrasting geochemical signatures occur for two samples collected from the same waste-rock dump at the Waterloo mine near Montpelier, ID illustrating the heterogeneous nature waste dump rocks.
\end{abstract}




\section{INTRODUCTION}

\section{Location, Background, and Purpose}

The U.S. Geological Survey (USGS) has studied the Permian Phosphoria Formation and related rock units in southeastern Idaho and the Western Phosphate Field throughout much of the twentieth century. In response to a request by the Bureau of Land Management (BLM), a new series of resource, geological, and geoenvironmental studies were initiated by the USGS in 1998. Present studies consist of integrated, multidisciplinary research directed toward (1) resource and reserve estimation of phosphate in selected 7.5-minute quadrangles; (2) element residence, mineralogical, and petrochemical characteristics; (3) mobilization and reaction pathways, transport, and fate of potentially toxic elements associated with the occurrence, development, and societal use of phosphate; (4) geophysical signatures; and (5) improving understanding of depositional environments. To carry out these studies, the USGS is conducting collaborative research with the BLM and the U.S. Forest Service (FS), which are responsible for land management and resource conservation on public lands, and with five companies currently leasing or developing phosphate resources in southeast Idaho: Agrium U.S. Inc. (Rasmussen Ridge mine), Astaris LLC (Dry Valley mine), J.R. Simplot Company (Smoky Canyon mine), Rhodia Inc. (Wooley Valley mine - inactive), and Monsanto (Enoch Valley mine). Because raw data acquired during the project require time to interpret, the data are released in open-file reports for prompt availability to other scientists. Open-file reports associated with this series of resource and geoenvironmental studies are submitted to the Federal and industry collaborators for comment; however, the USGS is solely responsible for the content of the reports.

Limited sampling of phosphate mine wastes and other deposits at selected active and historic phosphate mines in southeastern Idaho, western Wyoming, and northern Utah was completed in support of on-going geologic mapping, remote sensing, and phosphate resource studies. These data, together with related sampling and chemical analyses of rock outcrops, exposed sections at active mines, and archived samples from previous studies, will contribute to an overall effort to characterize the spatial distribution of selenium and other trace elements throughout the Western Phosphate Field, both in situ and in waste piles. Analyses of samples of outcrops and exposed sections will contribute to developing a model of trace element distribution either associated with original deposition or as a result of post-depositional diagenetic or weathering processes. Analyses of mine wastes will contribute to understanding the source characteristics and mobilization of trace elements. The samples and analyses described in this report are a reconnaissance and do not constitute a characterization of mine wastes.

\section{Previous Studies}

A considerable body of knowledge on the Phosphoria Formation and related rock units in the Western Phosphate Field has been published by scientists of the USGS as well as from others. The historic literature is too large to list; however, mention of selected references is warranted. Pioneering workers such as Mansfield (1918, 1920, 1927, 1933), McKelvey and others (1953a, 1953b, 1959, 1967), Sheldon (1963, 1989), Service and Popoff (1964), Service (1966, 1967), and Gulbrandsen and Krier (1980), concentrated predominantly on delineation and evaluation of phosphate resources and on deposit origin. Research in recent decades has produced significant 
literature by Gulbrandsen (1966), Piper (1974), Desborough (1977), Altschuler (1980) and others on the unusual chemistry of the Meade Peak Phosphatic Shale Member, the primary source of phosphate ore. Phosphate deposit origin, demand, and commodity studies are reported in Herring (1995), Herring and Fantel (1993), and Herring and Stowasser (1991).

Current studies by the USGS have produced numerous reports relevant to the geochemistry of the Phosphoria Formation, particularly the Meade Peak Phosphate Shale Member in southeastern Idaho (Desborough and others, 1999; 2000; Herring and others, 1999a, b, c; 2000a, b, c; Grauch and others, 1999, 2000a, b; and Piper, 1999a, b. A detailed history of phosphate mining in southeastern Idaho was recently completed by Lee (2001). In addition, a spatially registered description of selected phosphate mines in southeastern Idaho, showing mine pits, waste dumps, tailings and other phosphate-mining-related features, has been prepared (Causey and Moyle, 2001). Mine waste samples described in this report were collected during field reconnaissance at several of the mines included in the geospatial database.

\section{Field Sampling}

\section{METHODOLOGY}

Thirty-one samples collected for geochemical analysis were obtained from waste rock dumps (25), stockpiles or mill shale piles (3), tailings (1), slag (1), and outcrop (1) from 20 mines and prospects. Waste rock dump, stockpiles or mill shales, and tailings samples were collected as composite grab samples. Composite grab samples consist of rock material collected from two or more 0.3 - to 0.6 -m-deep holes excavated into the waste rock dump, stockpile, or tailings impoundment and combined into a single composite sample. A sample of slag was "selected" from a heterogeneous mix of mine wastes, processing byproducts and alluvium at a mine-plant complex, and a continuous "chip channel" sample was obtained from an outcrop of Meade Peak member at one inactive mine site. Approximately 2.5 to $5 \mathrm{~kg}$ of rock was collected at each sample locality. Samples were shipped to the laboratory of the USGS in Denver, Colorado for sample preparation.

\section{Rock Sample Preparation and Geochemical Analyses ${ }^{3}$}

Rock samples were air-dried followed by disaggregation in a mechanical jaw crusher. A split was ground to $<100$ mesh $(0.15 \mathrm{~mm})$ in a ceramic plate grinder. A riffle splitter was used to obtain splits to ensure similarity with the whole sample. One set of splits for all samples was archived, and approximately 50-g splits of ground material was shipped to the contract laboratory for analysis.

Forty major, minor, and trace elements were determined for all 31 samples by inductively coupled plasma-atomic emission spectrometry (ICP-AES), also referred to as the ICP-40

\footnotetext{
${ }^{3}$ Aluminum (Al), antimony ( $\mathrm{Sb}$ ), arsenic (As), barium (Ba), beryllium (Be), bismuth (Bi), cadmium (Cd), calcium $(\mathrm{Ca})$, carbon $(\mathrm{C})$, cerium $(\mathrm{Ce})$, chromium $(\mathrm{Cr})$, cobalt $(\mathrm{Co})$, copper $(\mathrm{Cu})$, europium $(\mathrm{Eu})$, gallium $(\mathrm{Ga})$, gold $(\mathrm{Au})$, holmium $(\mathrm{Ho})$, iron $(\mathrm{Fe})$, lanthanum $(\mathrm{La})$, lead $(\mathrm{Pb})$, lithium $(\mathrm{Li})$, magnesium $(\mathrm{Mg})$, manganese $(\mathrm{Mn})$, mercury $(\mathrm{Hg})$, molybdenum (Mo), neodymium $(\mathrm{Nd})$, niobium $(\mathrm{Nb})$, nickel $(\mathrm{Ni})$, phosphorus $(\mathrm{P})$, potassium $(\mathrm{K})$, scandium $(\mathrm{Sc})$, selenium $(\mathrm{Se})$, silicon $(\mathrm{Si})$, silver $(\mathrm{Ag})$, sodium $(\mathrm{Na})$, strontium $(\mathrm{Sr})$, sulfur $(\mathrm{S})$, tantalum $(\mathrm{Ta})$, tellurium $(\mathrm{Te})$, tin $(\mathrm{Sn})$, thallium $(\mathrm{Tl})$, thorium $(\mathrm{Th})$, titanium $(\mathrm{Ti})$, uranium $(\mathrm{U})$, vanadium $(\mathrm{V})$, ytterbium $(\mathrm{Yb})$, yttrium $(\mathrm{Y})$, zinc $(\mathrm{Zn})$, zirconium $(\mathrm{Zr})$.
} 
package, after low-temperature $\left(<150^{\circ} \mathrm{C}\right)$ digestion using concentrated hydrochloric, hydrofluoric, nitric, and perchloric acids (Crock and others, 1983). Splits of all samples were also submitted to the contract laboratory for analysis of 16 major, minor, and trace elements (Al, $\mathrm{Ba}, \mathrm{Ca}, \mathrm{Cr}, \mathrm{Fe}, \mathrm{Mg}, \mathrm{Mn}, \mathrm{Nb}, \mathrm{P}, \mathrm{K}, \mathrm{Si}, \mathrm{Na}, \mathrm{Sr}, \mathrm{Ti}, \mathrm{Y}, \mathrm{Zr}$ ) by ICP-AES using a lithium metaborate fusion. This technique is also referred to as the ICP-16 package. The samples were fused with lithium metaborate in a graphite crucible. In-house standards were run to monitor the proper digestion procedure, and synthetic standards were used to calibrate the instrument. Sample solutions were aspirated into the ICP through a high-solids nebulizer, and metal concentrations were measured simultaneously. Eight samples were also submitted for a 10-element ICP-AES technique, also referred to as ICP-10, for determination of $\mathrm{Ag}, \mathrm{As}, \mathrm{Au}, \mathrm{Bi}, \mathrm{Cd}, \mathrm{Cu}, \mathrm{Mo}, \mathrm{Pb}, \mathrm{Sb}$, and $\mathrm{Zn}$. Hydrochloric acid and hydrogen peroxide were used to solubilize metals not tightly bound in the silicate lattice of rocks. Metals are extracted as organic halides. Concentrations of the extracted metals were determined simultaneously after aspiration into a multichannel ICP instrument. This procedure is a partial digestion and results may be biased low when compared to procedures involving complete dissolution of the sample.

Sample splits were also submitted for individual analysis of ten elements or compounds by specific methods. Arsenic, Sb, Se, Tl and Te analyses were performed by hydride generationatomic absorption spectrometry. $\mathrm{Hg}$ was analyzed by cold vapor-atomic absorption spectrometry. Total $\mathrm{S}$ and total $\mathrm{C}$ were analyzed by combustion in an oxygen atmosphere followed by infrared measurement of evolved $\mathrm{CO}_{2}$ and $\mathrm{SO}_{2}$. Carbonate (inorganic) $\mathrm{C}$ was determined by coulometric titration after acidification. An interim value for $\mathrm{CO}_{2}$ is also reported. Organic $\mathrm{C}$ may be calculated as the difference between total and carbonate carbon.

\section{SAMPLING}

\section{Waste Rock Dumps and Other Deposits Sampled}

Generally located close to the mine to reduce haulage costs, a waste rock dump is composed of heterogeneous mine waste materials excavated from underground or surface workings for the purpose of exposing and excavating ore. The Bureau of Mines (1968) dictionary defines waste rock as "barren or submarginal rock or ore which has been mined but is not of sufficient value to warrant treatment and is therefore removed ahead of the milling process" and a waste dump as "the area where mine waste or spoil materials are disposed of or piled." Typically, waste rock may be placed on hillsides, in valleys or ravines, or on any convenient surface that provides long-term stability. Modern open-pit operations often backfill waste rock into the mine pit to return the surface as close as possible to the original landform and to minimize exposure of waste rock to surface weathering processes (figure 1). Waste rock dumps range in size (volume) from a few hundred to a thousand cubic meters, typical of smaller underground mines, to tens of millions of cubic meters at large, open-pit mines. Ore is often placed into temporary piles or impoundments called stockpiles until it is ready for transport or processing. Mill shales consist of subeconomic phosphatic rock, generally 14 to $<18$ percent $\mathrm{P}_{2} \mathrm{O}_{5}$, stockpiled for possible future use. Tailings are fine-grained waste materials from milling (crushing and grinding) and other processes. Tailings have generally been subjected to both mechanical and chemical processes that result in fundamental changes in their chemical and physical characteristics. Slag is the waste product of a process that subjects ore to high temperatures to recover a desirable product 
such as phosphorus. Molten slag is periodically removed, tapped, from electric arc furnaces at temperatures ranging from $1450^{\circ}$ to $1550^{\circ} \mathrm{C}$ (Van Wazer, 1961). Slag is typically fused and is also altered chemically from the original rock composition.

Phosphate mine waste rock dumps may consist of a range of materials or lithologies including overburden (unconsolidated surficial material), overlying strata such as Rex Chert, low-grade material from portions of the Meade Peak member, such as center waste shale, underlying strata such as the Wells Formation, or any other materials associated with the mine site (figure 2). At large, open-pit phosphate mines typical of modern operations, a single mine may have several waste rock dumps, each composed of a unique assemblage of rock types (figure 3 ).

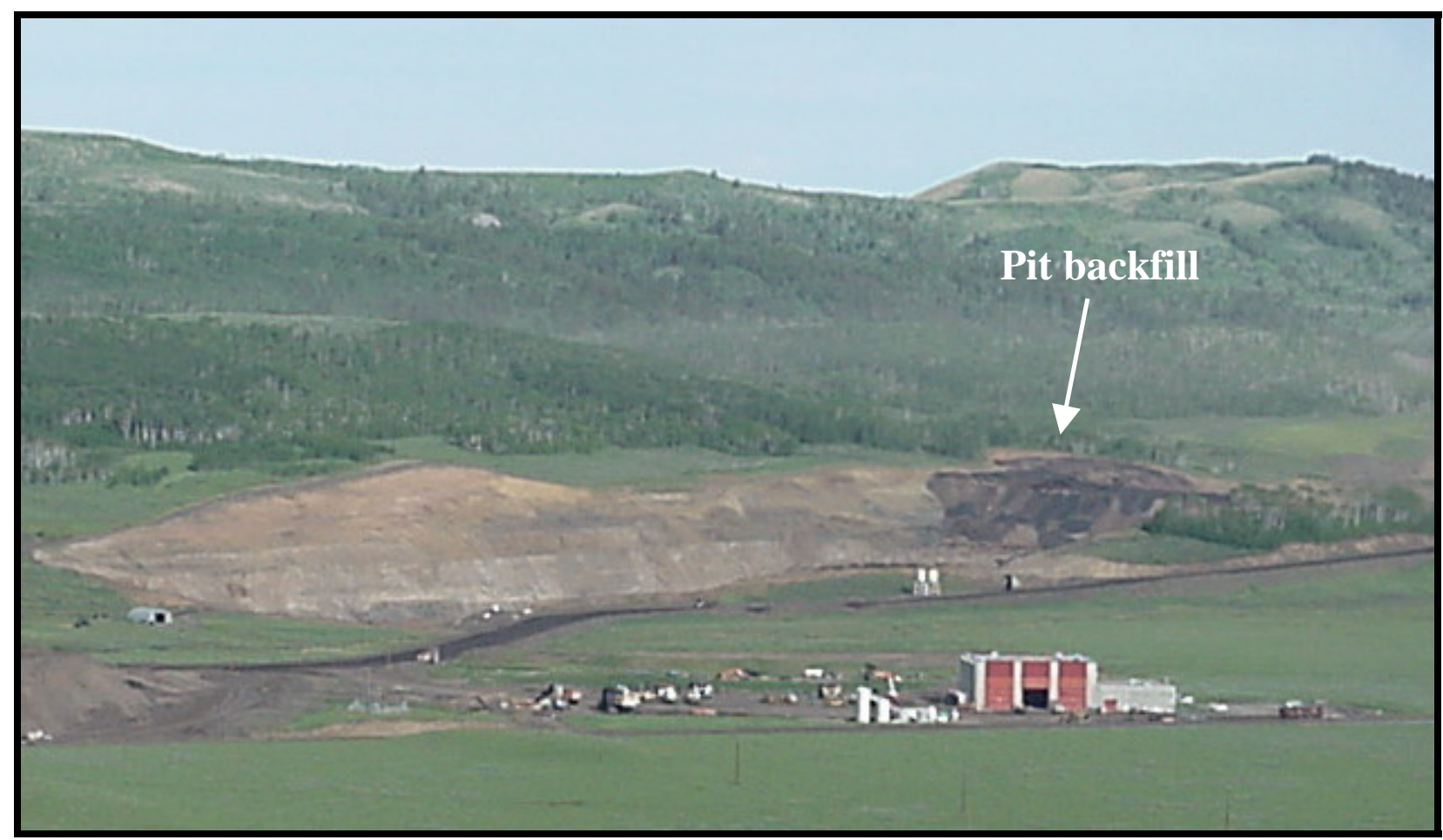

Figure 1. View west of Dry Valley mine showing waste rock backfill into open pit on right.

Waste rock dumps are heterogeneous in both grain size and structure. The rock fragments in a dump are a product of mechanical processes, such as drilling, blasting, and ripping, designed to disaggregate a massive body of in-place rock in order to excavate and transport the materials. Consequently, dump rock may range in size from clay particles to boulders (e.g. less than 0.1 $\mathrm{mm}$ to greater than $1 \mathrm{~m}$ in diameter). Natural gravity sorting of rock poured from a haulage truck onto a waste dump face may result in a vertical size distribution, finer materials tend to remain near the top and coarse materials tend to roll down the face toward the toe of the dump (figure 2). 


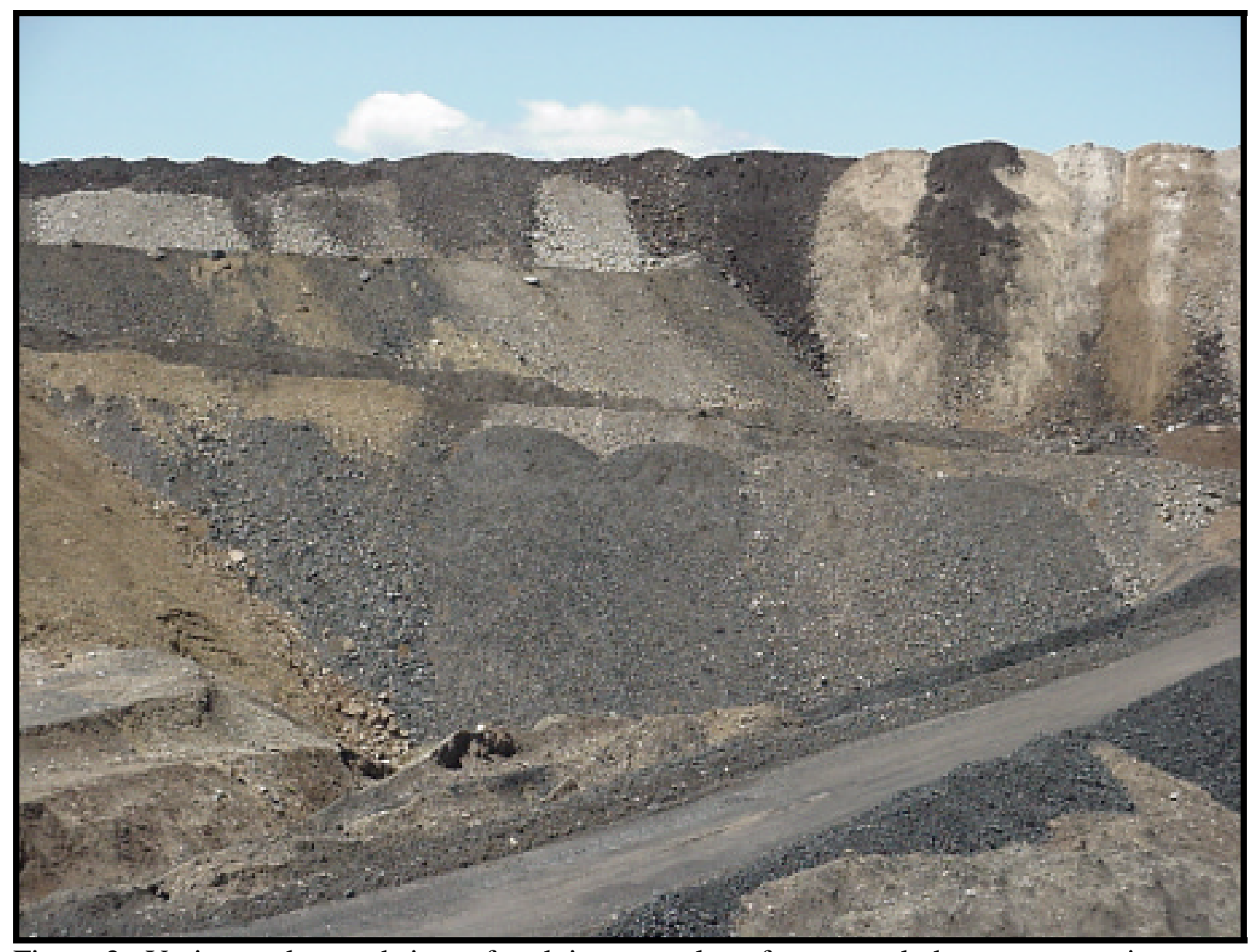

Figure 2. Various colors and sizes of rock in a complex of waste rock dumps at an active phosphate mine in southeastern Idaho illustrate the heterogeneous lithology and grain size characteristics of dumps. Note the high incidence of coarse rock near the toe of the dumps.

The manner in which a waste rock dump is designed and constructed can also result in significant differences in structure. Commonly, construction of a dump progresses by addition of material to the top of the dump at the face, allowing waste rock to form a continuously renewed veneer on the face. The dump progresses outward horizontally as successive layers are added to the face. However, some dumps are engineered in other ways, resulting in significantly different internal structures. For instance, in order to enhance dump stability and to minimize the release of fine sediment into the down-stream environment, some dumps have been designed with a French drain, a layer of coarse, durable rock, such as chert, placed at the base to allow unrestricted flow of a stream through the base of the dump. At other locations, waste rock dumps have been constructed in layers or raises resulting in a sequence or stack of dumps. 


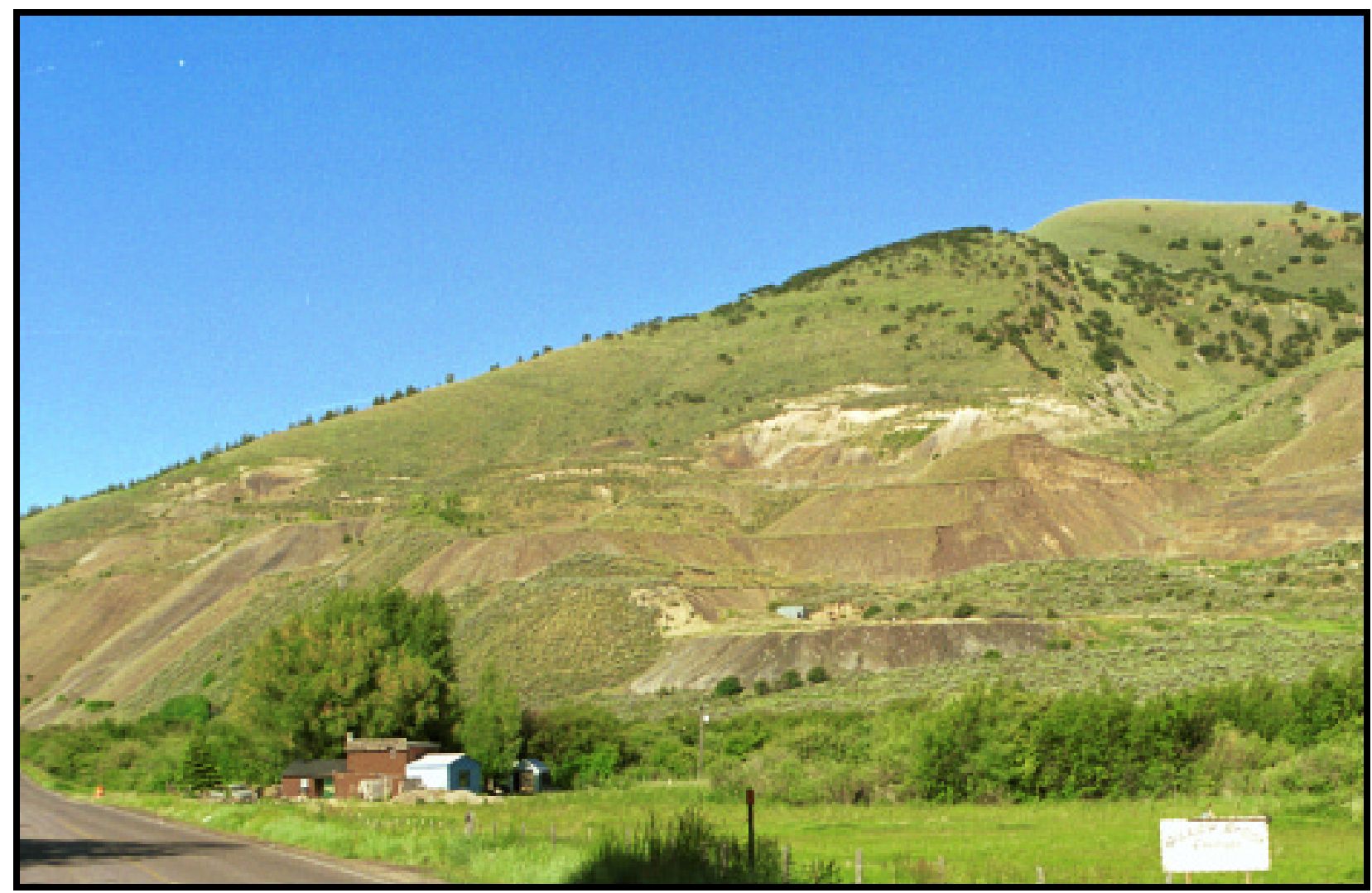

Figure 3. View north of several waste rock dumps at the Waterloo mine near Montpelier, ID.

\section{Limitation of Data}

As noted in the introduction, studies of mine wastes may contribute to understanding the source characteristics, mobilization, and transport of trace elements of concern; however, the sampling and analyses described here are reconnaissance in nature. Clearly, every dump constitutes a unique set of physical and chemical conditions, and one or two samples collected from the surface, or near surface, are not representative. Consequently, the data presented here do not constitute a characterization of mine wastes nor are the data considered to be representative of any of the mine sites investigated.

\section{Sample Sites and Data}

The region studied includes portions of Idaho, Utah, and Wyoming (figure 4 and table 1) where 31 samples were collected from 20 mines and prospects. Twenty-five samples were collected in southeastern Idaho (figures 5-18), two in northern Utah (figures 4 and 19), and four in western Wyoming (figures 4 and 20-22). Of the samples, 25 were collected from waste rock dumps, 2 from stockpiles, and one each of a mill shale pile, tailings (figure 16), slag (figure 15), and an outcrop (figure 18). Mine names, sample locations, sample types and methods, and brief lithologic descriptions are listed in Table 1, and detailed sample information and geochemical analyses for the 31 samples collected are presented in Appendix tables A-1, A-2, A-3, and A-4. Federal Geographic Data Committee compliant metadata are listed in Appendix B. 


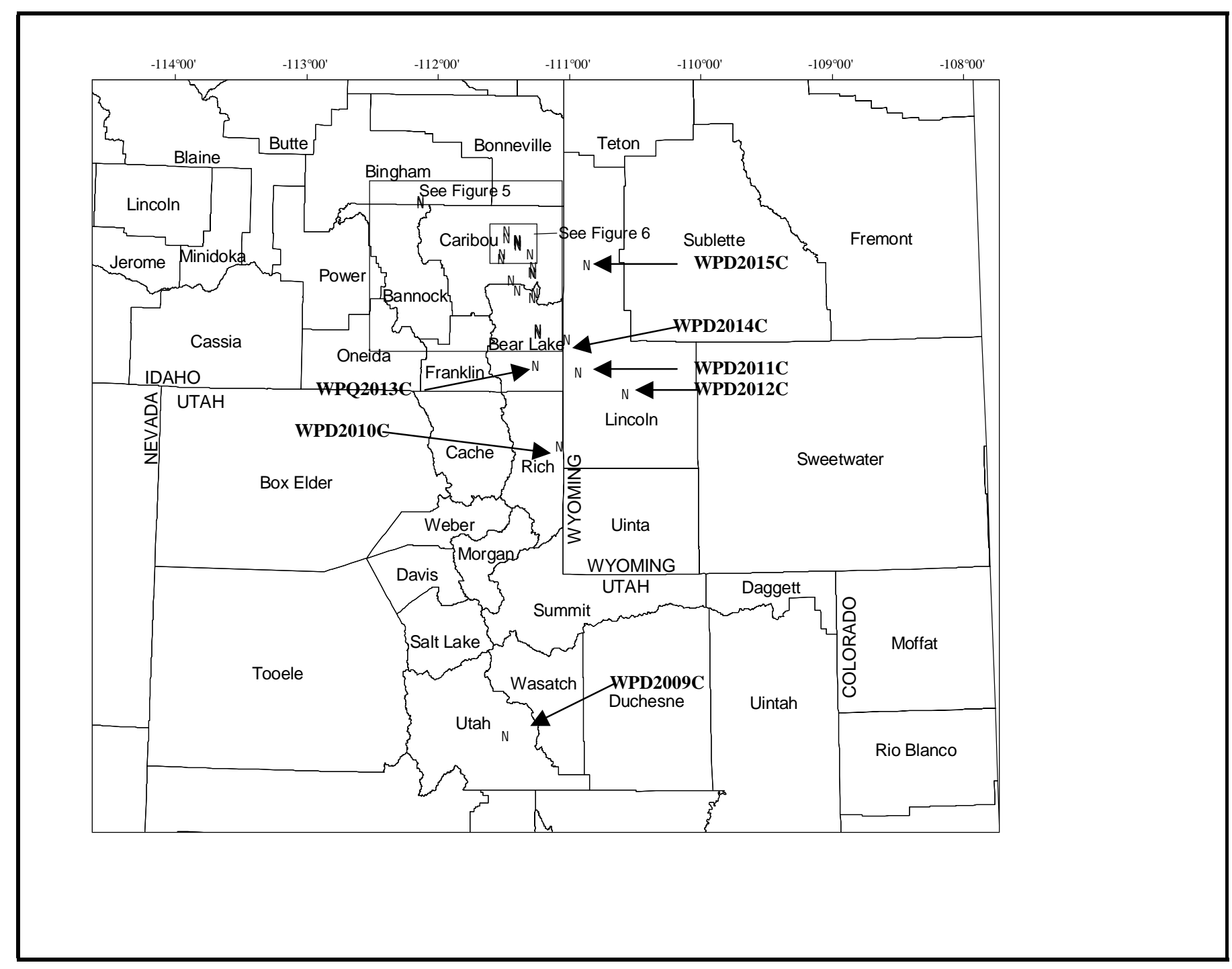

Figure 4. Generalized map of southeast Idaho, western Wyoming, and northern Utah showing phosphate sample sites, selected sample numbers, and locations of figures 5 and 6. 
Table 1. List of phosphate mine sites sampled showing mine type, feature sampled, lithology, and sample type.

\begin{tabular}{|c|c|c|c|c|c|c|c|}
\hline SITE NAME & COUNTY & $\begin{array}{l}\text { MINE } \\
\text { TYPE }\end{array}$ & $\begin{array}{l}\text { FEATURE } \\
\text { SAMPLED }\end{array}$ & LITHOLOGY & $\begin{array}{l}\text { SAMPLE } \\
\text { NUMBER }\end{array}$ & $\begin{array}{l}\text { SAMPLE } \\
\text { TYPE }\end{array}$ & $\begin{array}{c}\text { QUADRANGLE } \\
\text { MAP }\end{array}$ \\
\hline \multicolumn{8}{|c|}{ IDAHO } \\
\hline Ballard Mine & Caribou & open pit & waste dump & shale & WPD2005C & composite & Lower Valley \\
\hline Champ Mine & Caribou & open pit & waste dump & black shale \& limestone & WPD2001C & composite & Dry Valley \\
\hline $\begin{array}{l}\text { Conda/Woodall } \\
\text { Mountain Mine }\end{array}$ & Caribou & $\begin{array}{c}\text { open pit \& } \\
\text { UG }\end{array}$ & waste dump & gray-black shale & WPD2024C & composite & Soda Springs \\
\hline$\frac{\text { Conda/Woodall }}{\text { Mountain Mine }}$ & Caribou & $\begin{array}{c}\text { open pit \& } \\
\text { UG }\end{array}$ & waste dump & $\begin{array}{l}\text { tan-brown shale, limestone, } \\
\& \text { pelletal phosphorite }\end{array}$ & WPD2025C & composite & Soda Springs \\
\hline $\begin{array}{l}\text { Diamond Gulch } \\
\text { Mine }\end{array}$ & Caribou & open pit & waste dump & black shale \& limestone & WPD2004C & composite & Fossil Canyon \\
\hline Gay Mine & Bannock & open pit & mill shale pile & gray-black shale & WPQ2026C & composite & Yandell Springs \\
\hline Gay Mine & Bingham & open pit & waste dump & $\begin{array}{c}\text { brown-gray shale \& } \\
\text { limestone }\end{array}$ & WPD2027C & composite & Yandell Springs \\
\hline $\begin{array}{l}\begin{array}{l}\text { Georgetown Mine - } \\
\text { plant }\end{array} \\
\end{array}$ & Bear Lake & open pit & slag pile & gray, metallic & WPQ2028C & select & Harrington Peak \\
\hline $\begin{array}{c}\text { Georgetown } \\
\text { Canyon - Church } \\
\text { Hollow }\end{array}$ & Bear Lake & open pit & tailings & $\begin{array}{c}\text { brownish-gray, fine-grained, } \\
\text { phosphatic shale w/ pea- } \\
\text { sized gravel }\end{array}$ & WPD2029C & composite & Harrington Peak \\
\hline Henry Mine, central & Caribou & open pit & waste dump & gray-black shale & WPD2018C & composite & Lower Valley \\
\hline Home Canyon Mine & Bear Lake & UG & waste dump & black shale & WPD2007C & composite & Montpelier Canyon \\
\hline Home Canyon Mine & Bear Lake & UG & stockpile & phosphorite & WPD2008C & composite & Montpelier Canyon \\
\hline Hot Springs Mine & Bear Lake & $\begin{array}{c}\text { Prospect } \\
\text { Pit }\end{array}$ & outcrop & $\begin{array}{c}\text { flat-lying organic-rich shale \& } \\
\text { phosphorite }\end{array}$ & WPQ2013C & chip (4.5') & Bear Lake North \\
\hline Maybe Canyon adit & Caribou & UG & waste dump & black shale & WPD2006C & composite & Dry Valley \\
\hline Mountain Fuel Mine & Caribou & open pit & waste dump & black shale \& limestone & WPD2002C & composite & Dry Valley \\
\hline Mountain Fuel Mine & Caribou & open pit & waste dump & black shale \& limestone & WPD2003C & composite & Dry Valley \\
\hline \begin{tabular}{|l|} 
Rattlesnake Canyon \\
Mine
\end{tabular} & Bear Lake & UG & waste dump & brown-black shale & WPD2016C & composite & Fossil Canyon \\
\hline
\end{tabular}

$\mathrm{UG}=$ underground workings 
Table 1. List of phosphate mine sites sampled showing mine type, feature sampled, lithology, and sample type. - continued

\begin{tabular}{|c|c|c|c|c|c|c|c|}
\hline SITE NAME & COUNTY & $\begin{array}{l}\text { MINE } \\
\text { TYPE }\end{array}$ & $\begin{array}{l}\text { FEATURE } \\
\text { SAMPLED }\end{array}$ & LITHOLOGY & $\begin{array}{l}\text { SAMPLE } \\
\text { NUMBER }\end{array}$ & $\begin{array}{l}\text { SAMPLE } \\
\text { TYPE }\end{array}$ & $\begin{array}{c}\text { QUADRANGLE } \\
\text { MAP }\end{array}$ \\
\hline \multicolumn{8}{|c|}{ IDAHO (continued) } \\
\hline Waterloo Mine & Bear Lake & $\begin{array}{c}\text { open pit \& } \\
\text { UG }\end{array}$ & waste dump & $\begin{array}{l}\text { dark gray to black } \\
\text { phosphatic shale }\end{array}$ & WPD2030C & composite & Montpelier Canyon \\
\hline Waterloo Mine & Bear Lake & $\begin{array}{c}\text { open pit \& } \\
\text { UG }\end{array}$ & waste dump & $\begin{array}{l}\text { beige-tan fissile sandy shale } \\
\text { and limestone w/ brown- } \\
\text { orange iron oxide stains }\end{array}$ & WPD2031C & composite & Montpelier Canyon \\
\hline $\begin{array}{c}\text { Wooley Valley Mine, } \\
\text { Unit } 1\end{array}$ & Caribou & open pit & waste dump & brown-black shale & WPD2017C & composite & Lower Valley \\
\hline $\begin{array}{c}\text { Wooley Valley Mine, } \\
\text { Unit 4, face level } 5\end{array}$ & Caribou & open pit & waste dump & dark brown shale & WPD2019C & composite & Lower Valley \\
\hline $\begin{array}{l}\text { Wooley Valley Mine, } \\
\text { Unit 4, face level } 4\end{array}$ & Caribou & open pit & waste dump & brown-black shale \& chert & WPD2020C & composite & Lower Valley \\
\hline $\begin{array}{l}\text { Wooley Valley Mine, } \\
\text { Unit 4, face level } 3\end{array}$ & Caribou & open pit & waste dump & brown-black shale \& chert & WPD2021C & composite & Lower Valley \\
\hline $\begin{array}{l}\text { Wooley Valley Mine, } \\
\text { Unit 4, face level } 2\end{array}$ & Caribou & open pit & waste dump & $\begin{array}{l}\text { brown shale, chert, } \\
\text { limestone, \& siltstone }\end{array}$ & WPD2022C & composite & Lower Valley \\
\hline $\begin{array}{l}\text { Wooley Valley Mine, } \\
\text { Unit 4, face level } 1\end{array}$ & Caribou & open pit & waste dump & $\begin{array}{l}\text { gray-brown shale, chert, } \\
\text { siltstone, \& limestone }\end{array}$ & WPD2023C & composite & Lower Valley \\
\hline \multicolumn{8}{|c|}{ UTAH } \\
\hline Benjamin Mine & Rich & UG & waste dump & black shale \& phosphorite & WPD2010C & composite & Rex Peak \\
\hline Little Diamond & Utah & UG & waste dump & black shale \& phosphorite & WPD2009C & composite & Billies Mountain \\
\hline \multicolumn{8}{|c|}{ WYOMING } \\
\hline Cokeville Mine & Lincoln & UG & stockpile & shale \& oolitic phosphorite & WPD2011C & composite & Cokeville \\
\hline $\begin{array}{c}\text { Dry Creek - USBM } \\
\text { adit }\end{array}$ & Lincoln & UG & waste dump & black shale & WPD2015C & composite & Red Top Mountain \\
\hline Raymond Creek & Lincoln & UG & waste dump & black shale & WPD2014C & composite & Geneva \\
\hline $\begin{array}{c}\text { South Mountain } \\
\text { Mine }\end{array}$ & Lincoln & Open Pit & waste dump & black oolitic phosphorite & WPD2012C & composite & Sublet \\
\hline
\end{tabular}

UG = underground workings 


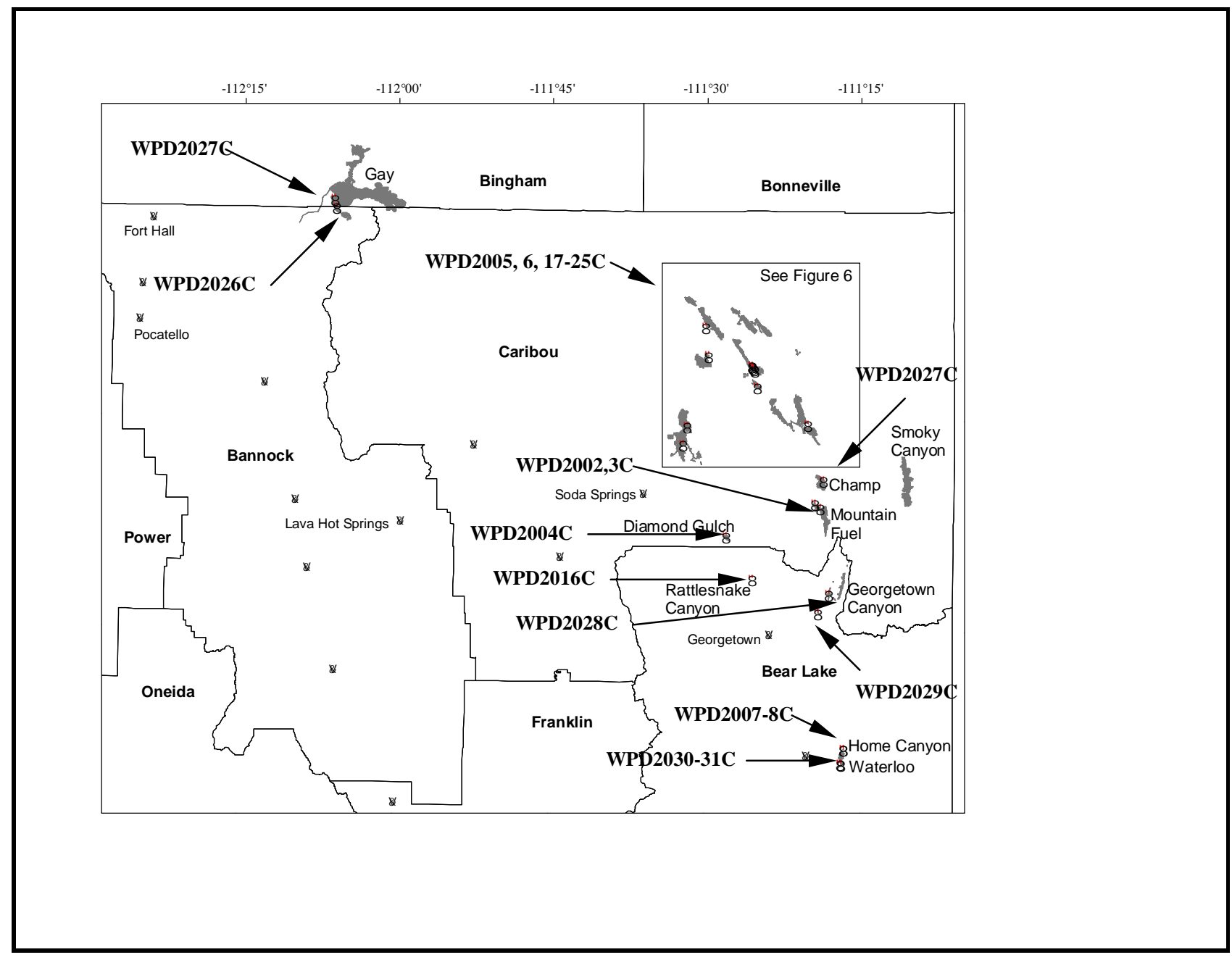

Figure 5. Generalized map of phosphate mines in southeastern Idaho showing selected sample sites and location of figure 6. 


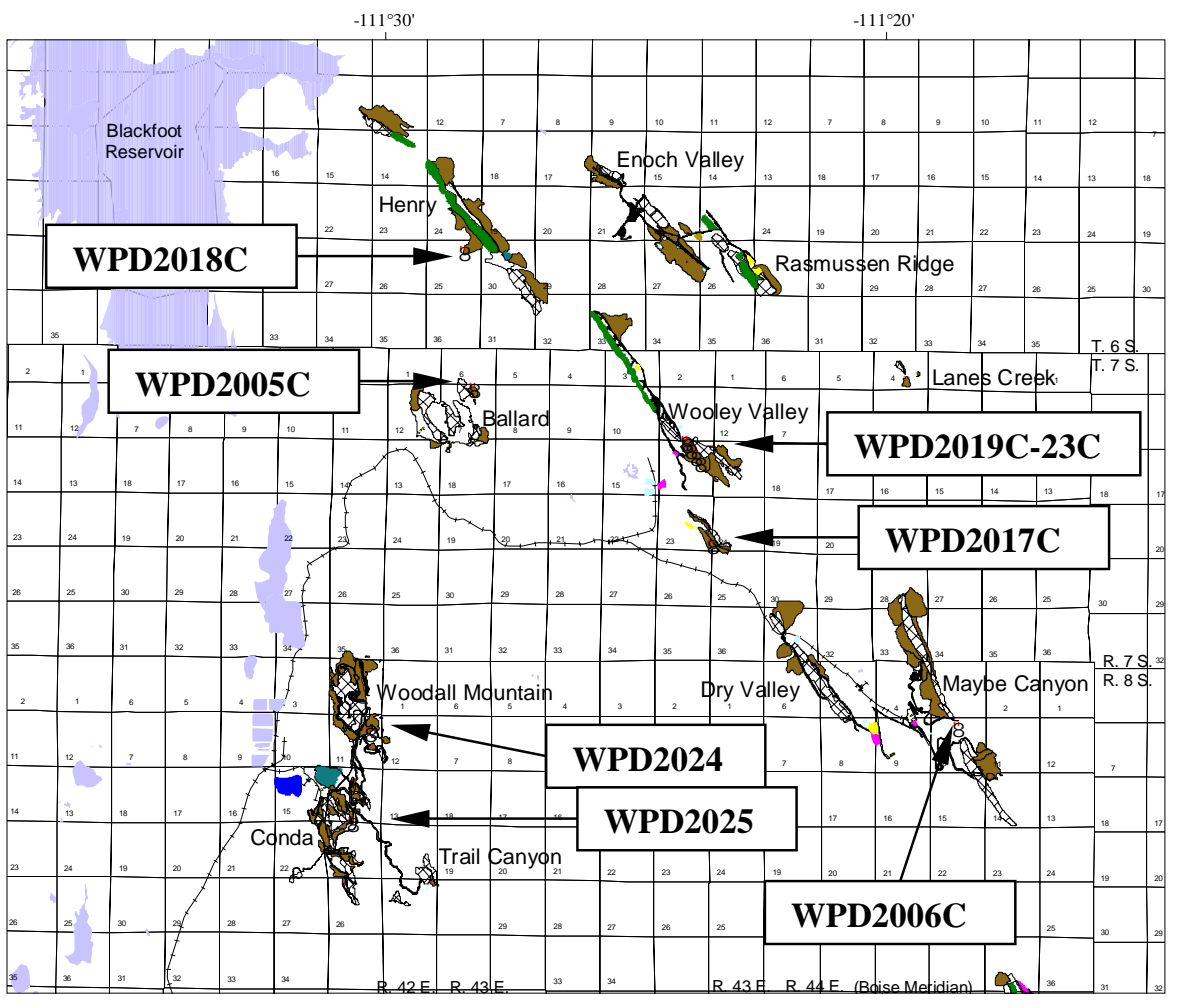

Figure 6. Map of selected phosphate mines in the Blackfoot River watershed, Caribou County, Idaho, showing sample sites. 


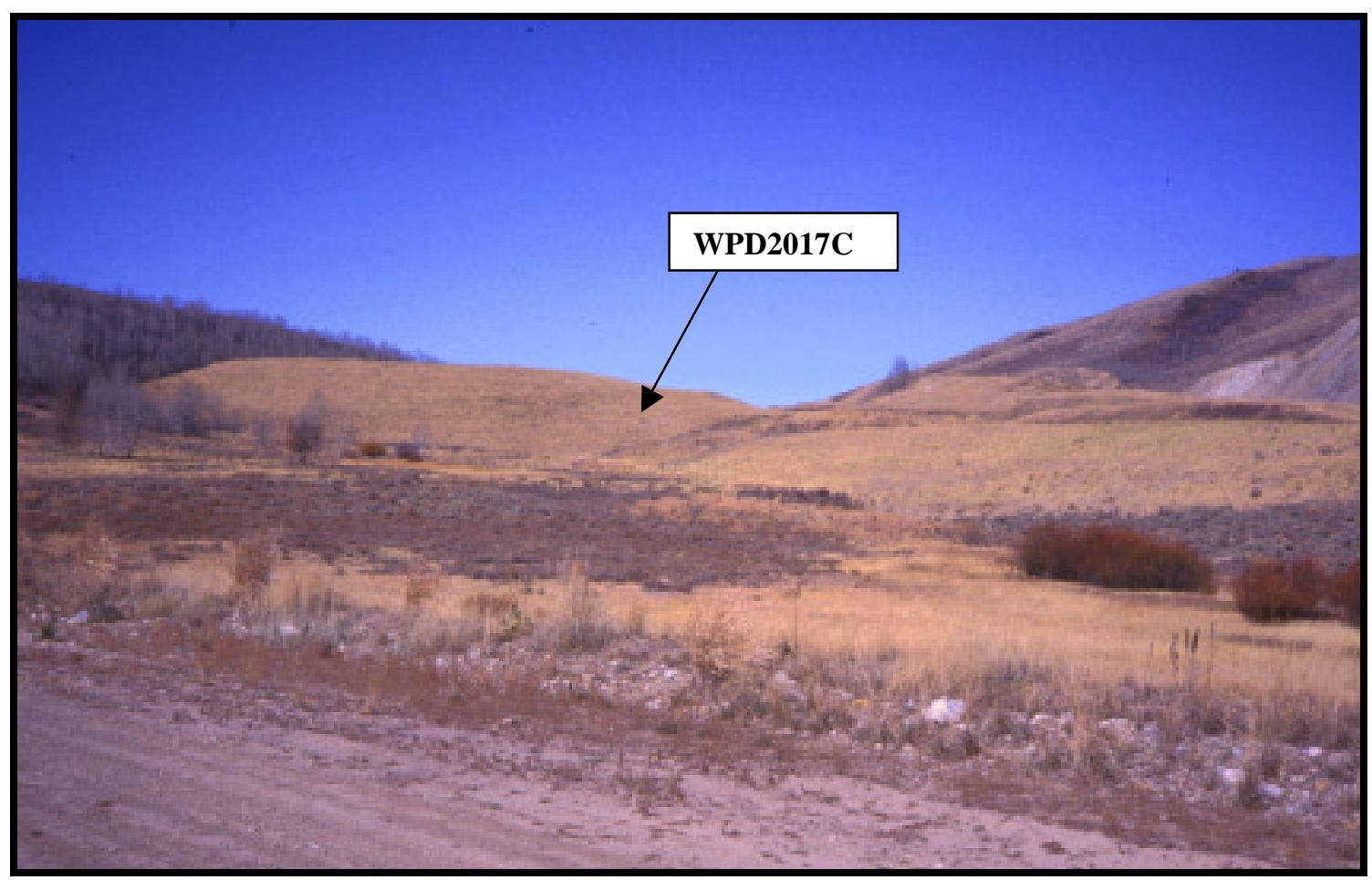

Figure 7. View north of the Wooley Valley mine waste rock dump at Unit I, Caribou County, Idaho, showing sample site WPD2017C.

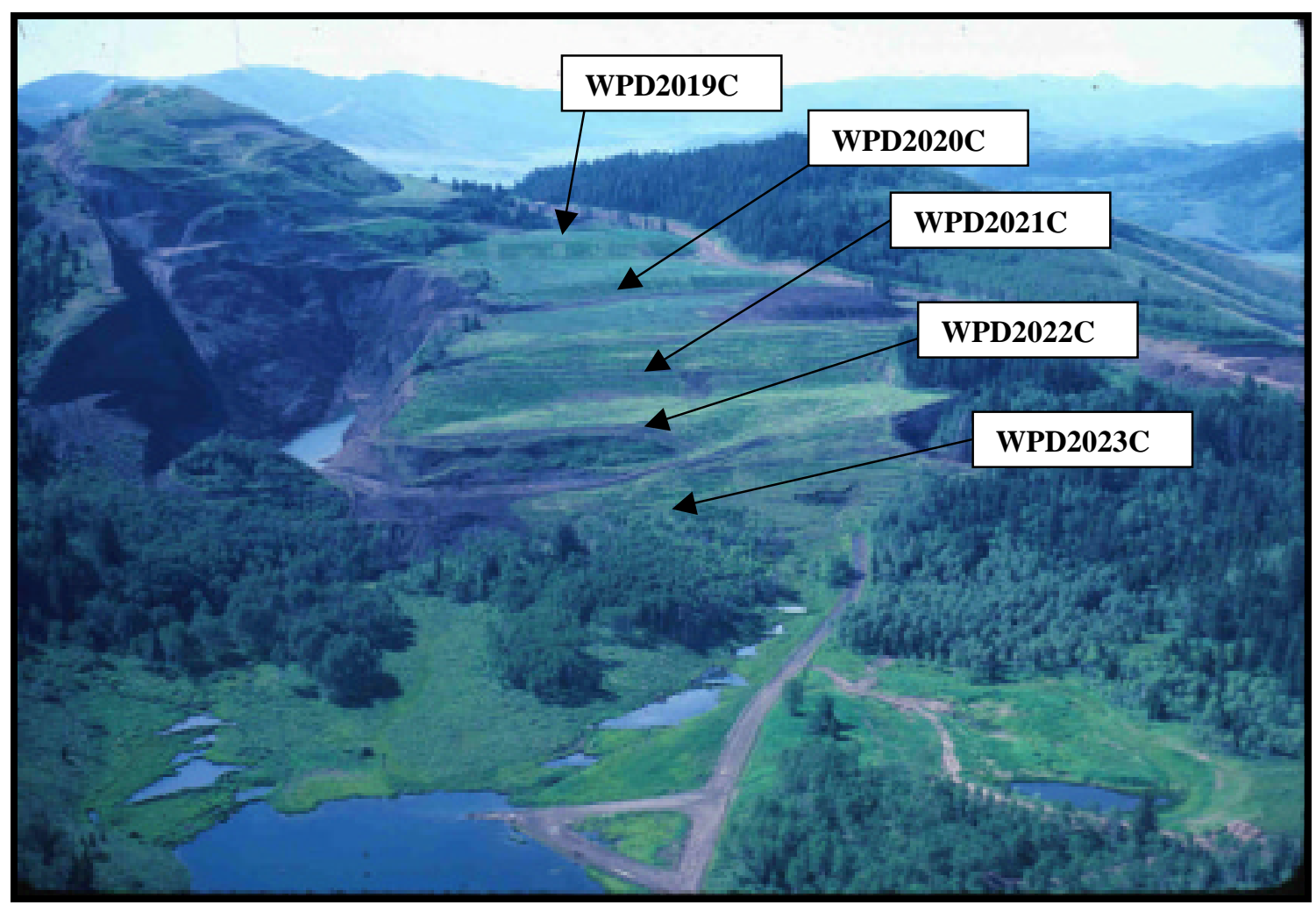

Figure 8. View south of the Wooley Valley mine waste rock dump at Unit IV, Caribou County, Idaho, showing sample sites WPD2019C-23C. 


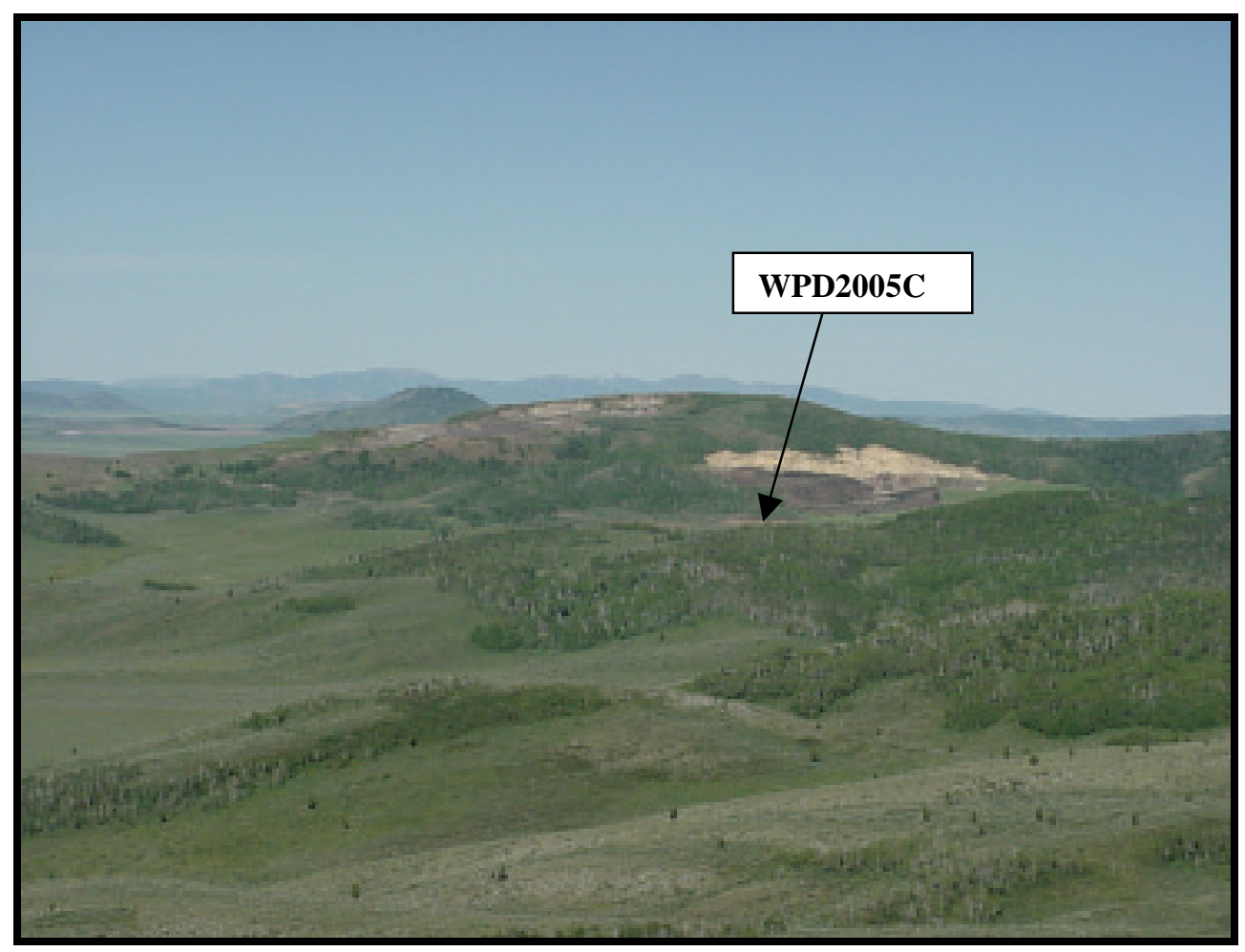

Figure 9. View west of the Ballard mine and waste rock dumps, Caribou County, Idaho, showing sample site WPD2005C.

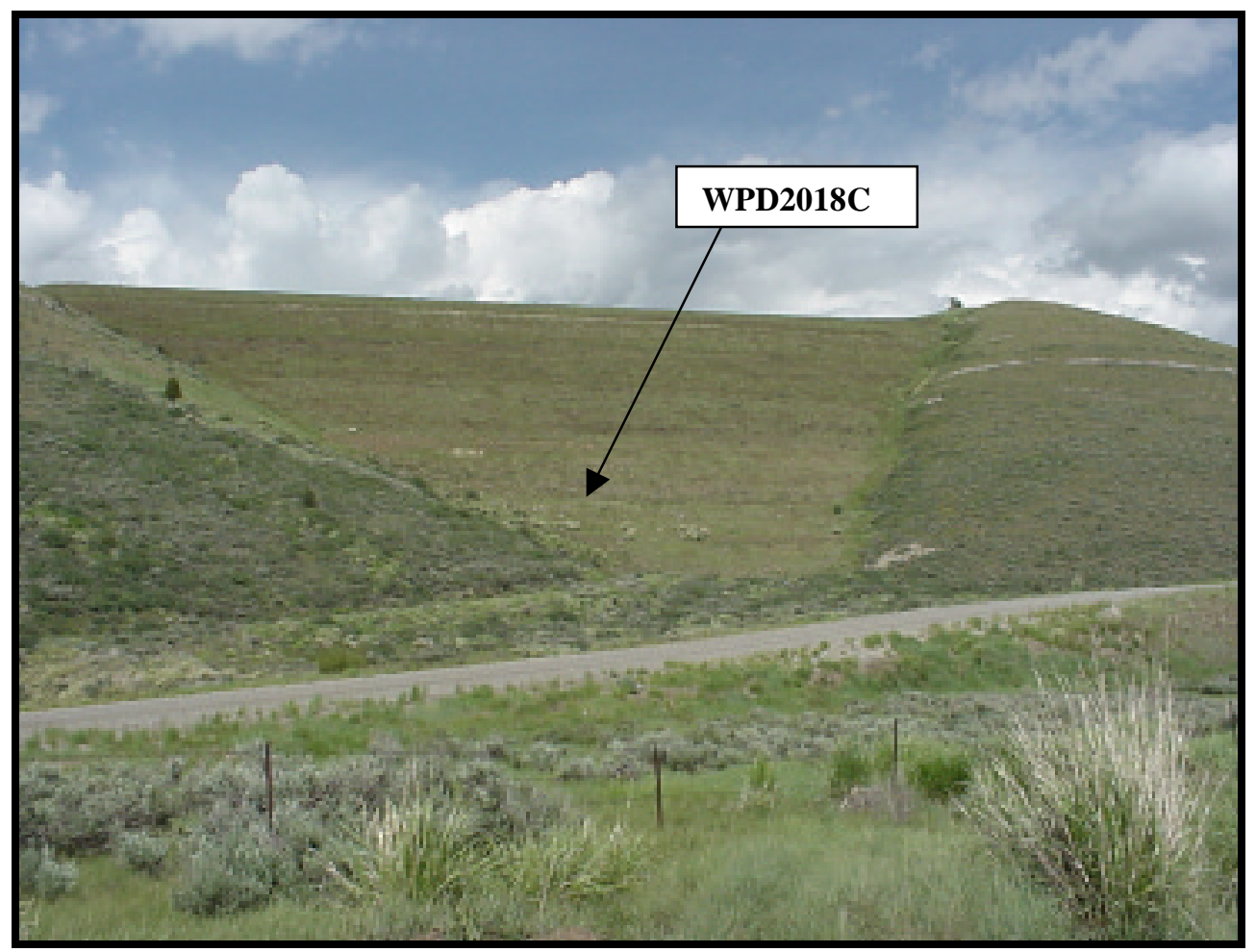

Figure10. View northeast of a waste rock dump at the Henry mine, central, Caribou County, Idaho, showing sample site WPD2018C. 


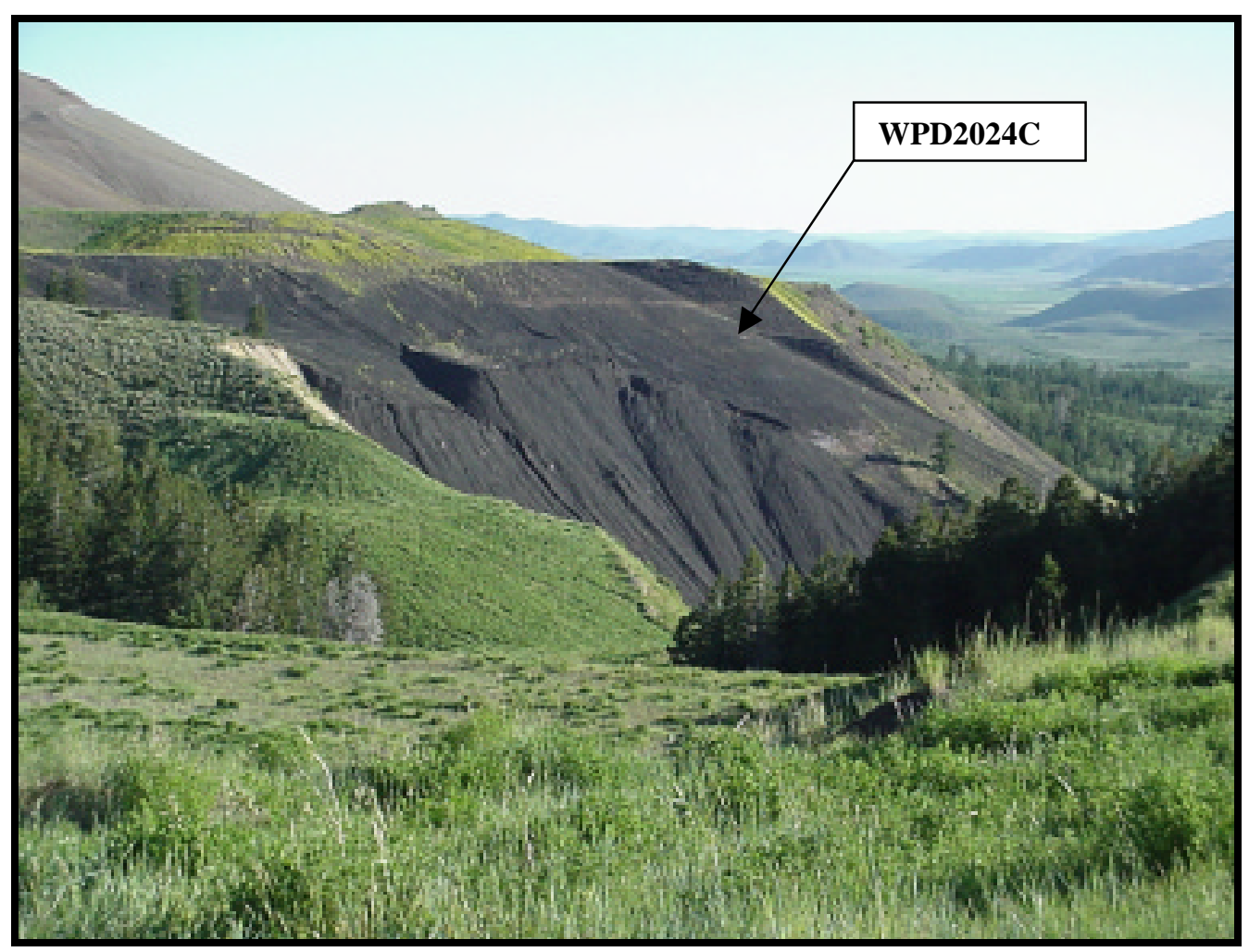

Figure 11. View north of a waste rock dump at the Woodall Mountain mine, Caribou County, Idaho, showing sample site WPD2024C.

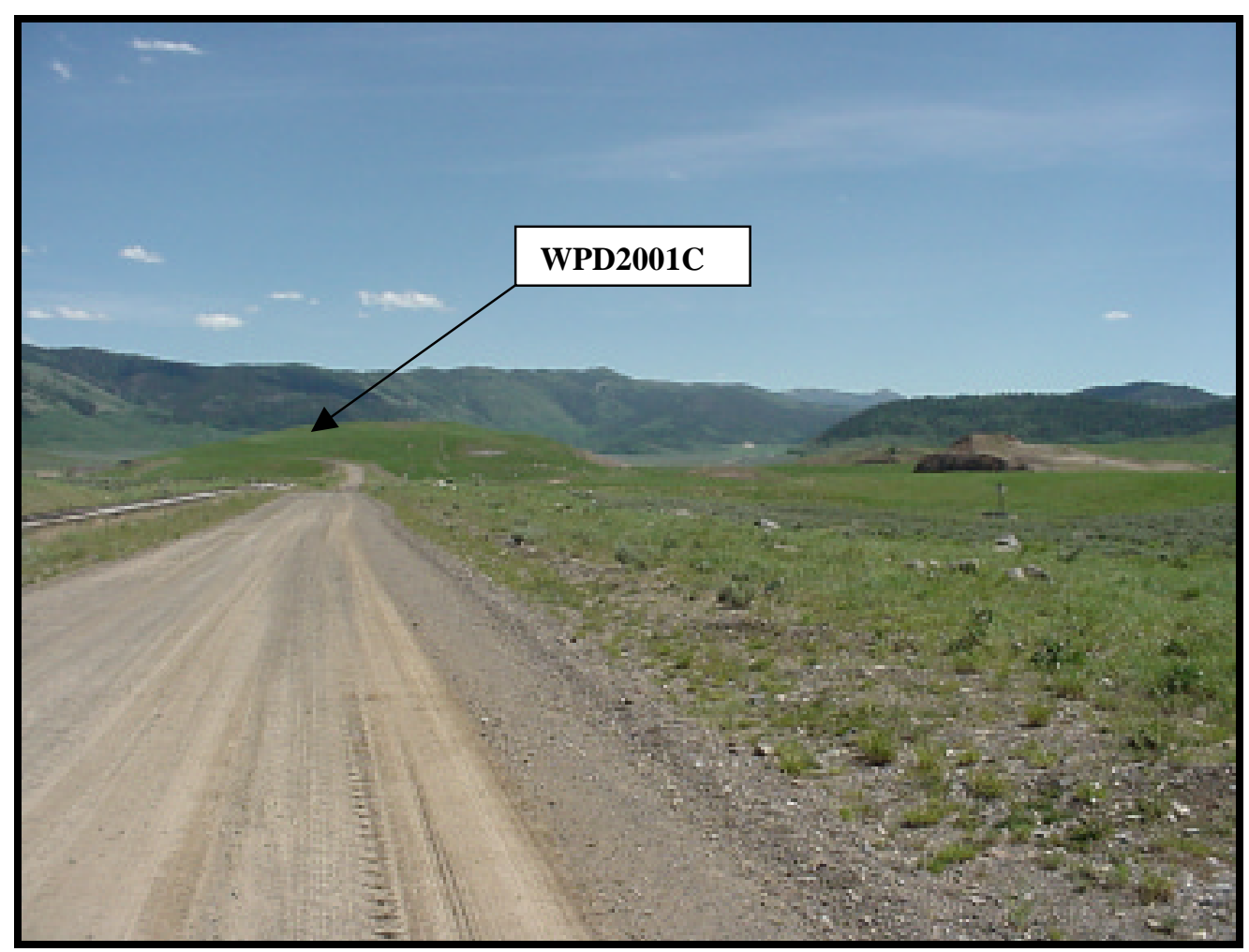

Figure 12. View south of the Champ-Champ Extension mine, Caribou County, Idaho, showing sample site WPD2001C. 


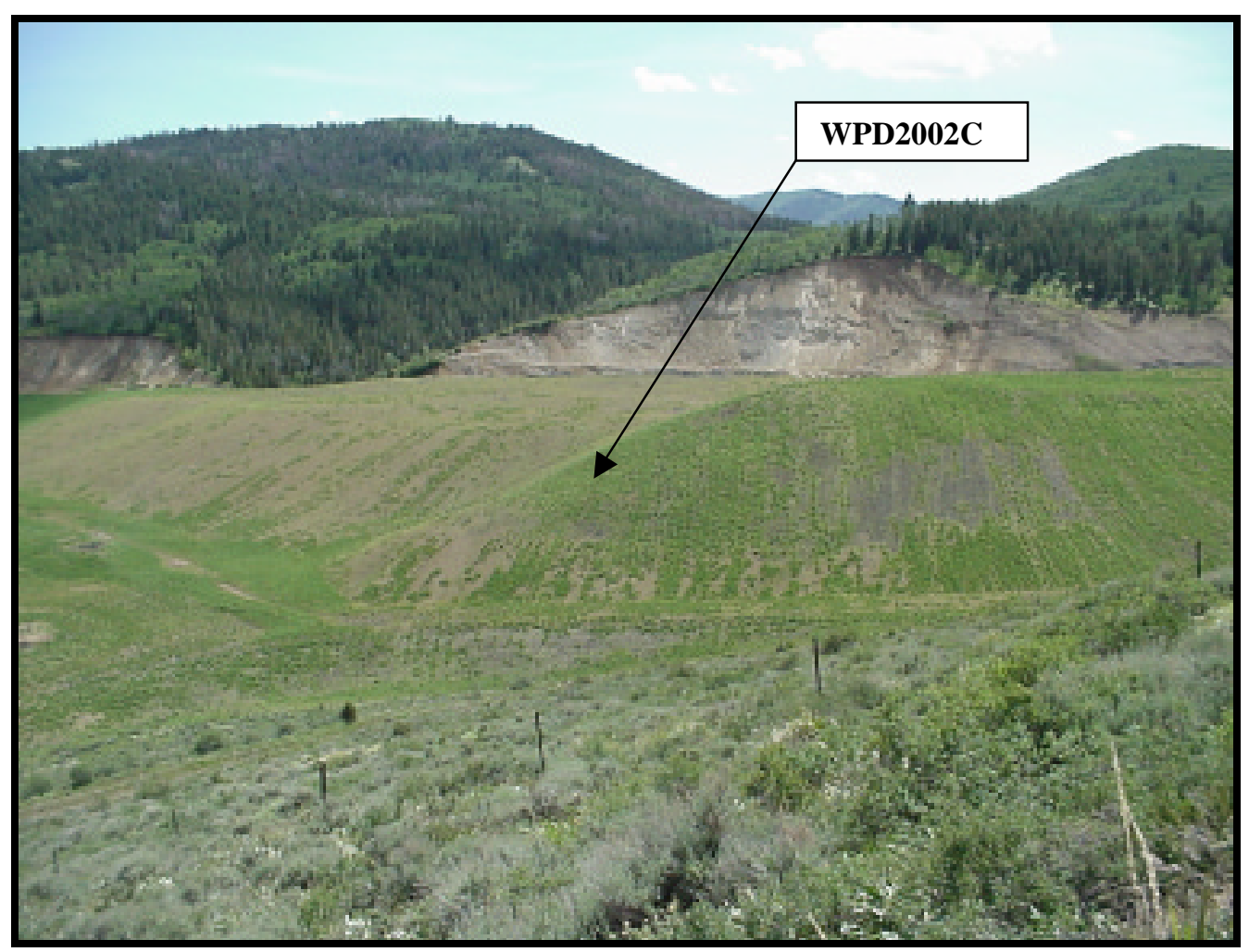

Figure 13. View west of reclaimed waste rock dump at the middle part of Mountain Fuel mine, Caribou County, Idaho, showing sample site WPD2002C.

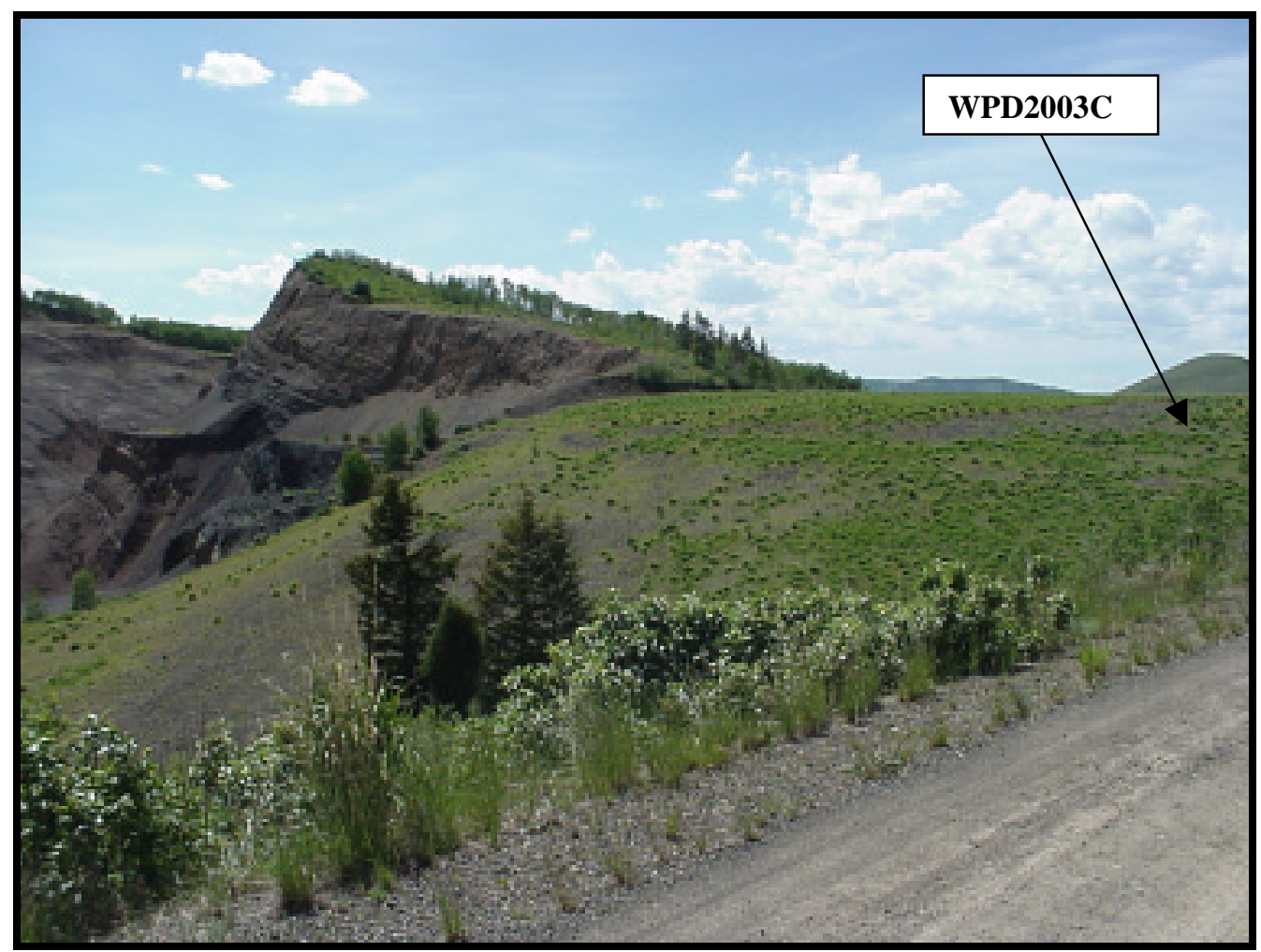

Figure 14. View southwest of partially-reclaimed waste rock dump on the west side of the Mountain Fuel mine, Caribou County, Idaho, showing sample site WPD2003C. 


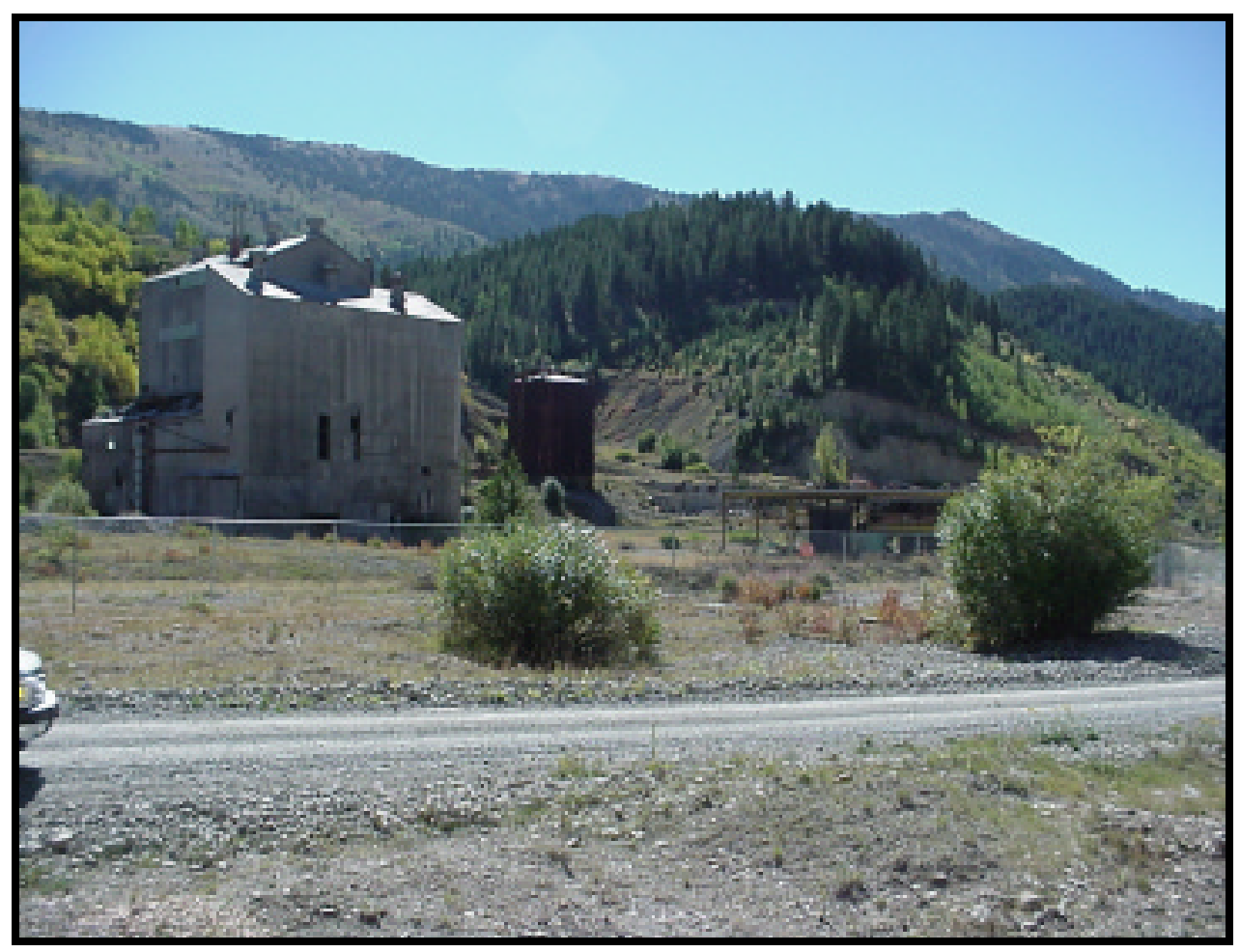

Figure 15. View south of Georgetown mine, Bear Lake County, Idaho, processing plant near sample site WPQ2028C.

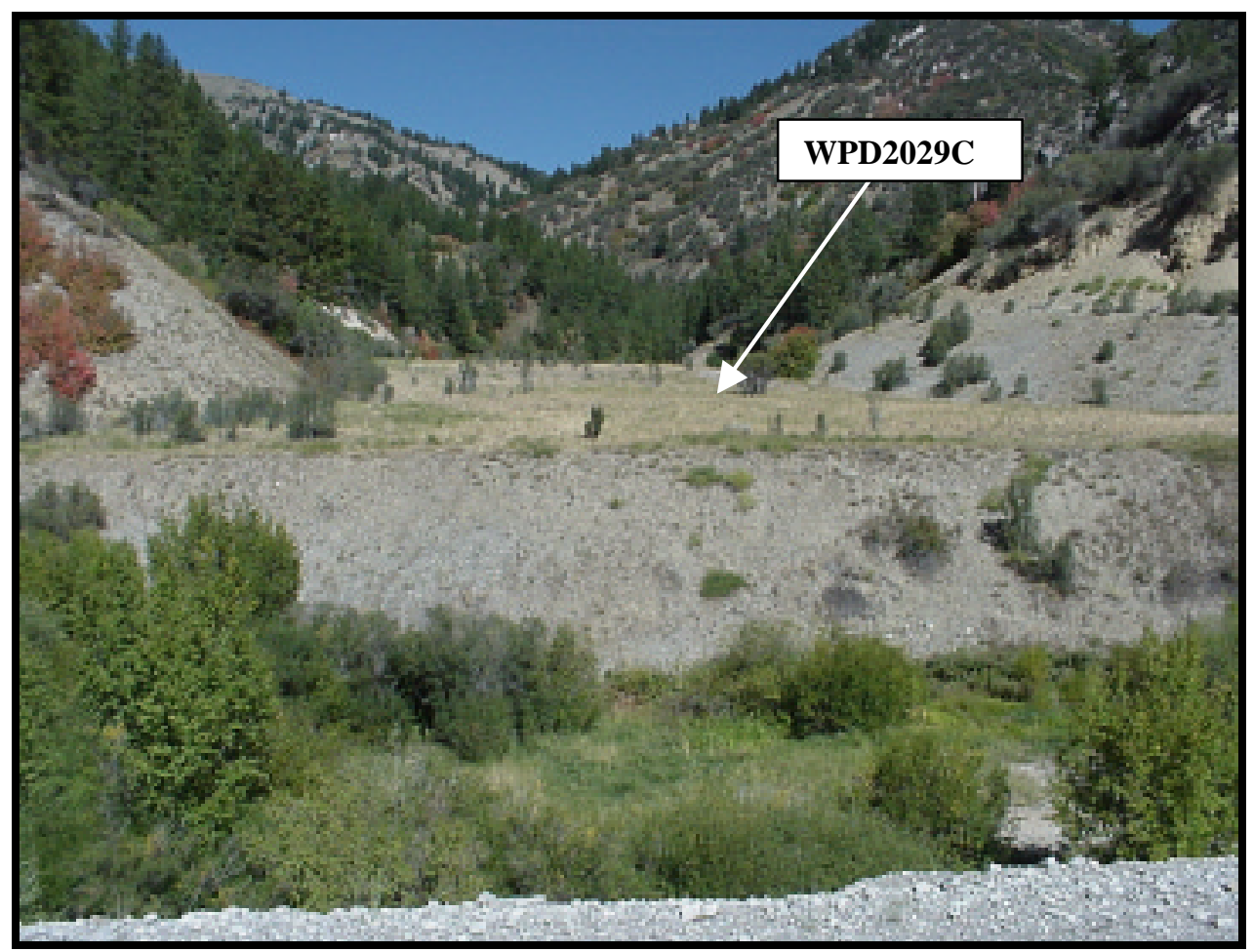

Figure 16. View north of Church Hollow tailings near Georgetown Canyon mine, Bear Lake County, Idaho, showing sample site WPD2029C. 


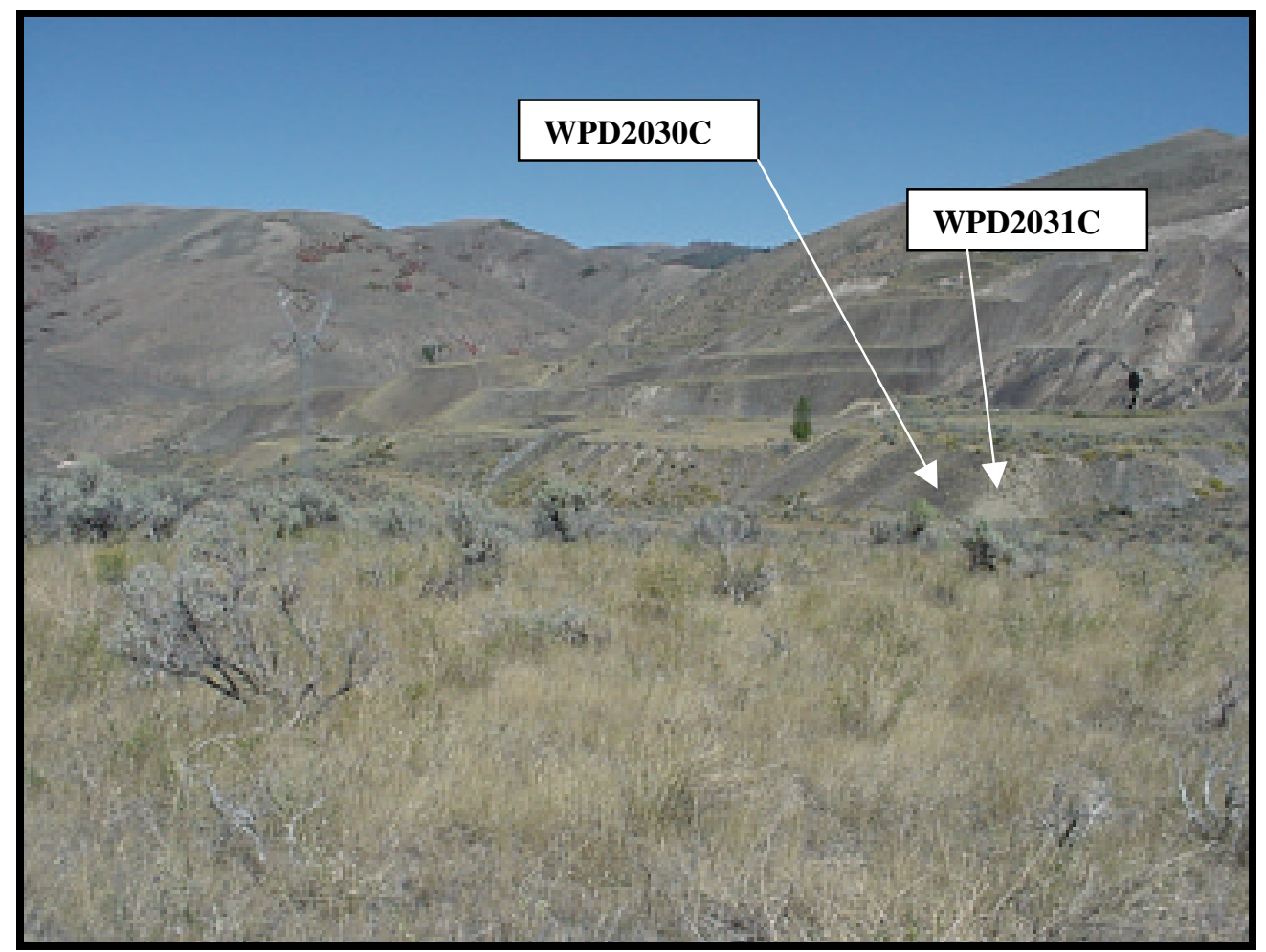

Figure 17. View north of waste rock dumps at the Waterloo mine, Bear Lake County, Idaho, showing sample sites WPD2030C (dark rock) and WPD2031C (light rock).

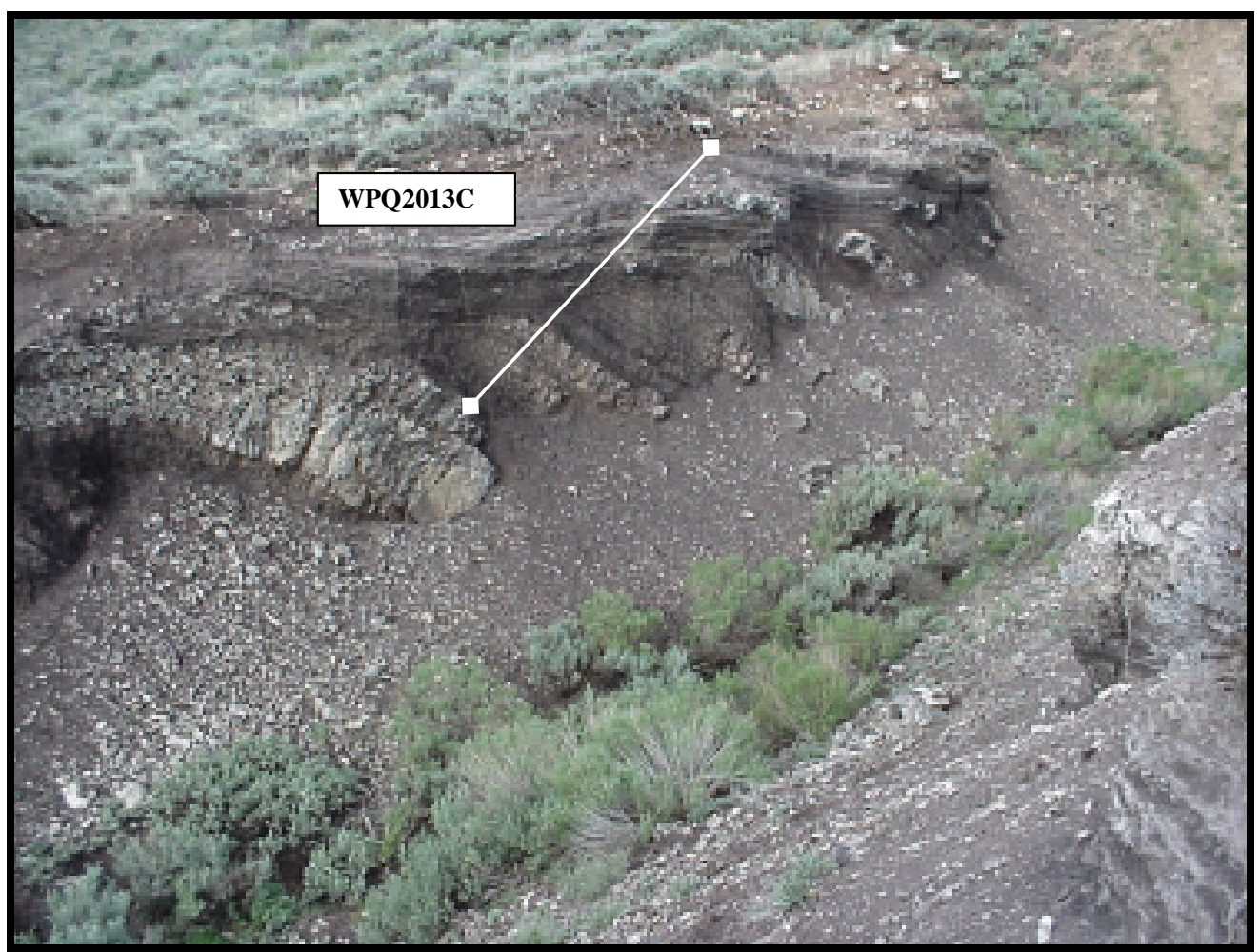

Figure 18. View southwest of sample site at Hot Springs mine, Bear Lake County, Idaho; showing sample WPQ2013C cut along line. 


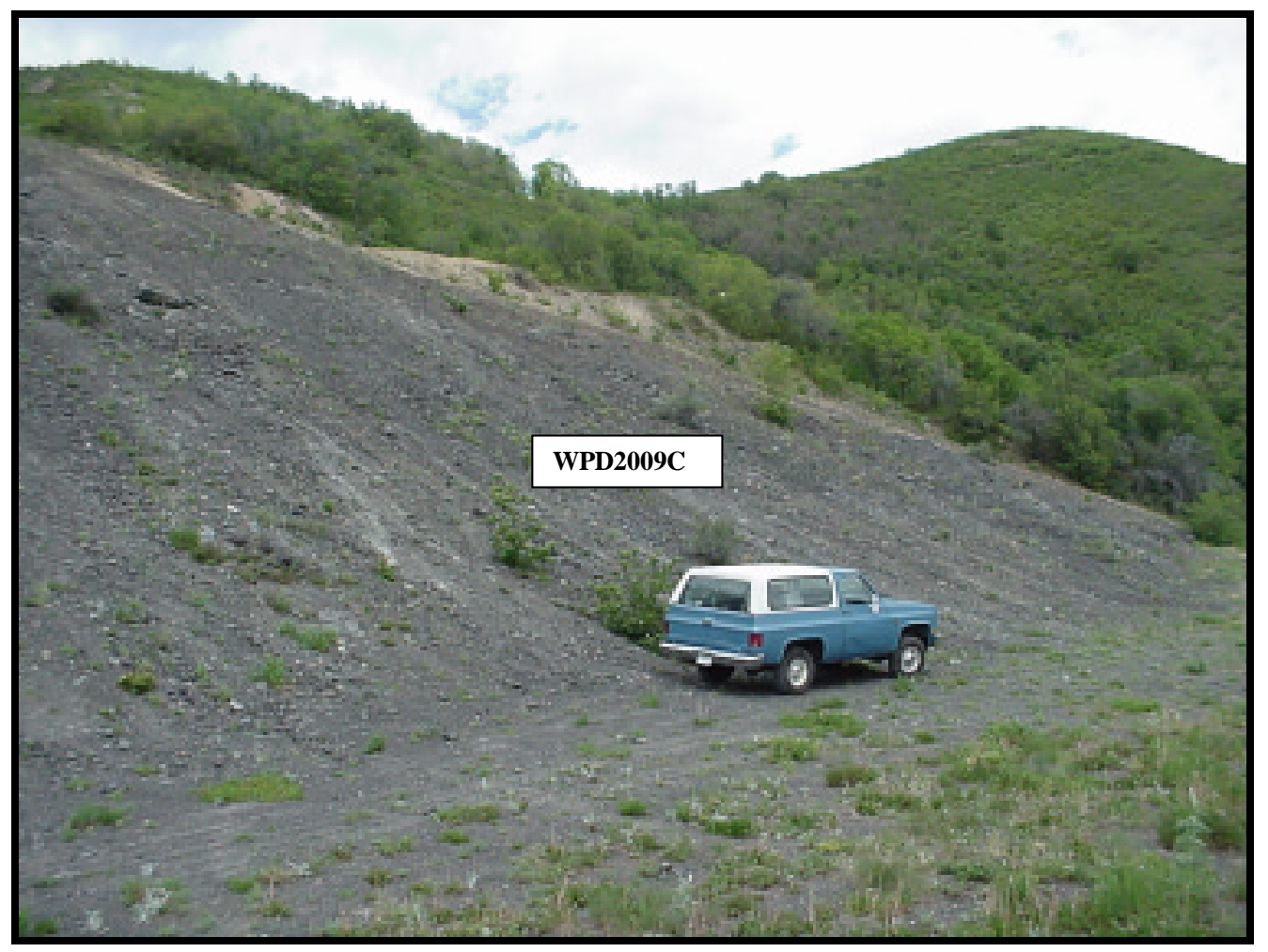

Figure 19. View northwest of waste rock dump at Little Diamond Creek mine, Utah County, Utah, showing sample site WPD2009C.

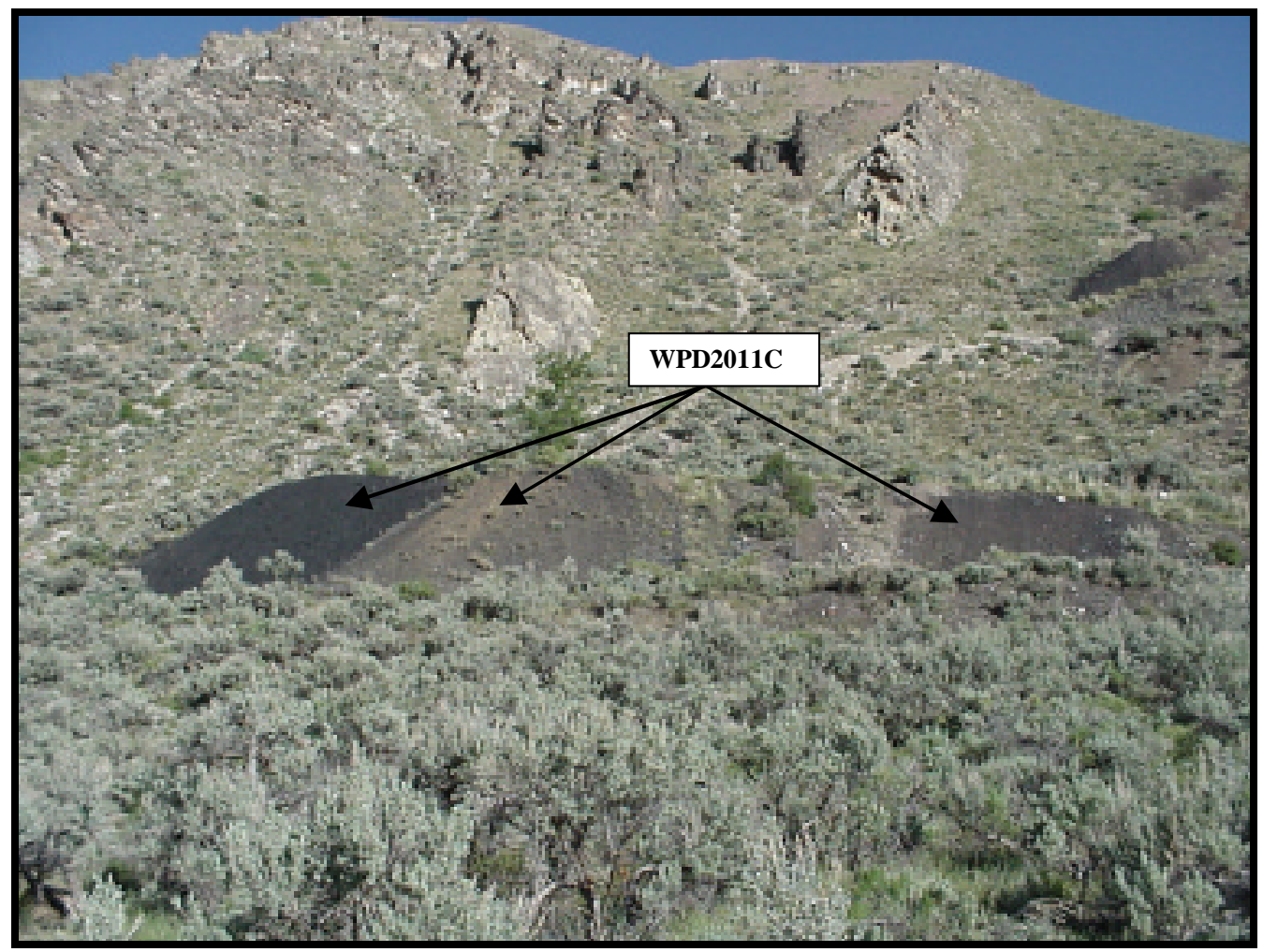

Figure 20. View north of waste rock dumps at Cokeville mine, Lincoln County, Wyoming, showing sample site WPD2011C. 


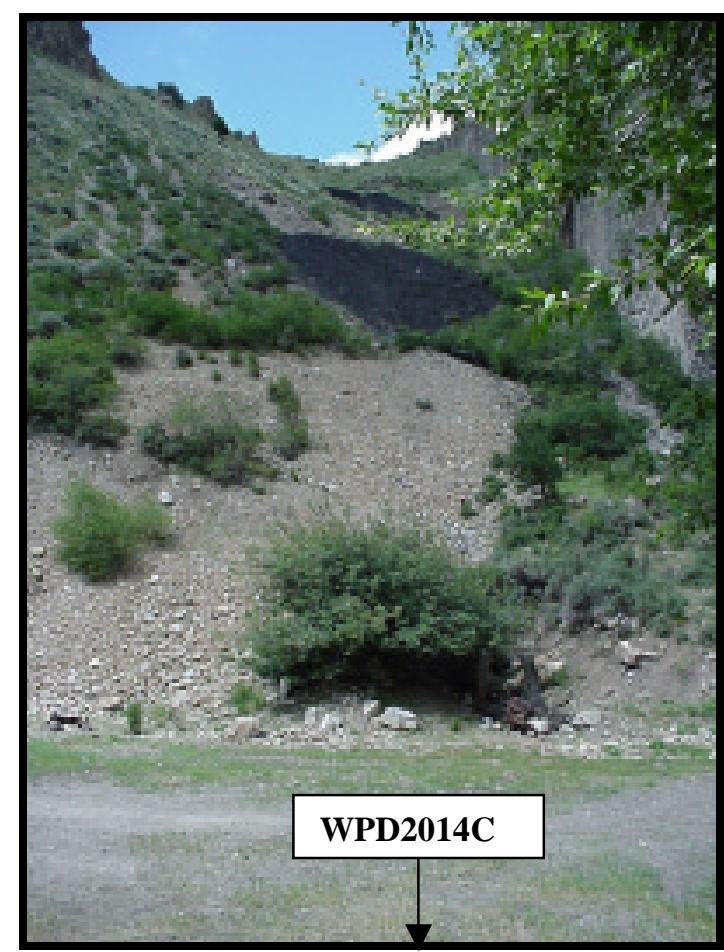

Figure 21. View north of adits and dumps at Raymond Creek mine, Lincoln County, Wyoming. Sample WPD2014C collected from waste rock dump in area from which photograph is taken.

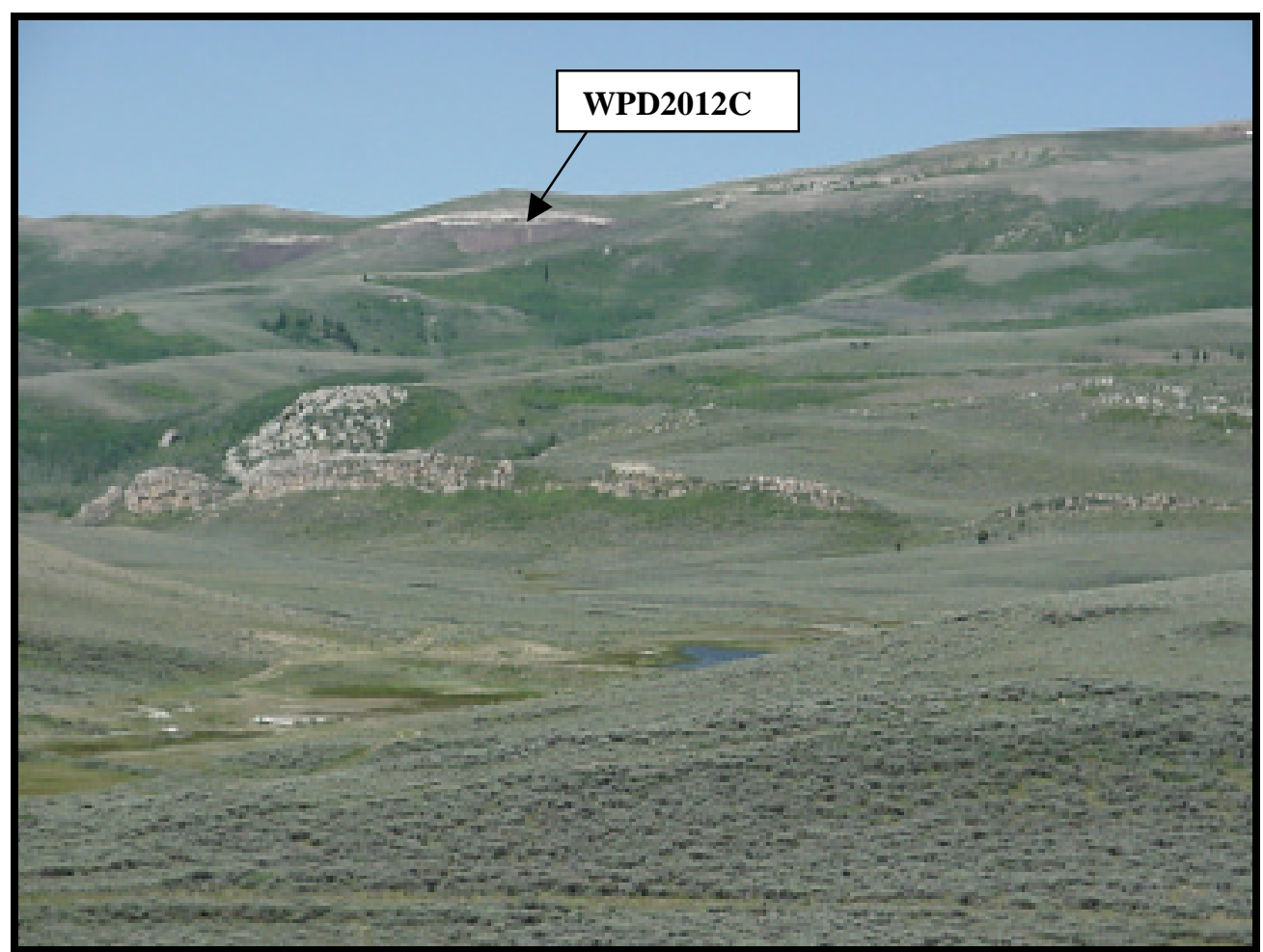

Figure 22. View west toward waste rock dump sampled at South Mountain mine, Lincoln County, Wyoming, showing sample site WPD2012C. 


\section{DISCUSSION}

The analytical results for waste rock dump and other samples exhibit a wide range of element concentrations. Although the data set of 31 samples (tables A-1, A-2, A-3, and A-4) is too small for detailed statistical analysis, a summary of general observations of the chemical analyses is warranted. Several elements occur in concentrations at or below the detection limit of the analytical method. In all samples analyzed, $\mathrm{Au}, \mathrm{Sn}$, and $\mathrm{Ta}$ are below detection, $\mathrm{Bi}$ and $\mathrm{U}$ were detected only in one sample each, and Be is at or near detection limit (2 ppm) in all but two samples. Be was detected in the tailings (WPD2029C) and slag (WPQ2028C) samples, both of which were collected from the Georgetown Canyon mine area.

Table 2 lists reported maximum and minimum concentrations and calculated average concentrations for a suite of selected analytes for all 31 samples. Because this reconnaissance was primarily focused on waste rock dumps, table 2 lists similar data for the subset of 25 samples collected only from dumps. For comparison, the average abundance for each element in shale (Carmichael, 1989) is also included in table 2. Maximum and minimum ranges and average concentration for fourteen of the analytes from the two data sets listed in table 2 are illustrated graphically in figures $23 \mathrm{a}$ and $23 \mathrm{~b}$. The graph in figure 24 plots the average concentration of the fourteen selected analytes in the 25 waste rock dump samples normalized to that of the average abundance of each element in shale. In the 25 waste rock dump samples, only $\mathrm{Co}$ is significantly lower while $\mathrm{Ce}$ and $\mathrm{Pb}$ concentrations are essentially the same as that of average shale. Several elements - As, $\mathrm{Sb}, \mathrm{Tl}, \mathrm{Cr}, \mathrm{Cu}, \mathrm{Ni}$, and $\mathrm{V}$ - are moderately elevated, ranging from 1.5 to 5.6 times those in shale. However, the average concentration of four elements in the waste rock dump samples are significantly elevated compared to their average abundance in shale - Se (x 77), Cd (x 172), Mo (x 19), and Zn (x 12).

The effect of heterogeneous lithology on the chemistry of a waste rock dump is illustrated by the analyses of two samples (WPD2030-31C) from the Waterloo mine near Montpelier, ID (figures 5 and 17). Sample WPD2030C was collected from an exposure of dark gray to black phosphatic shale whereas sample WPD2031C was collected from an exposure of iron-oxide-stained sandy shale and limestone about 15-ft away on the face of the same dump. The sandy shale and limestone sample exhibits low concentrations of $\mathrm{As}, \mathrm{Cd}, \mathrm{Cr}, \mathrm{Cu}, \mathrm{Mo}, \mathrm{Ni}, \mathrm{Se}, \mathrm{Sb}$, and $\mathrm{V}$, and the highest concentration of $\mathrm{Ba}$ - distinctly different than the black shale, which contains much higher concentrations of $\mathrm{As}, \mathrm{Cd}, \mathrm{Cr}, \mathrm{Cu}, \mathrm{Mo}, \mathrm{Ni}, \mathrm{Se}, \mathrm{Sb}$, and $\mathrm{V}$ and lower $\mathrm{Ba}$.

The full data set of 31 samples (figure 23a) shows a wider concentration range of certain elements compared to the 25 collected only from waste rock dumps (figure $23 \mathrm{~b}$ ). The sample of slag (WPQ2028C) exhibits a chemical composition radically different than that of unprocessed rock. The slag sample contains the highest concentration for 17 of the elements determined - Ag, $\mathrm{Co}, \mathrm{Cr}, \mathrm{Cu}, \mathrm{Eu}, \mathrm{Fe}, \mathrm{Ga}, \mathrm{Mn}, \mathrm{Mo}, \mathrm{Nb}, \mathrm{Ni}, \mathrm{P}$, Th, Ti, V, Yb, and $\mathrm{Zr}$ - and the lowest concentration for 17 others - Al, C, Ca, Cd, Hg, K, La, Li, Mg, Na, S, Sc, Se, Sr, Tl, Y, and Zn. However, the extremely high temperature conditions associated with elemental phosphorus production are not typical of the natural processes that operate at the Earth's surface, including waste rock dumps or other impoundments. 
Element concentrations vary considerably because of the differing rock types and wide geographic distribution. That samples from the same waste rock dump exhibit very different chemical compositions calls attention to the caution that must be exercised when attempting to characterize a waste-rock dump.

\section{ACKNOWLEDGEMENTS}

The authors appreciate the help and participation of a number of individuals and companies. Staff from several phosphate mining companies - in particular, Rob Squires, Monty Johnson, and Alan Haslam, Agrium U.S. Inc., Larry Raymond, J.R. Simplot Company, Dan Bersanti, Rhodia, and David Farnsworth and Mike Vice, Monsanto - were very helpful, providing access, maps and historical information for several sites. Land management agency staff also provided logistical support for and input into this research effort. The Shoshone-Bannock Tribal Land Use Council granted permission for field reconnaissance and sampling at the Gay mine, and Sam Hernandez, Bureau of Indian Affairs, Fort Hall, ID, provided historical information, maps, and a tour. 
Table 2. Average, maximum, and minimum concentrations for selected individual and ICP-40 analytes for the 25 samples from waste-rock dumps and for all 31 samples, and average abundance of elements in shale (ppm, parts per million; \%, percent; NR, not reported).

\begin{tabular}{|c|c|c|c|c|c|c|c|c|}
\hline & \multirow{2}{*}{$\begin{array}{c}\text { ANALYTE, } \\
\text { Unit of } \\
\text { Measure }\end{array}$} & \multirow{2}{*}{$\begin{array}{l}\text { AVERAGE } \\
\text { ABUNDANCE }^{\text {IN SHALE }}\end{array}$} & \multicolumn{3}{|c|}{ WASTE DUMP SAMPLES } & \multicolumn{3}{|c|}{ ALL SAMPLES } \\
\hline & & & AVERAGE & MAXIMUM & MINIMUM & AVERAGE & MAXIMUM & MINIMUM \\
\hline \multirow{9}{*}{ 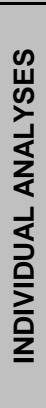 } & As, ppm & 6.6 & 28.0 & 92.8 & 5.6 & 27.1 & 92.8 & 5.6 \\
\hline & $\mathrm{Hg}, \mathrm{ppm}$ & 0.4 & 0.4 & 0.78 & 0.02 & 0.4 & 0.92 & 0.01 \\
\hline & Se, ppm & 0.6 & 46 & 285 & 1.3 & 42 & 285 & 1.3 \\
\hline & Sb, ppm & 1.5 & 6.0 & 24.3 & 0.8 & 6.2 & 24.3 & 0.8 \\
\hline & TI, ppm & 1 & 3.0 & 13.7 & 0.3 & 3.1 & 13.7 & 0.05 \\
\hline & C, \% & 0.1 & 5.2 & 10.2 & 1.77 & 4.8 & 10.2 & 0.47 \\
\hline & $\mathrm{CO} 2, \%$ & $N R$ & 6.5 & 30.2 & 0.36 & 5.7 & 30.2 & 0.36 \\
\hline & CRBNT_C, \% & NR & 1.8 & 8.24 & 0.1 & 1.6 & 8.24 & 0.1 \\
\hline & S, \% & 0.022 & 0.74 & 2.17 & 0.025 & 0.74 & 2.17 & 0.025 \\
\hline \multirow{33}{*}{ 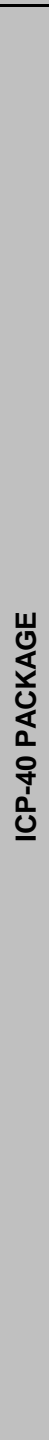 } & Al, \% & 8 & 3.33 & 5.23 & 0.405 & 3.04 & 5.23 & 0.405 \\
\hline & $\mathrm{Ca}, \%$ & 2.5 & 13.4 & 31.7 & 4.16 & 14.7 & 31.7 & 1.27 \\
\hline & $\mathrm{Fe}, \%$ & 4.7 & 1.5 & 2.6 & 0.36 & 2.4 & 31.6 & 0.36 \\
\hline & $\mathrm{K}, \%$ & 2.3 & 1.4 & 2.04 & 0.25 & 1.3 & 2.04 & 0.2 \\
\hline & Mg, \% & 1.34 & 1.4 & 8.365 & 0.16 & 1.1 & 8.365 & 0.125 \\
\hline & $\mathrm{Na}, \%$ & 0.66 & 0.5 & 0.99 & 0.245 & 0.5 & 0.99 & 0.067 \\
\hline & $\mathbf{P}, \%$ & 0.077 & 4.7 & 12.0 & 0.395 & 6.1 & 18.5 & 0.395 \\
\hline & $\mathrm{Ti}, \%$ & 0.45 & 0.1 & 0.27 & 0.017 & 0.1 & 0.337 & 0.017 \\
\hline & $\mathrm{Ag}, \mathrm{ppm}$ & 0.1 & 6 & 12 & 1 & 7 & 27 & 1 \\
\hline & $\mathrm{Ba}, \mathrm{ppm}$ & 580 & 221 & 433 & 64 & 207 & 433 & 64 \\
\hline & Cd, ppm & 0.3 & 52 & 225 & 3 & 59 & 225 & 1 \\
\hline & Ce, ppm & 50 & 48 & 70 & 14 & 46 & 70 & 14 \\
\hline & Co, ppm & 20 & 4 & 8 & 1 & 7 & 111 & 1 \\
\hline & $\mathrm{Cr}, \mathrm{ppm}$ & 100 & 564 & 1880 & 8 & 1617 & 30800 & 8 \\
\hline & $\mathrm{Cu}, \mathrm{ppm}$ & 57 & 83 & 230 & 23 & 227 & 4330 & 23 \\
\hline & Eu, ppm & 1 & 2 & 8 & 1 & 3 & 9 & 1 \\
\hline & Ga, ppm & 19 & 15 & 45 & 4 & 19 & 164 & 4 \\
\hline & Ho, ppm & 1 & 5 & 14 & 2 & 4 & 14 & 2 \\
\hline & La, ppm & 40 & 115 & 420 & 21 & 125 & 420 & 10 \\
\hline & Li, ppm & 60 & 22 & 47 & 7 & 21 & 47 & 3 \\
\hline & Mn, ppm & 850 & 195 & 1240 & 20 & 262 & 2200 & 20 \\
\hline & Mo, ppm & 2 & 39 & 225 & 3 & 75 & 1150 & 3 \\
\hline & $\mathrm{Nb}, \mathrm{ppm}$ & 20 & 6 & 14 & 2 & 6 & 35 & 2 \\
\hline & Nd, ppm & 23 & 76 & 249 & 4.5 & 82 & 249 & 4.5 \\
\hline & $\mathrm{Ni}, \mathrm{ppm}$ & 95 & 180 & 486 & 19 & 408 & 7280 & 19 \\
\hline & $\mathrm{Pb}, \mathrm{ppm}$ & 20 & 14 & 27 & 6 & 15 & 35 & 6 \\
\hline & Sc, ppm & 10 & 7 & 11 & 1 & 6 & 11 & 1 \\
\hline & Sr, ppm & 450 & 518 & 1150 & 175 & 558 & 1150 & 53 \\
\hline & Th, ppm & 11 & 7 & 12 & 3 & 7 & 28 & 3 \\
\hline & $\mathrm{V}, \mathrm{ppm}$ & 130 & 628 & 3200 & 74 & 1852 & 35840 & 74 \\
\hline & Y, ppm & 30 & 155 & 511 & 20 & 170 & 511 & 14 \\
\hline & Yb, ppm & 3 & 7 & 18 & 2 & 9 & 39 & 2 \\
\hline & Zn, ppm & 80 & 992 & 3570 & 118 & 1030 & 3570 & 56 \\
\hline
\end{tabular}

(1/ Carmichael, 1989, table 71) 


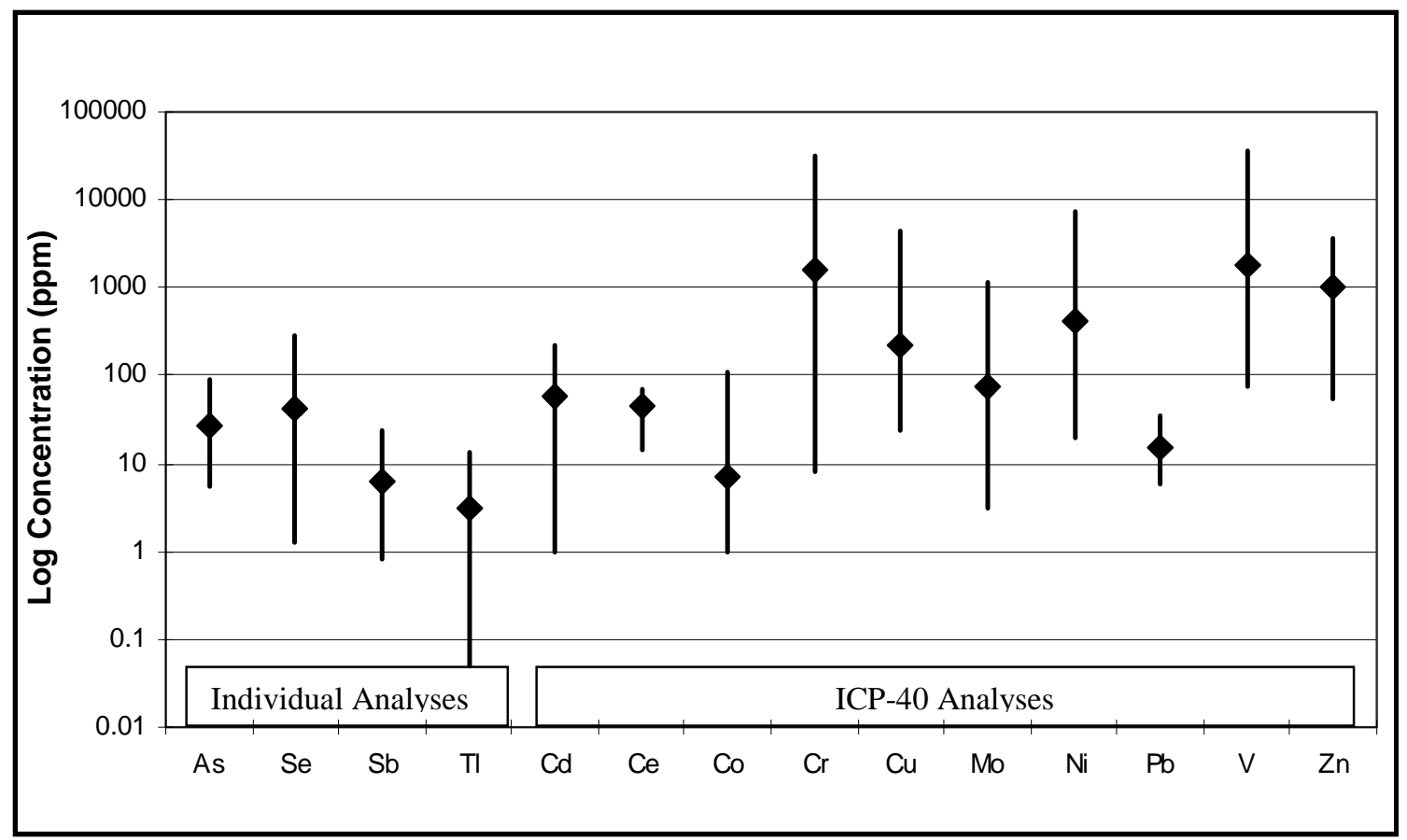

Figure 23a. Range and average concentrations of selected elements for all 31 samples analyzed (ppm $=$ parts per million).

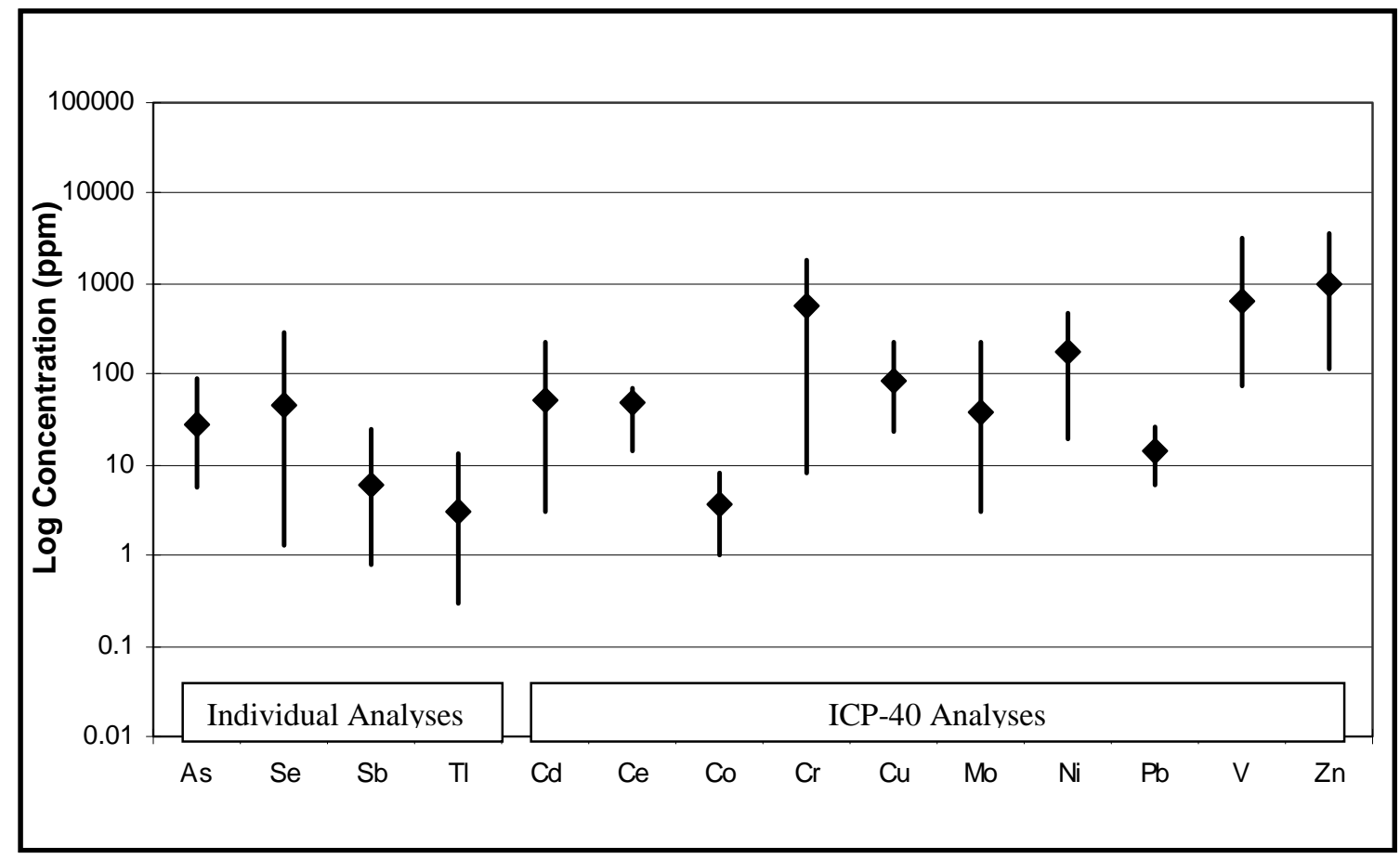

Figure 23b. Range and average concentrations of selected elements for 25 waste rock dump samples analyzed ( $\mathrm{ppm}=$ parts per million). 


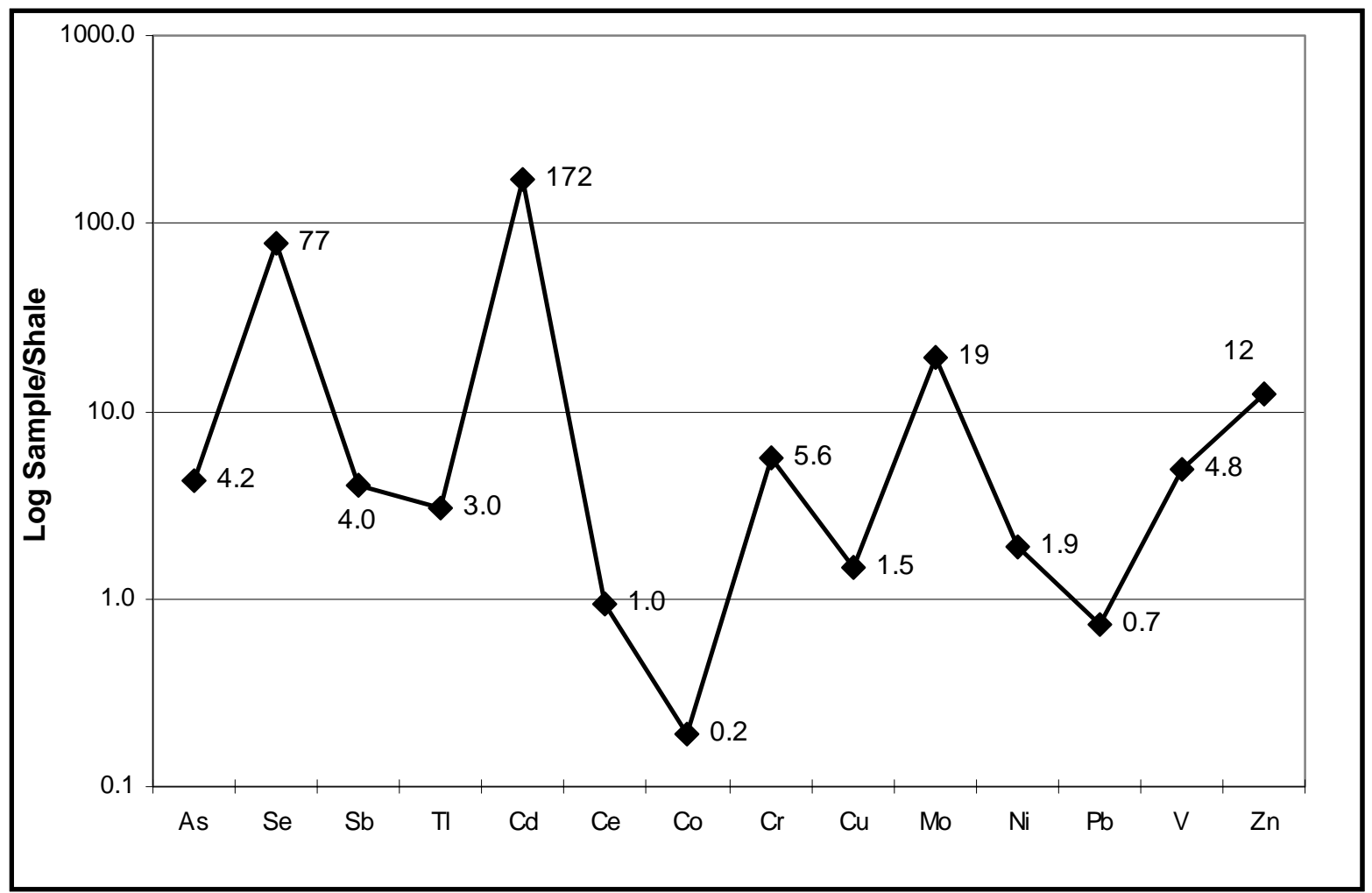

Figure 24. Graph of average concentration of selected elements for 25 waste-rock dump samples normalized to the average abundance of the elements in average world-wide shales (Carmichael, 1989, table 71). 


\section{REFERENCES CITED}

Altschuler, Z.S., 1980, The geochemistry of trace elements in marine phosphorites, Part I. Characteristic abundances and enrichment: Society of Economic Paleontologists and Mineralogists, Special Publication 29, p. 19-30.

Bureau of Mines, 1968, A dictionary of mining, mineral, and related terms: Bureau of Mines, Special Publication, $1269 \mathrm{p}$.

Carmichael, R.S., 1989, Practical handbook of physical properties of rocks and minerals: Boca Raton, Florida, CRC Press, 741 p.

Causey, J.D., and Moyle, P.R., 2001, Digital database of mining-related features at selected historic and active phosphate mines, Bannock, Bear Lake, Bingham, and Caribou Counties, Idaho: U.S. Geological Survey Open-File Report 01-142, 50 p.

Crock, J.G., Lichte, F.E., and Briggs, P.E., 1983, Determination of elements in National Bureau of Standards Geologic Reference Materials SRM 278 obsidian and SRM 688 basalt by inductively coupled argon plasma-atomic emission spectrometry: Geostandards Newsletter, vol. 7, p. 335-340.

Desborough, G.A., 1977, Preliminary report on certain metals of potential economic interest in thin vanadium-rich zones in the Meade Peak member of the Phosphoria Formation in western Wyoming and eastern Idaho: U.S. Geological Survey Open-File Report 77-341, $27 \mathrm{p}$.

Desborough, G., DeWitt, E., Jones, J., Meier, A. and Meeker, G., 1999, Preliminary mineralogical and chemical studies related to the potential mobility of selenium and associated elements in Phosphoria Formation strata, southeastern Idaho: U.S. Geological Survey Open-File Report 99-129, 20 p.

Desborough, G.A., Grauch, R.I., Crock, J.G., Meeker, G.P., Herring, J.R., and Tysdal, R.G., 2000, Low temperature volatilization of selenium from rock samples of the Phosphoria Formation in southeastern Idaho: U.S. Geological Survey Open-File Report 00-009, 9 p.

Grauch, R.I., Meeker, G.P., Desborough, G.A., Driscoll, R.L., Herring, J.R., Tysdal, R.G., and Johnson, E.A., 2000a, Selenium and nickel mobility in the Phosphoria Formation [abstract]: Geological Society of America meeting, November, 2000.

Grauch, R.I., Meeker, G.P., Desborough, G.A., Tysdal, R.G., Herring, J.R., and Moyle, P.R., 1999, Selenium residence in the Phosphoria Formation [abstract]: Geological Society of America Abstracts with Programs, v. 31, no. 7, p. A35.

Grauch, R.I., Meeker, G.P., Herring, J.R., Tysdal, R.G., Desborough, G.A., Johnson, E.A., and Moyle, P.R., 2000b, Selenium, phosphate mining and the environment [abstract]: Northwest Mining Association $106^{\text {th }}$ Annual Meeting, USGS Open Industry Briefing, December 5, 2000.

Gulbrandsen, R.A., 1966, Chemical composition of phosphorites of the Phosphoria Formation: Geochimica et Cosmochimica Acta, v. 30, no. 8, p. 769-778.

Gulbrandsen, R.A., and Krier, D.J., 1980, Large and rich phosphorus resources in the Phosphoria Formation in the Soda Springs area southeastern Idaho: U.S. Geological Survey Bulletin 1496, $25 \mathrm{p}$.

Herring, J.R., 1995, Permian phosphorites; a paradox of phosphogenesis in, Scholle, P.A., Peryt, T.M., and Ulmer-Scholle, D.S. (eds.), The Permian of northern Pangea; v. 2, Sedimentary basins and economic resources: Berlin, Springer-Verlag, p. 292-312. 
Herring, J.R., Desborough, G.A., Tysdal, R.G., Grauch, R.I., and Gunter, M.E., 1999a, Selenium in weathered and unweathered parts of the Meade Peak Phosphatic member of the Phosphoria Formation, southeastern Idaho [abstract]: Geological Society of America Abstracts with Programs, Rocky Mountain Section, April 1999.

Herring, J.R., Desborough, G.A., Wilson, S.A., Tysdal, R.G., Grauch, R.I., and Gunter, M.E., 1999b, Chemical composition of weathered and unweathered strata of the Meade Peak Phosphatic Shale Member of the Permian Phosphoria Formation-A. Measured sections A and B, central part of Rasmussen Ridge, Caribou County, Idaho: U.S. Geological Survey Open-File Report 99-147-A, 24 p.

Herring, J.R., and Fantel, R.J., 1993, Phosphate rock demand into the next century: impact on world food supply: Nonrenewable Resources, v. 2, no. 3, p. 226-246.

Herring, J.R., Grauch, R.I., Desborough, G.A., Tysdal, R.G., 1999c, Environmentally sensitive trace elements in weathered and unweathered parts of the Meade Peak Phosphatic Shale Member of the Phosphoria Formation, southeastern Idaho, U.S. [abstract]: SGA/IAGOD meeting in London, August, 1999.

Herring, J.R., Grauch, R.I., Desborough, G.A., Wilson, S.A., and Tysdal, R.G., 2000a, Chemical composition of weathered and less weathered strata of the Meade Peak Phosphatic Shale Member of the Permian Phosphoria Formation-C. Measured sections E and F, Rasmussen Ridge, Caribou County, Idaho: U.S. Geological Survey Open-File Report 99$147-\mathrm{C}, 35 \mathrm{p}$.

Herring, J.R., Grauch, R.I., Tysdal, R.G., Wilson, S.A., and Desborough, G.A., 2000b, Chemical composition of weathered and less weathered strata of the Meade Peak Phosphatic Shale Member of the Permian Phosphoria Formation--D. Measured sections G and H, Sage Creek Canyon area of the Webster Range, Caribou County, Idaho, U.S. Geological Survey Open-File Report 99-147-D, 38 p.

Herring, J.R., and Stowasser, W.F., 1991, Phosphate-our nation's most important agricultural mineral commodity and its uncertain future: Geological Society of America, Abstracts with Programs, v. 23, no. 5, p. 299-300.

Herring, J.R., Wilson, S.A., Stillings, L.A., Knudsen, A.C., Gunter, M.E., Tysdal, R.G., Grauch, R.I., Desborough, G.A., and Zielinski, R.A., 2000c, Chemical composition of weathered and less weathered strata of the Meade Peak Phosphatic Shale Member of the Permian Phosphoria Formation-B. Measured sections C and D, Dry Valley, Caribou County, Idaho: U.S. Geological Survey Open-File Report 99-147-B, 33 p.

Lee, W.H., 2001, A history of phosphate mining in southeastern Idaho: U.S. Geological Survey Open-File Report 00-425 (CD-ROM), 253 p.

Mansfield, G.R., 1918, Origin of the western phosphates of the United States: American Journal of Science, 4th Series, v. 46, no. 274, article 27, pp. 591-598.

---, 1920, Geography, geology and mineral resources of the Fort Hall Indian Reservation, Idaho: U.S. Geological Survey Bulletin 713, 152 p.

---, 1927, Geography, geology, and mineral resources of part of southeastern Idaho with a description of Carboniferous and Triassic fossils, by G. H. Girty: U.S. Geological Survey Professional Paper 152, $453 \mathrm{p}$.

---, 1933, The western phosphate field, in Ore deposits of the western states (Lindgren Volume): New York, American Institute of Mining, Metallurgical and Petroleum Engineers, p. 491-496. 
McKelvey, V.E., Armstrong, F.C., Gulbrandsen, R.A., and Campbell, R.M., 1953a, Stratigraphic sections of the Phosphoria Formation in Idaho, 1947-48, pt. 2: U.S. Geological Survey Circular 301, $52 \mathrm{p}$.

McKelvey, V.E., Davidson, D.F., O'Malley, F.W., and Smith, L.E., 1953b, Stratigraphic sections of the Phosphoria Formation in Idaho, 1947-48, pt. 1: U.S. Geological Survey Circular 208, 49 p.

---, 1959, The Phosphoria, Park City, and Shedhorn Formations in the western phosphate field: U.S. Geological Survey Professional Paper 313-A, 47 p.

---, 1967, The Phosphoria, Park City, and Shedhorn Formations in western phosphate field, in Anatomy of the western phosphate field, a guide to the geologic occurrence, exploration methods, mining engineering, and recovery technology: Intermountain Association of Geologists, 15th Annual Field Conference, p. 15-33.

Piper, D.Z., 1974, Rare earth elements in the sedimentary cycle: a summary: Geochemical Geology, v. 14, no. 4, p. 285-304.

Piper, D.Z., 1999a, Trace elements and major-element oxides in the Phosphoria Formation at Enoch Valley, Idaho-Permian Sources and current reactivities: U.S. Geological Survey Open-File Report 99-163, 66 p.

Piper, D. Z., 1999b, Ancient sources and current hosts and reactivities of trace elements in the Phosphoria Formation [abstract]: Geological Society of America Abstracts with Programs, Rocky Mountain Section, April 1999.

Service, A.L., 1966, An evaluation of the western phosphate industry and its resources (in five parts), 3. Idaho: U.S. Bureau of Mines Report of Investigations 6801, 201 p.

---, 1967, Evaluation of the phosphate reserves in southeastern Idaho, in Hale, L.A., ed., Anatomy of the western phosphate field, a guide to the geologic occurrence, exploration methods, mining engineering, and recovery technology: Intermountain Association of Geologists, 15th Annual Field Conference, p. 73-96.

Service, A.L., and Popoff, C.C., 1964, An evaluation of the western phosphate industry and its resources (in five parts), pt. 1. Introductory review: U.S. Bureau of Mines Report of Investigations 6485, $86 \mathrm{p}$.

Sheldon, R.P., 1963, Physical stratigraphy and mineral resources of Permian rocks in western Wyoming: U.S. Geological Survey Professional Paper 313-B, p. B49-B273.

---, 1989, Phosphorite deposits of the Phosphoria Formation, western United States, in Notholt, A.J.G., Sheldon, R.P., and Davidson, D.F., eds., Phosphate deposits of the world: Cambridge, U.K., Cambridge University Press, v. 2, p. 55-61.

Van Wazer, J.R., 1961, Phosphorus and its compounds - volume II: technology, biological functions, and applications: New York, Interscience Publishers, Inc., p. 955-2046. 


\section{APPENDIX A. Data Tables}

Table A-1. Sample descriptions and locations.

Table A-2. Individual and ICP-10 analyses.

Table A-3. ICP-16 analyses.

Table A-4. ICP-40 analyses. 
Table A-1. Sample descriptions and locations.

\begin{tabular}{|c|c|c|c|c|c|c|c|c|c|c|c|c|c|c|c|}
\hline \multicolumn{7}{|c|}{ SAMPLE INFORMATION } & \multicolumn{9}{|c|}{ LOCATION } \\
\hline $\begin{array}{l}\text { FIELD } \\
\text { NUMBER }\end{array}$ & $\begin{array}{l}\text { LAB } \\
\text { NUMBER }\end{array}$ & SITE NAME & FEATURE & TYPE & LITHOLOGY & DATE & $\begin{array}{l}\text { QUADRANGLE } \\
\text { MAP }\end{array}$ & COUNTY & STATE & LON_dec & LAT_dec & TWSP & RANGE & SECTION & PARCEL \\
\hline WPD2001C & C-136960 & Champ Mine & waste dump & composite & black shale \& limestone & $06 / 19 / 99$ & Dry Valley & Caribou & ID & -111.2712 & 42.6752 & $9 S$ & $44 \mathrm{E}$ & 2 & NNE \\
\hline WPD2002C & C-136961 & Mountain Fuel Mine & waste dump & composite & black shale \& limestone & $06 / 19 / 99$ & Dry Valley & Caribou & ID & -111.2758 & 42.6399 & $9 \mathrm{~S}$ & $44 \mathrm{E}$ & 14 & NSE \\
\hline WPD2003C & C-136962 & Mountain Fuel Mine & waste dump & composite & black shale \& limestone & 06/19/99 & Dry Valley & Caribou & ID & -111.2859 & 42.6465 & $9 \mathrm{~S}$ & $44 \mathrm{E}$ & 14 & NWNW \\
\hline WPD2004C & C-136963 & Diamond Gulch Mine & waste dump & composite & black shale \& limestone & $06 / 20 / 99$ & Fossil Canyon & Caribou & ID & -111.4401 & 42.6031 & $9 S$ & $43 \mathrm{E}$ & 33 & NENW \\
\hline WPD2005C & C-136964 & Ballard Mine & waste dump & composite & shale & $06 / 21 / 99$ & Lower Valley & Caribou & ID & -111.4730 & 42.8359 & $7 S$ & $43 \mathrm{E}$ & 7 & NWNE \\
\hline WPD2006C & C-136965 & Maybe Canyon adit & waste dump & composite & black shale & $06 / 24 / 99$ & Dry Valley & Caribou & ID & -111.2982 & 42.7472 & $8 \mathrm{~S}$ & $44 \mathrm{E}$ & 10 & WNE \\
\hline WPD2007C & C-136966 & Home Canyon Mine & waste dump & composite & black shale & $06 / 25 / 99$ & Montpelier Canyon & Bear Lake & ID & -111.2353 & 42.3309 & $12 \mathrm{~S}$ & $45 \mathrm{E}$ & 31 & SWSE \\
\hline WPD2008C & C-136967 & Home Canyon Mine & stockpile & composite & phosphorite & $06 / 25 / 99$ & Montpelier Canyon & Bear Lake & ID & -111.2350 & 42.3311 & $12 \mathrm{~S}$ & $45 \mathrm{E}$ & 31 & swsw \\
\hline WPD2009C & C-175612 & Little Diamond & waste dump & composite & black shale \& phosphorite & $06 / 08 / 00$ & Billies Mountain & Utah & UT & -111.4654 & 40.1008 & $8 S$ & $4 \mathrm{E}$ & 22 & SE \\
\hline WPD2010C & C-175613 & Benjamin Mine & waste dump & composite & black shale \& phosphorite & 06/09/00 & Rex Peak & Rich & UT & -111.0791 & 41.6926 & $11 \mathrm{~N}$ & $8 \mathrm{E}$ & 18 & NWSE \\
\hline WPD2011C & C-175614 & Cokeville Mine & stockpile & composite & shale \& oolitic phosphorite & $06 / 11 / 00$ & Cokeville & Lincoln & WY & -110.9374 & 42.0992 & $24 \mathrm{~N}$ & $119 \mathrm{~W}$ & 4 & NENW \\
\hline WPD2012C & C-175615 & South Mountain Mine & waste dump & composite & black oolitic phosphorite & $06 / 11 / 00$ & Sublet & Lincoln & WY & -110.5823 & 41.9813 & $23 \mathrm{~N}$ & $116 \mathrm{~W}$ & 9 & SE \\
\hline WPQ2013C & C-175616 & Hot Springs Mine & outcrop & chip (4.5') & $\begin{array}{l}\text { flat-lying organic-rich shale } \\
\text { \& phosphorite }\end{array}$ & 06/13/00 & Bear Lake North & Bear Lake & ID & -111.2528 & 42.1322 & $15 \mathrm{~S}$ & $44 \mathrm{E}$ & 12 & NWSE \\
\hline WPD2014C & C-175617 & Raymond Creek & waste dump & composite & black shale & $06 / 13 / 00$ & Geneva & Lincoln & WY & -111.0217 & 42.2772 & $26 \mathrm{~N}$ & $119 \mathrm{~W}$ & 6 & NWNE \\
\hline WPD2015C & C-175618 & $\begin{array}{l}\text { Dry Creek - USBM } \\
\text { adit }\end{array}$ & waste dump & composite & black shale & $06 / 14 / 00$ & Red Top Mountain & Lincoln & WY & -110.8729 & 42.6886 & $31 \mathrm{~N}$ & $118 \mathrm{~W}$ & 10 & NW \\
\hline WPD2016C & C-175619 & Rattle Snake Mine & waste dump & composite & brown-black shale & $06 / 21 / 00$ & Fossil Canyon & Bear Lake & ID & -111.3948 & 42.5497 & $10 \mathrm{~S}$ & $43 \mathrm{E}$ & 14 & SWSE \\
\hline WPD2017C & C-175620 & $\begin{array}{l}\text { Wooley Valley Mine, } \\
\text { Unit } 1\end{array}$ & waste dump & composite & brown-black shale & 06/23/00 & Lower Valley & Caribou & ID & -111.3866 & 42.7951 & 7 & 43 & 24 & SWSW \\
\hline WPD2018C & C-175621 & Henry Mine, central & waste dump & composite & gray-black shale & $06 / 23 / 00$ & Lower Valley & Caribou & ID & -111.4764 & 42.8721 & 6 & 42 & 25 & $\mathrm{NE}$ \\
\hline WPD2019C & C-175622 & $\begin{array}{l}\text { Wooley Valley Mine, } \\
\text { Unit 4, face level } 5\end{array}$ & waste dump & composite & dark brown shale & $06 / 23 / 00$ & Lower Valley & Caribou & ID & -111.3913 & 42.8168 & 7 & 43 & 14 & $\mathrm{NE}$ \\
\hline WPD2020C & C-175623 & $\begin{array}{l}\text { Wooley Valley Mine, } \\
\text { Unit 4, face level } 4\end{array}$ & waste dump & composite & brown-black shale $\&$ chert & $06 / 23 / 00$ & Lower Valley & Caribou & ID & -111.3927 & 42.8183 & 7 & 43 & 14 & NE \\
\hline WPD2021C & C-175624 & $\begin{array}{l}\text { Wooley Valley Mine, } \\
\text { Unit 4, face level } 3\end{array}$ & waste dump & composite & brown-black shale $\&$ chert & $06 / 23 / 00$ & Lower Valley & Caribou & ID & -111.3945 & 42.8201 & 7 & 43 & 14 & $\mathrm{NE}$ \\
\hline WPD2022C & C-175625 & $\begin{array}{l}\text { Wooley Valley Mine, } \\
\text { Unit 4, face level } 2\end{array}$ & waste dump & composite & $\begin{array}{l}\text { brown shale, chert, } \\
\text { limestone, \& siltstone }\end{array}$ & 06/23/00 & Lower Valley & Caribou & ID & -111.3960 & 42.8217 & 7 & 43 & 14 & $\mathrm{NE}$ \\
\hline
\end{tabular}


Table A-1. Sample descriptions and locations. - continued

\begin{tabular}{|c|c|c|c|c|c|c|c|c|c|c|c|c|c|c|c|}
\hline \multicolumn{7}{|c|}{ SAMPLE INFORMATION } & \multicolumn{9}{|c|}{ LOCATION } \\
\hline $\begin{array}{c}\text { FIELD } \\
\text { NUMBER }\end{array}$ & $\begin{array}{l}\text { LAB } \\
\text { NUMBER }\end{array}$ & SITE NAME & FEATURE & TYPE & LITHOLOGY & DATE & $\begin{array}{l}\text { QUADRANGLE } \\
\text { MAP }\end{array}$ & COUNTY & STATE & LON_dec & LAT_dec & TWSP & RANGE & SECTION & PARCEL \\
\hline WPD2023C & C-175626 & $\begin{array}{l}\text { Wooley Valley Mine, } \\
\text { Unit 4, face level } 1\end{array}$ & waste dump & composite & $\begin{array}{l}\text { gray-brown shale, chert, } \\
\text { siltstone, \& limestone }\end{array}$ & | 06/23/00 & Lower Valley & Caribou & ID & -111.3966 & 42.8223 & 7 & 43 & 14 & $\mathrm{NE}$ \\
\hline WPD2024C & C-175627 & $\begin{array}{l}\text { Woodall Mountain } \\
\text { Mine }\end{array}$ & waste dump & composite & gray-black shale & $06 / 26 / 00$ & Soda Springs & Caribou & ID & -111.5094 & 42.7451 & 8 & 42 & 11 & $\mathrm{NE}$ \\
\hline WPD2025C & C-175628 & Conda Mine & waste dump & composite & $\begin{array}{l}\text { tan-brown shale, limestone, } \\
\text { \& pelletal phosphorite }\end{array}$ & $06 / 26 / 00$ & Soda Springs & Caribou & ID & -111.5156 & 42.7214 & 8 & 42 & 14 & SWSWSW \\
\hline WPQ2026C & C-175629 & Gay Mine & mill shale pile & composite & gray-black shale & $06 / 26 / 00$ & Yandell Springs & Bannock & ID & -112.1264 & 43.0222 & 5 & 37 & 4 & NWNE \\
\hline WPD2027C & C-175630 & Gay Mine & waste dump & composite & $\begin{array}{l}\text { brown-gray shale \& } \\
\text { limestone }\end{array}$ & $06 / 26 / 00$ & Yandell Springs & Bingham & ID & -112.1294 & 43.0326 & 4 & 37 & 33 & E NW \\
\hline WPQ2028C & C-175631 & $\begin{array}{l}\text { Georgetown Mine - } \\
\text { plant }\end{array}$ & slag pile & select & gray, metallic & $06 / 26 / 99$ & Harrington Peak & Bear Lake & ID & -111.2617 & 42.5297 & 10 & 44 & 25 & NENW \\
\hline WPD2029C & C-185794 & $\begin{array}{l}\text { Georgetown Canyon - } \\
\text { Church Hollow }\end{array}$ & tailings & composite & $\begin{array}{l}\text { brownish-gray, fine-grained, } \\
\text { phosphatic shale w/ pea- } \\
\text { sized gravel }\end{array}$ & $09 / 12 / 00$ & Harrington Peak & Bear Lake & ID & -111.2792 & 42.5056 & $10 \mathrm{~S}$ & $44 \mathrm{E}$ & 35 & NESESW \\
\hline WPD2030C & C-185795 & Waterloo Mine & waste dump & composite & $\begin{array}{l}\text { dark gray to black } \\
\text { phosphatic shale }\end{array}$ & $09 / 12 / 00$ & Montpelier Canyon & Bear Lake & ID & -111.2400 & 42.3119 & $13 S$ & $45 \mathrm{E}$ & 7 & NENW \\
\hline WPD2031C & C-185796 & Waterloo Mine & waste dump & composite & $\begin{array}{l}\text { beige-tan fissile sandy } \\
\text { shale and limestone } \mathrm{w} / \\
\text { brown-orange iron oxide } \\
\text { stains }\end{array}$ & $09 / 12 / 00$ & Montpelier Canyon & Bear Lake & ID & -111.2397 & 42.3117 & $13 \mathrm{~S}$ & $45 \mathrm{E}$ & 7 & NENW \\
\hline
\end{tabular}


Table A-2. Individual and ICP-10 analyses. (C_Tot, total carbon; C_Crbt, carbonate C; ppm, parts per million; \%, percent; NA = not analyzed; < = less than).

\begin{tabular}{|c|c|c|c|c|c|c|c|c|c|c|c|c|c|c|c|c|c|c|c|c|}
\hline \multirow{2}{*}{$\begin{array}{l}\text { SAMPLE } \\
\text { FIELD } \\
\text { NUMBER }\end{array}$} & \multicolumn{10}{|c|}{ INDIVIDUAL ANALYSES } & \multicolumn{10}{|c|}{ ICP-10 PACKAGE ANALYSES } \\
\hline & $\begin{array}{l}\text { As, } \\
\text { ppm }\end{array}$ & $\begin{array}{l}\mathrm{Hg}, \\
\mathrm{ppm}\end{array}$ & $\begin{array}{l}\text { Se, } \\
\text { ppm }\end{array}$ & $\begin{array}{l}\mathrm{Sb}, \\
\mathrm{ppm}\end{array}$ & Te, ppm & $\mathrm{TI}, \mathrm{ppm}$ & $\underset{\%}{\text { C_Tot, }}$ & $\mathrm{CO} 2, \%$ & C_Crbt, \% & S, \% & $\begin{array}{l}\mathrm{Ag}, \\
\mathrm{ppm}\end{array}$ & $\begin{array}{l}\text { As, } \\
\text { ppm }\end{array}$ & $\begin{array}{l}\text { Au, } \\
\text { ppm }\end{array}$ & $\begin{array}{l}\mathrm{Bi} \text {, } \\
\mathrm{ppm}\end{array}$ & $\begin{array}{l}\text { Cd, } \\
\text { ppm }\end{array}$ & $\begin{array}{l}\mathrm{Cu}, \\
\text { ppm }\end{array}$ & $\begin{array}{l}\text { Mo, } \\
\text { ppm }\end{array}$ & $\begin{array}{l}\mathrm{Pb}, \\
\mathrm{ppm}\end{array}$ & $\begin{array}{l}\mathrm{Sb}, \\
\mathrm{ppm}\end{array}$ & Zn, ppm \\
\hline WPD2001C & 30.4 & 0.49 & 33.1 & 5.1 & $<0.1$ & 1.7 & 4.16 & 3.33 & 0.91 & 0.50 & 4.2 & 20 & 0.2 & 3 & 38.3 & 116.0 & 31.3 & 9 & 5 & 1169.6 \\
\hline WPD2002C & 16.2 & 0.20 & 20.6 & 6.3 & $<0.1$ & 1.0 & 1.77 & 2.14 & 0.58 & 0.17 & 1.7 & 12 & $<0.1$ & 1 & 21.0 & 62.9 & 7.0 & 11 & 7 & 435.0 \\
\hline WPD2003C & 38.1 & 0.68 & 20.5 & 6.3 & 0.1 & 1.7 & 2.08 & 0.43 & 0.12 & 0.31 & 5.7 & 33 & 0.3 & 3 & 15.5 & 117.0 & 42.4 & 11 & 6 & 997.0 \\
\hline WPD2004C & 17.6 & 0.33 & 9.4 & 4.5 & 0.1 & 1.5 & 2.83 & 2.93 & 0.80 & 0.43 & 3.3 & 10 & 0.2 & 3 & 65.7 & 69.0 & 15.2 & 10 & 4 & 683.0 \\
\hline WPD2005C & 33.2 & 0.78 & 33.2 & 9.8 & 0.2 & 1.0 & 4.31 & 5.09 & 1.39 & 0.37 & 9.4 & 27 & 0.2 & 3 & 25.5 & 132.0 & 36.1 & 11 & 8 & 1149.0 \\
\hline WPD2006C & 17.2 & 0.35 & 84.0 & 7.2 & $<0.1$ & 13.7 & 7.81 & 5.73 & 1.56 & 1.70 & 4.3 & 14 & 0.5 & 9 & 231.0 & 85.7 & 108.0 & 14 & 7 & 3418.7 \\
\hline WPD2007C & 18.3 & 0.25 & 35.8 & 4.3 & $<0.1$ & 3.6 & 5.87 & 8.35 & 2.28 & 1.59 & 4.4 & 15 & 0.4 & 6 & 101.0 & 55.0 & 69.5 & 11 & 3 & 1768.0 \\
\hline WPD2008C & 17.2 & 0.25 & 37.5 & 4.6 & $<0.1$ & 4.0 & 5.98 & 7.22 & 1.97 & 1.33 & 4.5 & 14 & 0.4 & 5 & 99.6 & 54.5 & 57.3 & 10 & 4 & 1824.0 \\
\hline WPD2009C & 28.4 & 0.25 & 3.6 & 5.3 & NA & 0.3 & 2.12 & 6.37 & 1.74 & 0.92 & NA & NA & NA & NA & NA & NA & NA & NA & NA & NA \\
\hline WPD2010C & 13.4 & 0.11 & 32.7 & 2.9 & NA & 3.7 & 3.48 & 5.20 & 1.42 & 1.49 & NA & NA & NA & NA & NA & NA & NA & NA & NA & NA \\
\hline WPD2011C & 42.6 & 0.36 & 77.9 & 6.1 & NA & 3.3 & 6.63 & 5.49 & 1.50 & 1.48 & NA & NA & NA & NA & NA & NA & NA & NA & NA & NA \\
\hline WPD2012C & 36.0 & 0.44 & 51.2 & 11.6 & NA & 12.0 & 5.79 & 4.73 & 1.29 & 0.94 & NA & NA & NA & NA & NA & NA & NA & NA & NA & NA \\
\hline WPQ2013C & 38.4 & 0.92 & 71.7 & 11.1 & NA & 2.1 & 6.98 & 5.39 & 1.47 & 0.79 & NA & NA & NA & NA & NA & NA & NA & NA & NA & NA \\
\hline WPD2014C & 92.8 & 0.36 & 66.9 & 10.7 & NA & 3.4 & 8.13 & 7.52 & 2.05 & 1.49 & NA & NA & NA & NA & NA & NA & NA & NA & NA & NA \\
\hline WPD2015C & 45.1 & 0.46 & 285.0 & 24.3 & NA & 13.6 & 9.35 & 2.90 & 0.79 & 2.07 & NA & NA & NA & NA & NA & NA & NA & NA & NA & NA \\
\hline WPD2016C & 40.6 & 0.47 & 16.9 & 8.1 & NA & 4.0 & 4.81 & 6.84 & 1.87 & 0.64 & NA & NA & NA & NA & NA & NA & NA & NA & NA & NA \\
\hline WPD2017C & 32.6 & 0.55 & 147.0 & 8.1 & NA & 1.7 & 10.20 & 1.44 & 0.39 & 1.02 & NA & NA & NA & NA & NA & NA & NA & NA & NA & NA \\
\hline WPD2018C & 23.6 & 0.31 & 23.5 & 3.2 & NA & 1.6 & 2.05 & 0.87 & 0.24 & 0.13 & NA & NA & NA & NA & NA & NA & NA & NA & NA & NA \\
\hline WPD2019C & 26.5 & 0.36 & 23.2 & 3.3 & NA & 1.1 & 3.00 & 4.26 & 1.16 & 0.29 & NA & NA & NA & NA & NA & NA & NA & NA & NA & NA \\
\hline WPD2020C & 22.2 & 0.36 & 20.7 & 3.9 & NA & 1.8 & 2.58 & 1.07 & 0.29 & 0.26 & NA & NA & NA & NA & NA & NA & NA & NA & NA & NA \\
\hline WPD2021C & 9.9 & 0.15 & 14.3 & 1.6 & NA & 1.7 & 9.57 & 30.20 & 8.24 & 0.20 & NA & NA & NA & NA & NA & NA & NA & NA & NA & NA \\
\hline WPD2022C & 24.1 & 0.39 & 19.2 & 4.7 & NA & 4.6 & 3.06 & 2.42 & 0.66 & 0.30 & NA & NA & NA & NA & NA & NA & NA & NA & NA & NA \\
\hline WPD2023C & 26.2 & 0.49 & 16.9 & 4.5 & NA & 1.5 & 3.35 & 0.36 & 0.10 & 0.31 & NA & NA & NA & NA & NA & NA & NA & NA & NA & NA \\
\hline WPD2024C & 34.2 & 0.48 & 80.8 & 5.0 & NA & 1.7 & 8.32 & 2.56 & 0.70 & 2.17 & NA & NA & NA & NA & NA & NA & NA & NA & NA & NA \\
\hline WPD2025C & 10.8 & 0.30 & 8.5 & 2.3 & NA & 0.8 & 5.78 & 14.30 & 3.90 & 0.59 & NA & NA & NA & NA & NA & NA & NA & NA & NA & NA \\
\hline WPQ2026C & 30.0 & 0.75 & 9.0 & 10.3 & NA & 5.5 & 1.55 & 0.84 & 0.23 & 0.29 & NA & NA & NA & NA & NA & NA & NA & NA & NA & NA \\
\hline WPD2027C & 15.8 & 0.13 & 9.1 & 1.8 & NA & 1.2 & 2.28 & 4.78 & 1.30 & 0.10 & NA & NA & NA & NA & NA & NA & NA & NA & NA & NA \\
\hline WPQ2028C & 14.4 & $<0.02$ & 1.3 & 3.5 & NA & $<0.1$ & 0.47 & 0.45 & 0.12 & $<0.05$ & NA & NA & NA & NA & NA & NA & NA & NA & NA & NA \\
\hline WPD2029C & 13.3 & 0.22 & 13.2 & 4.0 & NA & 1.2 & 3.05 & 4.05 & 1.11 & 0.23 & NA & NA & NA & NA & NA & NA & NA & NA & NA & NA \\
\hline WPD2030C & 26.4 & 0.29 & 33.1 & 6.5 & NA & 0.9 & 6.86 & 15.40 & 4.20 & 0.73 & NA & NA & NA & NA & NA & NA & NA & NA & NA & NA \\
\hline WPD2031C & 5.6 & 0.02 & 1.3 & 0.8 & NA & 0.4 & 3.89 & 13.80 & 3.77 & $<0.05$ & NA & NA & NA & NA & NA & NA & NA & NA & NA & NA \\
\hline
\end{tabular}


Table A-3. ICP-16 analyses (ppm, parts per million; \%, percent; $<=$ less than; $>=$ greater than).

\begin{tabular}{|c|c|c|c|c|c|c|c|c|c|c|c|c|c|c|c|c|}
\hline \multirow{2}{*}{$\begin{array}{l}\text { SAMPLE FIELD } \\
\text { NUMBER }\end{array}$} & \multicolumn{16}{|c|}{ ICP-16 PACKAGE ANALYSES } \\
\hline & e & & & & & & $P, \%$ & Si, & $\mathrm{Ti}, \%$ & $\begin{array}{l}\mathrm{Ba}, \\
\mathrm{ppm}\end{array}$ & $\begin{array}{l}\text { Cr, } \\
\text { ppm }\end{array}$ & $\begin{array}{l}\text { Mn, } \\
\text { ppm }\end{array}$ & $\begin{array}{l}\mathrm{Nb}, \\
\mathrm{ppm}\end{array}$ & $\begin{array}{l}\text { Sr, } \\
\text { ppm }\end{array}$ & $\begin{array}{c}\mathrm{Y}, \\
\mathrm{ppm}\end{array}$ & $\begin{array}{l}\mathrm{Zr}, \\
\mathrm{ppm}\end{array}$ \\
\hline WPD2001C & 3.37 & 12.90 & 1.62 & 1.43 & 0.56 & 0.60 & 5.05 & 19.80 & 0.23 & 195 & 1030 & 213 & $<10$ & 537 & 172 & 170 \\
\hline WPD2002C & 4.80 & 5.64 & 2.55 & 1.83 & 1.02 & 0.72 & 2.09 & 26.00 & 0.29 & 319 & 440 & 1280 & $<10$ & 216 & 89 & 195 \\
\hline WPD2003C & 4.51 & 9.09 & 2.30 & 1.88 & 0.18 & 0.92 & 3.76 & 23.00 & 0.33 & 242 & 1630 & 281 & $<10$ & 482 & 193 & 239 \\
\hline WPD2004C & 2.40 & 20.50 & 1.15 & 0.92 & 0.39 & 0.63 & 8.15 & 13.90 & 0.15 & 181 & 666 & 168 & $<10$ & 560 & 126 & 66 \\
\hline WPD2005C & 4.02 & 11.30 & 1.98 & 1.83 & 0.50 & 0.59 & 3.29 & 20.40 & 0.26 & 235 & 1900 & 212 & 14 & 572 & 138 & 159 \\
\hline WPD2006C & 1.10 & 25.80 & 0.60 & 0.55 & 0.95 & 0.77 & 10.50 & 6.26 & 0.08 & 102 & 614 & $<100$ & $<10$ & 843 & 102 & 96 \\
\hline WPD2007C & 2.18 & 22.30 & 0.99 & 0.73 & 0.62 & 0.42 & 7.32 & 11.00 & 0.16 & 151 & 648 & 116 & $<10$ & 682 & 119 & 141 \\
\hline WPD2008C & 1.46 & 26.80 & 0.69 & 0.50 & 0.35 & 0.30 & 9.37 & 7.12 & 0.10 & 93 & 635 & 146 & 14 & 863 & 132 & 89 \\
\hline WPD2009C & \begin{tabular}{|l|l|}
0.41 \\
\end{tabular} & 33.70 & 0.50 & 0.23 & 0.17 & 0.97 & 11.80 & \begin{tabular}{|l|}
4.62 \\
\end{tabular} & 0.03 & 95 & 447 & $<100$ & $<10$ & 1130 & 485 & 72 \\
\hline WPD2010C & 0.98 & 29.90 & 0.55 & 0.48 & 0.58 & 0.82 & 11.10 & 6.82 & 0.08 & 104 & 563 & $<100$ & $<10$ & 963 & 173 & 102 \\
\hline WPD2011C & 1.51 & 25.20 & 0.76 & 0.82 & 0.86 & 0.52 & 9.38 & 7.79 & 0.10 & 96 & 1010 & $<100$ & $<10$ & 884 & 321 & 105 \\
\hline WPD2012C & 4.51 & 7.02 & 1.99 & 1.81 & 1.61 & 0.46 & 1.88 & 23.60 & 0.31 & 339 & 1180 & 119 & $<10$ & 179 & 119 & 266 \\
\hline WPQ2013C & 2.49 & 20.10 & 1.34 & 1.11 & 0.49 & 0.17 & 7.09 & 11.10 & 0.14 & 179 & 2050 & $<100$ & $<10$ & 778 & 278 & 99 \\
\hline WPD2014C & 3.85 & 11.60 & 1.69 & 1.90 & 1.22 & 0.76 & 2.59 & 19.20 & 0.26 & 223 & 833 & 256 & $<10$ & 472 & 117 & 229 \\
\hline WPD2015C & 4.78 & 6.73 & 2.21 & 1.94 & 1.00 & 0.51 & 2.05 & 22.20 & 0.33 & 222 & 1180 & 144 & $<10$ & 197 & 129 & 268 \\
\hline WPD2016C & 1.39 & 27.40 & 0.70 & 0.78 & 1.01 & 0.33 & 9.64 & 7.63 & 0.08 & 129 & 699 & $<100$ & $<10$ & 624 & 146 & 81 \\
\hline WPD2017C & 3.55 & 11.90 & 1.74 & 1.34 & 0.45 & 0.51 & 4.94 & 18.60 & 0.22 & 195 & 1950 & 118 & $<10$ & 646 & 248 & 196 \\
\hline WPD2018C & 5.22 & 4.34 & 2.40 & 1.69 & 0.61 & 0.50 & 1.59 & 29.10 & 0.31 & 280 & 1090 & 311 & 13 & 240 & 117 & 247 \\
\hline WPD2019C & 3.33 & 10.20 & 1.68 & 1.24 & 1.11 & 0.65 & 3.41 & 24.10 & 0.23 & 203 & 798 & 186 & $<10$ & 526 & 143 & 217 \\
\hline WPD2020C & 4.20 & 10.80 & 1.88 & 1.40 & 0.50 & 0.62 & 4.34 & 23.40 & 0.27 & 273 & 986 & 297 & $<10$ & 482 & 173 & 252 \\
\hline WPD2021C & 1.21 & 17.60 & 0.57 & 0.53 & 8.31 & 0.24 & 1.44 & 9.89 & 0.08 & 63 & 405 & 124 & $<10$ & 246 & 56 & 71 \\
\hline WPD2022C & 4.18 & 9.70 & 1.82 & 1.44 & 0.85 & 0.46 & 3.68 & 24.10 & 0.26 & 200 & 1110 & 255 & 10 & 468 & 157 & 221 \\
\hline WPD2023C & 4.41 & 7.78 & 1.83 & 1.55 & 0.24 & 0.70 & 3.85 & 24.90 & 0.30 & 244 & 1370 & $<100$ & $<10$ & 766 & 187 & 301 \\
\hline WPD2024C & 3.57 & 13.40 & 1.93 & 1.66 & 0.73 & 0.45 & 5.22 & 17.50 & 0.22 & 198 & 1270 & $<100$ & 12 & 625 & 176 & 169 \\
\hline WPD2025C & 1.27 & 24.60 & 0.36 & 0.68 & 3.77 & 0.32 & 7.68 & \begin{tabular}{|l|l|} 
& \\
\end{tabular} & 0.08 & 84 & 685 & $<100$ & $<10$ & 779 & 143 & 77 \\
\hline WPQ2026C & 3.15 & 19.00 & 1.45 & 1.29 & 0.28 & 0.24 & 7.90 & 16.80 & 0.19 & 243 & 1620 & $<100$ & 12 & 590 & 298 & 176 \\
\hline WPD2027C & 4.03 & 8.43 & 1.69 & \begin{tabular}{|l|l|}
1.49 \\
\end{tabular} & 1.22 & 0.59 & 2.12 & 26.90 & 0.24 & 380 & 387 & 326 & $<10$ & 281 & 81 & 282 \\
\hline WPQ2028C & 0.50 & 1.36 & $>30$ & 0.20 & 0.14 & 0.07 & 18.00 & 6.08 & 1.50 & 134 & 39630 & 2430 & 138 & 50 & 15 & 431 \\
\hline WPD2029C & 3.03 & 14.80 & 1.54 & 1.24 & 0.95 & 0.38 & 4.66 & 18.40 & 0.19 & 200 & 650 & 569 & 10 & 533 & 118 & 142 \\
\hline WPD2030C & 2.52 & 15.00 & 1.03 & 1.31 & 3.44 & 0.31 & 3.00 & 12.80 & 0.15 & 140 & 573 & 128 & $<10$ & 400 & 126 & 100 \\
\hline WPD2031C & 3.11 & 12.00 & 1.39 & 1.17 & 0.69 & 0.45 & 0.37 & 20.80 & 0.21 & 416 & 65 & 394 & $<10$ & 193 & 21 & 102 \\
\hline
\end{tabular}


Table A-4. ICP-40 analyses (ppm, parts per million; \%, percent; < = less than).

\begin{tabular}{|c|c|c|c|c|c|c|c|c|c|c|c|c|c|c|c|c|c|c|c|c|}
\hline \multirow{2}{*}{$\begin{array}{l}\text { SAMPLE } \\
\text { FIELD } \\
\text { NUMBER }\end{array}$} & \multicolumn{20}{|c|}{ ICP-40 PACKAGE ANALYSES } \\
\hline & Al, \% & $\mathrm{Ca}, \%$ & $\mathrm{Fe}, \%$ & $K, \%$ & Mg, \% & $\mathrm{Na}, \%$ & $\mathbf{P}, \%$ & $\mathrm{Ti}, \%$ & $\begin{array}{c}\mathrm{Ag}, \\
\mathrm{ppm}\end{array}$ & $\begin{array}{l}\text { As, } \\
\text { ppm }\end{array}$ & $\begin{array}{c}\mathrm{Au}, \\
\mathrm{ppm}\end{array}$ & $\begin{array}{l}\mathrm{Ba}, \\
\mathrm{ppm}\end{array}$ & $\begin{array}{c}\mathrm{Be}, \\
\mathrm{ppm}\end{array}$ & $\begin{array}{l}\mathrm{Bi} \text {, } \\
\text { ppm }\end{array}$ & $\begin{array}{l}\text { Cd, } \\
\text { ppm }\end{array}$ & $\begin{array}{l}\text { Ce, } \\
\text { ppm }\end{array}$ & $\begin{array}{l}\text { Co, } \\
\text { ppm }\end{array}$ & $\begin{array}{c}\text { Cr, } \\
\text { ppm }\end{array}$ & $\begin{array}{l}\mathrm{Cu}, \\
\mathrm{ppm}\end{array}$ & $\begin{array}{l}\text { Eu, } \\
\text { ppm }\end{array}$ \\
\hline WPD2001C & 3.558 & 12.000 & 1.60 & 1.48 & 0.513 & 0.420 & 4.895 & 0.127 & 5 & 20 & $<8$ & 207 & $<1$ & $<50$ & 35 & 49 & 5 & 780 & 100 & 3 \\
\hline WPD2002C & 5.067 & 5.834 & 2.60 & 1.91 & 1.002 & 0.575 & 2.195 & 0.222 & $<2$ & 17 & $<8$ & 340 & $<1$ & $<50$ & 19 & 51 & 7 & 290 & 65 & 2 \\
\hline WPD2003C & 4.686 & 9.516 & 2.29 & 1.92 & 0.166 & 0.801 & 4.180 & 0.152 & 8 & 26 & $<8$ & 275 & $<1$ & $<50$ & 15 & 63 & 8 & 1600 & 117 & 4 \\
\hline WPD2004C & 2.519 & 20.200 & 1.13 & 1.06 & 0.385 & 0.438 & 8.945 & 0.114 & 4 & 10 & $<8$ & 208 & $<1$ & $<50$ & 62 & 48 & 5 & 334 & 78 & 2 \\
\hline WPD2005C & 4.239 & 11.300 & 2.01 & 1.89 & 0.499 & 0.447 & 3.700 & 0.152 & 12 & 19 & $<8$ & 235 & $<1$ & $<50$ & 25 & 52 & 5 & 1880 & 130 & 3 \\
\hline WPD2006C & 1.208 & 25.100 & 0.72 & 0.62 & 0.964 & 0.651 & 11.500 & 0.070 & 3 & 13 & $<8$ & 122 & $<1$ & $<50$ & 225 & 24 & 3 & 690 & 102 & $<2$ \\
\hline WPD2007C & 2.298 & 22.200 & 0.97 & 0.83 & 0.618 & 0.310 & 8.310 & 0.102 & 3 & 13 & $<8$ & 178 & $<1$ & $<50$ & 90 & 31 & 4 & 720 & 63 & $<2$ \\
\hline WPD2008C & 1.546 & 25.900 & 0.64 & 0.59 & 0.361 & 0.226 & 10.600 & 0.070 & 3 & 11 & $<8$ & 103 & $<1$ & $<50$ & 97 & 25 & 3 & 738 & 69 & $<2$ \\
\hline WPD2009C & 0.405 & 31.700 & 0.46 & 0.25 & 0.160 & 0.990 & 11.900 & 0.017 & 2 & 11 & $<8$ & 88 & $<1$ & $<50$ & 51 & 65 & $<2$ & 304 & 57 & 8 \\
\hline WPD2010C & 1.080 & 27.200 & 0.57 & 0.53 & 0.585 & 0.860 & 12.000 & 0.050 & $<2$ & 18 & $<8$ & 110 & $<1$ & $<50$ & 77 & 14 & $<2$ & 370 & 38 & 2 \\
\hline WPD2011C & 1.590 & 24.000 & 0.76 & 0.89 & 0.840 & 0.550 & 10.100 & 0.050 & 5 & 39 & $<8$ & 103 & $<1$ & $<50$ & 94 & 51 & $<2$ & 448 & 102 & 4 \\
\hline WPD2012C & 4.635 & 6.625 & 1.98 & 1.97 & 1.540 & 0.490 & 1.915 & 0.209 & 7 & 29 & $<8$ & 334 & $<1$ & $<50$ & 79 & 69 & 2 & 716 & 80 & 2 \\
\hline WPQ2013C & 2.500 & 18.600 & 1.23 & 1.17 & 0.455 & 0.185 & 7.270 & 0.055 & 14 & 26 & $<8$ & 181 & $<1$ & $<50$ & 85 & 43 & $<2$ & 1470 & 221 & 5 \\
\hline WPD2014C & 4.125 & 11.300 & 1.79 & 2.03 & 1.185 & 0.810 & 2.855 & 0.182 & 5 & 85 & $<8$ & 237 & $<1$ & $<50$ & 64 & 51 & 4 & 942 & 71 & 2 \\
\hline WPD2015C & 4.975 & 6.285 & 2.26 & 2.04 & 0.950 & 0.555 & 2.125 & 0.270 & 11 & 39 & $<8$ & 242 & $<1$ & $<50$ & 186 & 61 & 3 & 1340 & 94 & 2 \\
\hline WPD2016C & 1.445 & 24.900 & 0.69 & 0.82 & 1.035 & 0.335 & 10.200 & 0.050 & 5 & 42 & $<8$ & 137 & $<1$ & $<50$ & 65 & 31 & 3 & 340 & 69 & $<2$ \\
\hline WPD2017C & 3.385 & 11.400 & 1.64 & 1.38 & 0.410 & 0.530 & 5.130 & 0.094 & 11 & 25 & $<8$ & 189 & $<1$ & $<50$ & 43 & 61 & 3 & 555 & 230 & 4 \\
\hline WPD2018C & 5.230 & 4.160 & 2.39 & 1.78 & 0.590 & 0.530 & 1.680 & 0.226 & 4 & 25 & $<8$ & 287 & 1 & $<50$ & 13 & 50 & 7 & 690 & 85 & 3 \\
\hline WPD2019C & 3.380 & 9.760 & 1.75 & 1.33 & 1.045 & 0.685 & 3.745 & 0.121 & 5 & 21 & $<8$ & 201 & $<1$ & $<50$ & 23 & 64 & 4 & 536 & 62 & 3 \\
\hline WPD2020C & 4.220 & 10.100 & 1.85 & 1.47 & 0.465 & 0.650 & 4.545 & 0.121 & 7 & 18 & $<8$ & 269 & $<1$ & $<50$ & 36 & 58 & 6 & 510 & 89 & 3 \\
\hline WPD2021C & 1.325 & 16.700 & 0.56 & 0.57 & 8.365 & 0.245 & 1.570 & 0.044 & $<2$ & $<10$ & $<8$ & 64 & $<1$ & $<50$ & 40 & 16 & $<2$ & 180 & 34 & $<2$ \\
\hline WPD2022C & 4.135 & 9.345 & 1.81 & 1.53 & 0.830 & 0.470 & 3.890 & 0.116 & 8 & 23 & $<8$ & 211 & $<1$ & $<50$ & 61 & 54 & 6 & 644 & 104 & 3 \\
\hline WPD2023C & 4.445 & 7.285 & 1.80 & 1.60 & 0.220 & 0.715 & 3.955 & 0.138 & 9 & 18 & $<8$ & 255 & $<1$ & $<50$ & 28 & 70 & $<2$ & 677 & 123 & 3 \\
\hline WPD2024C & 3.715 & 12.800 & 1.83 & 1.82 & 0.695 & 0.485 & 5.435 & 0.116 & 6 & 26 & $<8$ & 208 & $<1$ & $<50$ & 17 & 62 & 4 & 340 & 93 & 3 \\
\hline WPD2025C & 1.290 & 23.300 & 0.36 & 0.72 & 3.740 & 0.345 & 8.165 & 0.044 & 6 & $<10$ & $<8$ & 89 & $<1$ & $<50$ & 71 & 24 & $<2$ & 361 & 72 & $<2$ \\
\hline WPQ2026C & 3.215 & 18.200 & 1.40 & 1.40 & 0.275 & 0.245 & 8.485 & 0.083 & 21 & 23 & $<8$ & 255 & $<1$ & $<50$ & 145 & 58 & $<2$ & 1210 & 183 & 5 \\
\hline WPD2027C & 4.135 & 7.870 & 1.73 & 1.55 & 1.185 & 0.610 & 2.260 & 0.187 & 3 & 18 & $<8$ & 388 & $<1$ & $<50$ & 17 & 61 & 6 & 122 & 40 & $<2$ \\
\hline WPQ2028C & 0.490 & 1.270 & 31.60 & 0.20 & 0.125 & 0.067 & 18.500 & 0.337 & 27 & 20 & $<8$ & 121 & 2 & 52 & $<2$ & 26 & 111 & 30800 & 4330 & 9 \\
\hline WPD2029C & 3.215 & 14.500 & 1.62 & 1.34 & 0.914 & 0.385 & 5.095 & 0.100 & 3 & 11 & $<8$ & 199 & 2 & $<50$ & 26 & 43 & 5 & 330 & 70 & $<2$ \\
\hline WPD2030C & 2.720 & 14.800 & 1.12 & 1.43 & 3.444 & 0.325 & 3.280 & 0.095 & 5 & 29 & $<8$ & 154 & 1 & $<50$ & 26 & 33 & $<2$ & 198 & 49 & 2 \\
\hline WPD2031C & 3.315 & 11.800 & 1.44 & 1.28 & 0.683 & 0.480 & 0.395 & 0.131 & $<2$ & $<10$ & $<8$ & 433 & 1 & $<50$ & 3 & 23 & 5 & 8 & 23 & $<2$ \\
\hline
\end{tabular}


Table A-4. ICP-40 analyses (ppm, parts per million; \%, percent; <= less than). - continued

\begin{tabular}{|c|c|c|c|c|c|c|c|c|c|c|c|c|c|c|c|c|c|c|c|c|}
\hline \multirow{2}{*}{$\begin{array}{l}\text { SAMPLE } \\
\text { FIELD } \\
\text { NUMBER }\end{array}$} & \multicolumn{20}{|c|}{ ICP-40 PACKAGE ANALYSES } \\
\hline & $\begin{array}{c}\text { Ga, } \\
\text { ppm }\end{array}$ & $\begin{array}{l}\text { Ho, } \\
\text { ppm }\end{array}$ & $\begin{array}{l}\text { La, } \\
\text { ppm }\end{array}$ & $\begin{array}{c}\mathrm{Li} \\
\text { ppm }\end{array}$ & $\begin{array}{l}\text { Mn, } \\
\text { ppm }\end{array}$ & $\begin{array}{l}\text { Mo, } \\
\text { ppm }\end{array}$ & $\begin{array}{l}\mathrm{Nb} \text {, } \\
\text { ppm }\end{array}$ & $\begin{array}{l}\text { Nd, } \\
\text { ppm }\end{array}$ & $\begin{array}{c}\mathrm{Ni}, \\
\text { ppm }\end{array}$ & $\begin{array}{l}\mathrm{Pb} \\
\mathrm{ppm}\end{array}$ & $\begin{array}{l}\text { Sc, } \\
\text { ppm }\end{array}$ & $\begin{array}{l}\text { Sn, } \\
\text { ppm }\end{array}$ & $\begin{array}{l}\mathrm{Sr}, \\
\mathrm{ppm}\end{array}$ & $\begin{array}{c}\text { Ta, } \\
\text { ppm }\end{array}$ & $\begin{array}{l}\text { Th, } \\
\text { ppm }\end{array}$ & $\begin{array}{c}\text { U, } \\
\text { ppm }\end{array}$ & $\begin{array}{c}\mathrm{V}, \\
\mathrm{ppm}\end{array}$ & $\begin{array}{c}\mathrm{Y}, \\
\text { ppm }\end{array}$ & $\begin{array}{l}\text { Yb, } \\
\text { ppm }\end{array}$ & $\begin{array}{l}\text { Zn, } \\
\text { ppm }\end{array}$ \\
\hline WPD2001C & 13 & $<4$ & 122 & 21 & 202 & 28 & $<4$ & 77 & 238 & 7 & 9 & $<50$ & 490 & $<40$ & 9 & $<100$ & 406 & 170 & 9 & 1150 \\
\hline WPD2002C & 19 & $<4$ & 77 & 32 & 1240 & 8 & $<4$ & 55 & 88 & 15 & 10 & $<50$ & 211 & $<40$ & 9 & $<100$ & 295 & 97 & 6 & 427 \\
\hline WPD2003C & 18 & $<4$ & 191 & 27 & 304 & 39 & $<4$ & 112 & 297 & 17 & 11 & $<50$ & 488 & $<40$ & 12 & $<100$ & 209 & 218 & 10 & 989 \\
\hline WPD2004C & 10 & $<4$ & 114 & 18 & 164 & 15 & $<4$ & 60 & 118 & 9 & 5 & $<50$ & 558 & $<40$ & 9 & $<100$ & 860 & 145 & 7 & 676 \\
\hline WPD2005C & 17 & $<4$ & 136 & 27 & 240 & 33 & $<4$ & 78 & 334 & 14 & 11 & $<50$ & 565 & $<40$ & 9 & $<100$ & 300 & 158 & 8 & 1210 \\
\hline WPD2006C & 4 & $<4$ & 91 & 11 & 37 & 116 & $<4$ & 45 & 302 & 14 & 3 & $<50$ & 857 & $<40$ & 8 & 154 & 2590 & 120 & 6 & 3570 \\
\hline WPD2007C & 10 & $<4$ & 89 & 13 & 112 & 62 & $<4$ & 45 & 155 & 10 & 4 & $<50$ & 703 & $<40$ & $<6$ & $<100$ & 873 & 143 & 7 & 1540 \\
\hline WPD2008C & 8 & $<4$ & 96 & 11 & 81 & 57 & $<4$ & 49 & 151 & 8 & $<2$ & $<50$ & 841 & $<40$ & 6 & $<100$ & 1070 & 155 & 7 & 1650 \\
\hline WPD2009C & $<4$ & 14 & 420 & 7 & 20 & 7 & $<4$ & 249 & 32 & 16 & $<2$ & $<50$ & 1150 & $<40$ & $<6$ & $<100$ & 96 & 511 & 18 & 404 \\
\hline WPD2010C & 6 & 7 & 105 & 17 & 31 & 17 & $<4$ & 77 & 61 & 16 & 2 & $<50$ & 1020 & $<40$ & $<6$ & $<100$ & 431 & 188 & 7 & 907 \\
\hline WPD2011C & 9 & 4 & 226 & 18 & 57 & 41 & $<4$ & 137 & 185 & 17 & 5 & $<50$ & 966 & $<40$ & $<6$ & $<100$ & 684 & 344 & 13 & 1620 \\
\hline WPD2012C & 45 & 5 & 92 & 29 & 109 & 101 & 9 & 69 & 263 & 21 & 10 & $<50$ & 180 & $<40$ & 9 & $<100$ & 2420 & 127 & 8 & 1330 \\
\hline WPQ2013C & 13 & 6 & 211 & 23 & 51 & 59 & $<4$ & 135 & 289 & 16 & 8 & $<50$ & 829 & $<40$ & $<6$ & $<100$ & 891 & 291 & 13 & 1250 \\
\hline WPD2014C & 25 & $<4$ & 101 & 26 & 242 & 68 & 7 & 77 & 217 & 19 & 8 & $<50$ & 521 & $<40$ & 6 & $<100$ & 891 & 124 & 6 & 1150 \\
\hline WPD2015C & 27 & 5 & 115 & 47 & 139 & 225 & 11 & 78 & 486 & 27 & 10 & $<50$ & 205 & $<40$ & 10 & $<100$ & 3200 & 142 & 9 & 2960 \\
\hline WPD2016C & 9 & 6 & 118 & 13 & 81 & 33 & $<4$ & 81 & 150 & 12 & 3 & $<50$ & 656 & $<40$ & $<6$ & $<100$ & 682 & 156 & 7 & 1110 \\
\hline WPD2017C & 12 & 5 & 184 & 26 & 98 & 47 & 5 & 125 & 243 & 15 & 8 & $<50$ & 652 & $<40$ & 7 & $<100$ & 353 & 261 & 11 & 926 \\
\hline WPD2018C & 16 & 5 & 90 & 34 & 292 & 14 & 14 & 67 & 192 & 14 & 10 & $<50$ & 250 & $<40$ & 8 & $<100$ & 200 & 124 & 7 & 646 \\
\hline WPD2019C & 12 & 5 & 117 & 13 & 175 & 22 & 6 & 83 & 161 & 12 & 7 & $<50$ & 564 & $<40$ & 7 & $<100$ & 198 & 154 & 7 & 771 \\
\hline WPD2020C & 15 & 9 & 114 & 24 & 280 & 21 & 9 & 86 & 187 & 17 & 9 & $<50$ & 509 & $<40$ & 6 & $<100$ & 329 & 181 & 9 & 816 \\
\hline WPD2021C & 20 & $<4$ & 42 & 8 & 121 & 9 & $<4$ & 41 & 117 & 6 & 2 & $<50$ & 258 & $<40$ & $<6$ & $<100$ & 194 & 61 & 3 & 714 \\
\hline WPD2022C & 16 & 6 & 104 & 26 & 266 & 25 & 9 & 75 & 257 & 16 & 9 & $<50$ & 505 & $<40$ & 7 & $<100$ & 633 & 171 & 8 & 1580 \\
\hline WPD2023C & 16 & 5 & 133 & 19 & 28 & 12 & 10 & 82 & 107 & 18 & 10 & $<50$ & 794 & $<40$ & 7 & $<100$ & 282 & 204 & 9 & 440 \\
\hline WPD2024C & 15 & 6 & 146 & 23 & 61 & 41 & 8 & 94 & 214 & 15 & 10 & $<50$ & 667 & $<40$ & $<6$ & $<100$ & 243 & 188 & 9 & 816 \\
\hline WPD2025C & 12 & 5 & 114 & 11 & 79 & 7 & $<4$ & 86 & 97 & 11 & 3 & $<50$ & 815 & $<40$ & $<6$ & $<100$ & 542 & 153 & 7 & 612 \\
\hline WPQ2026C & 16 & 7 & 231 & 26 & 81 & 14 & $<4$ & 148 & 129 & 20 & 7 & $<50$ & 642 & $<40$ & $<6$ & $<100$ & 1620 & 317 & 15 & 986 \\
\hline WPD2027C & 15 & 6 & 77 & 22 & 309 & 6 & 10 & 54 & 66 & 18 & 6 & $<50$ & 300 & $<40$ & 10 & $<100$ & 207 & 86 & 5 & 351 \\
\hline WPQ2028C & 164 & $<4$ & 10 & 3 & 2200 & 1150 & 35 & 88 & 7280 & 10 & $<2$ & $<50$ & 53 & $<40$ & 28 & $<100$ & 35840 & 14 & 39 & 56 \\
\hline WPD2029C & 9 & $<4$ & 90 & 32 & 536 & 15 & $<4$ & 41 & 94 & 35 & 6 & $<50$ & 491 & $<40$ & 9 & $<100$ & 516 & 122 & 7 & 403 \\
\hline WPD2030C & 6 & $<4$ & 101 & 15 & 119 & 28 & $<4$ & 44 & 133 & 7 & 5 & $<50$ & 372 & $<40$ & 11 & $<100$ & 289 & 127 & 7 & 737 \\
\hline WPD2031C & 7 & $<4$ & 21 & 24 & 371 & 3 & 4 & $<9$ & 19 & 13 & 5 & $<50$ & 175 & $<40$ & 8 & $<100$ & 74 & 20 & 2 & 118 \\
\hline
\end{tabular}




\section{APPENDIX B. Metadata}

Identification_Information:

Citation:

Citation_Information:

Originator: Phillip R. Moyle and J. Douglas Causey

Publication_Date: 2001

Title: Chemical Composition of Samples Collected from Waste Rock Dumps and Other Mining-Related Features at Selected Phosphate Mines in Southeastern Idaho, Western Wyoming, and Northern Utah

Edition: 1

Geospatial_Data_Presentation_Form: map

Series_Information:

Series_Name: Open File Report

Issue_Identification: OF 01-411

Publication_Information:

Publication_Place: Menlo Park, CA

Publisher: U. S. Geological Survey

Online_Linkage: http://geopubs.wr.usgs.gov/open-file/of01-411

Description:

Abstract:

This text file contains chemical analyses for 31 samples collected from various phosphate mine

sites in southeastern Idaho (25), northern Utah (2), and western Wyoming (4).

Purpose:

The sampling effort was undertaken as a reconnaissance and does not constitute a characterization of mine

wastes. Twenty-five samples were collected from waste rock dumps, 2 from stockpiles, and 1 each from slag, tailings, mill shale, and an outcrop. All samples were analyzed for a suite of major, minor, and trace elements.

Time_Period_of_Content:

Time_Period_Information:

Single_Date/Time:

Calendar_Date: 2001

Currentness_Reference: publication date

Status:

Progress: Complete

Maintenance_and_Update_Frequency: None planned

Spatial_Domain:

Bounding_Coordinates:

West_Bounding_Coordinate: -112.1294

East_Bounding_Coordinate: -110.5823

North_Bounding_Coordinate: 43.0326

South_Bounding_Coordinate: 40.1008

Keywords: 


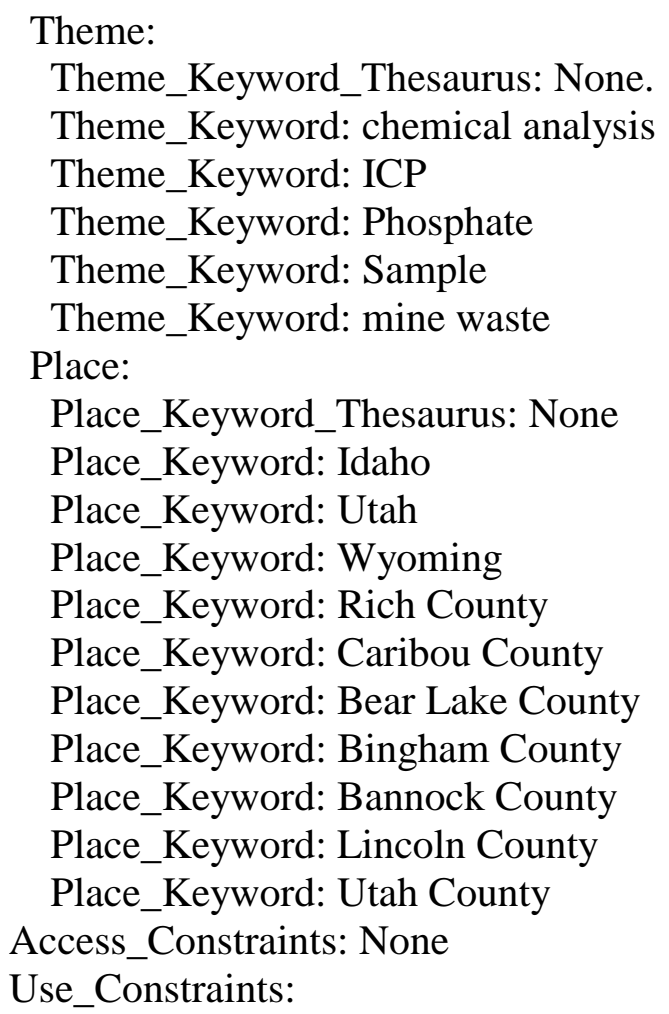

Any hardcopies utilizing these data sets shall clearly indicate their source. If the user has modified the data in any way, they are obligated to describe the types of modifications they have performed. User specifically agrees not to misrepresent these data sets, nor to imply that changes they made were approved by the U.S. Geological Survey.

Point_of_Contact:

Contact_Information:

Contact_Person_Primary:

Contact_Person: Phil Moyle

Contact_Organization: U. S. Geological Survey

Contact_Position: Geologist

Contact_Address:

Address_Type: mailing and physical address

Address: 904 W. Riverside Ave., Rm 202

City: Spokane

State_or_Province: WA

Postal_Code: 99201-1087

Country: USA

Contact_Voice_Telephone: 509.368.3109

Contact_Facsimile_Telephone: 509.368.3199

Contact_Electronic_Mail_Address: pmoyle@usgs.gov

Native_Data_Set_Environment: Microsoft Windows 2000 Version 5.0 (Build 2195) Service Pack 2; ESRI ArcCatalog 8.1.1.649 
Data_Quality_Information:

Attribute_Accuracy:

Attribute_Accuracy_Report:

Attribute accuracy was verified by manual comparison of the

source with topographic maps

Logical_Consistency_Report: Longitude and latitude information is unique location for each point

Completeness_Report: All data created by this project

Positional_Accuracy:

Horizontal_Positional_Accuracy:

Horizontal_Positional_Accuracy_Report: +- 10 meters

Lineage:

Process_Step:

Process_Description: Data reported on spreadsheet was copied and pasted to text file.

Process_Date: 2001

Process_Contact:

Contact_Information:

Contact_Person_Primary:

Contact_Person: J. Douglas Causey

Contact_Organization: U.S. Geological Survey

Contact_Position: Geologist

Contact_Address:

Address_Type: mailing and physical address

Address: 904 W. Riverside Ave., Rm 202

City: Spokane

State_or_Province: WA

Postal_Code: 99201-1087

Country: USA

Contact_Voice_Telephone: 509.368.3116

Contact_Facsimile_Telephone: 509.368.3199

Contact_Electronic_Mail_Address: dcausey@usgs.gov

Hours_of_Service: 8-4 PST

Spatial_Reference_Information:

Horizontal_Coordinate_System_Definition:

Geodetic_Model:

Horizontal_Datum_Name: North American Datum of 1927

Entity_and_Attribute_Information:

Overview_Description:

Entity_and_Attribute_Overview:

The columns and their definitions are listed below. All values that were less than $(<)$ were converted to minus (-).

Samples were processed by several methods. As a result, there was duplication of analyses for some elements.

Rock samples were air dried followed by disaggregation in a mechanical jaw crusher. A split was ground to $<100$ mesh $(0.15 \mathrm{~mm})$ in a ceramic plate grinder. A riffle splitter was used to 
obtain splits to ensure similarity with the whole sample. One set of splits for all samples was archived, and approximately 50-g splits of ground material was shipped to the contract laboratory for analysis.

Forty major, minor, and trace elements were determined for all 31 samples by inductively coupled plasma-atomic emission spectrometry (ICP-AES), also referred to as the ICP-40 package, after low-temperature $(<150 \mathrm{oC})$ digestion using concentrated hydrochloric, hydrofluoric, nitric, and perchloric acids (Crock and others, 1983).

Splits of all samples were also submitted to a contract laboratory for analysis of 16 major, minor, and trace elements (Al, Ba, Ca, Cr, Fe, Mg, Mn, Nb, P, K, Si, Na, Sr, Ti, Y, Zr) by ICPAES

using a lithium metaborate fusion. This technique, also referred to as the ICP-16 package, was used especially to provide analysis of silicon $(\mathrm{Si})$ for these siliceous, phosphatic shale samples. The samples were fused with lithium metaborate in a graphite crucible. In-house standards, and synthetic standards were used to calibrate the instrument. Sample solutions were aspirated into the ICP through a high-solids nebulizer, and metal concentrations were measured simultaneously. Selenium, arsenic, and antimony analyses were accomplished using hydride generation followed by atomic absorption (AA) spectroscopy. Tellurium and thallium were determined using AA graphite furnace spectroscopy. Total sulfur and the various forms of carbon were determined using a LECO furnace followed by gas chromatographic measurement.

Eight samples were also submitted for a 10- element ICP-AES technique, also referred to as ICP10, for determination of $\mathrm{Ag}, \mathrm{As}, \mathrm{Au}, \mathrm{Bi}, \mathrm{Cd}, \mathrm{Cu}, \mathrm{Mo}, \mathrm{Pb}, \mathrm{Sb}$, and $\mathrm{Zn}$. Hydrochloric acidhydrogen peroxide were used to solubilize metals not tightly bound in the silicate lattice of rocks, and metals are extracted as organic halides. Concentrations of the extracted metals were determined simultaneously after aspiration into a multichannel ICP instrument. This procedure is a partial digestion and results may be biased low when compared to procedures involving complete dissolution of the sample.

SEQ_NO -Unique sequence number

LAB_NO -Laboratory number

SAMPLE_NO -Field sample number

DATE_COLL -Date sample collected

SAMP_TYPE -Type of sample taken

FEAT_SAMP -Mine feature sampled

LITHOLOGY -Rock type sampled

SITE_NAME -Name of mine or property where sample collected

QUAD_MAP -U.S. Geological Survey 7.5' Topographic map upon which site is located

COUNTY -County

STATE -State

LONGITUDE -Longitude of sample taken with GPS

LATITUDE $\quad$-Latitude of sample taken with GPS

MERIDIAN -Meridian

TWSP -Township 
RANGE -Range

SECTION -Section

PARCEL -Fractional part of section

As_Hyd_ppm -Arsenic in parts per million analyzed by hydride generation-atomic absorption spectrometry

Hg_CVA_ppm -Mercury in parts per million analyzed by cold vapor atomic absorption

Se_Hyd_ppm -Selenium in parts per million analyzed by hydride generation-atomic absorption spectrometry

Sb_Hyd_ppm -Antimony in parts per million analyzed by hydride generation-atomic absorption spectrometry

Te_Hyd_ppm -Tellurium in parts per million analyzed by hydride generation-atomic absorption spectrometry

Tl_Hyd_ppm -Thallium in parts per million analyzed by hydride generation-atomic absorption spectrometry

C_Tot_pct -Carbon in percent analyzed by combustion in an oxygen atmosphere followed by infrared measurement of evolved $\mathrm{CO} 2$

CO2_Ac_pct -Carbon dioxide in percent evolved after acidification

C_Crbt_pct -Carbonate (inorganic) carbon in percent analyzed by coulometric titration after acidification

S_Tot_pct -Sulfur in percent analyzed by combustion in an oxygen atmosphere followed by infrared measurement of evolved SO2

Ag_10_ppm -Silver in parts per million analyzed by 10 element method

As_10_ppm -Arsenic in parts per million analyzed by 10 element method

Au_10_ppm -Gold in parts per million analyzed by 10 element method

Bi_10_ppm -Bismuth in parts per million analyzed by 10 element method

Cd_10_ppm -Cadmium in parts per million analyzed by 10 element method

$\mathrm{Cu}$ _10_ppm -Copper in parts per million analyzed by 10 element method

Mo_10_ppm -Molybdenum in parts per million analyzed by 10 element method

Pb_10_ppm -Lead in parts per million analyzed by 10 element method

Sb_10_ppm -Antimony in parts per million analyzed by 10 element method

Zn_10_ppm -Zinc in parts per million analyzed by 10 element method

Al_16_pct -Aluminum in percent analyzed by 16 element method

Ca_16_pct-Calcium in percent analyzed by 16 element method

Fe_16_pct -Iron in percent analyzed by 16 element method

K_16_pct -Potassium in percent analyzed by 16 element method

Mg_16_pct -Magnesium in percent analyzed by 16 element method

Na_16_pct-Sodium in percent analyzed by 16 element method

P_16_pct -Phosphorous in percent analyzed by 16 element method

Si_16_pct -Silicon in percent analyzed by 16 element method

Ti_16_pct -Titanium in percent analyzed by 16 element method

Ba_16_ppm -Barium in parts per million analyzed by 16 element method

Cr_16_ppm -Chromium in parts per million analyzed by 16 element method

Mn_16_ppm -Manganese in parts per million analyzed by 16 element method

Nb_16_ppm -Niobium in parts per million analyzed by 16 element method

Sr_16_ppm -Strontium in parts per million analyzed by 16 element method

Y_16_ppm $\quad$-Yittrium in parts per million analyzed by 16 element method 
Zr_16_ppm -Zirconium in parts per million analyzed by 16 element method Al_40_pct -Aluminum in percent analyzed by 40 element method

Ca_40_PCT -Calcium in percent analyzed by 40 element method

Fe_40_pct -Iron in percent analyzed by 40 element method

K_40_pct -Potassium in percent analyzed by 40 element method

Mg_40_pct -Magnesium in percent analyzed by 40 element method

Na_40_pct-Sodium in percent analyzed by 40 element method

P_40_pct -Phosphorous in percent analyzed by 40 element method

Ti_40_pct - Titanium in percent analyzed by 40 element method

Ag_40_ppm -Silver in parts per million analyzed by 40 element method

As_40_ppm -Arsenic in parts per million analyzed by 40 element method

Au_40_ppm -Gold in parts per million analyzed by 40 element method

Ba_40_ppm -Barium in parts per million analyzed by 40 element method

Be_40_ppm -Beryllium in parts per million analyzed by 40 element method

Bi_40_ppm -Bismuth in parts per million analyzed by 40 element method

Cd_40_ppm -Cadmium in parts per million analyzed by 40 element method

Ce_40_ppm -Cerium in parts per million analyzed by 40 element method

Co_40_ppm -Cobalt in parts per million analyzed by 40 element method

Cr_40_ppm -Chromium in parts per million analyzed by 40 element method

$\mathrm{Cu} \_40 \_$ppm $\quad$-Copper in parts per million analyzed by 40 element method

Eu_40_ppm -Europium in parts per million analyzed by 40 element method

Ga_40_ppm -Gallium in parts per million analyzed by 40 element method

Ho_40_ppm -Holmium in parts per million analyzed by 40 element method

La_40_ppm -Lanthanium in parts per million analyzed by 40 element method

Li_40_ppm -Lithium in parts per million analyzed by 40 element method

Mn_40_ppm -Manganese in parts per million analyzed by 40 element method

Mo_40_ppm -Molybdenum in parts per million analyzed by 40 element method

Nb_40_ppm -Niobium in parts per million analyzed by 40 element method

Nd_40_ppm -Neodymium in parts per million analyzed by 40 element method

Ni_40_ppm -Nickel in parts per million analyzed by 40 element method

$\mathrm{Pb} \_40 \_p p m \quad-$ Lead in parts per million analyzed by 40 element method

Sc_40_ppm -Scandium in parts per million analyzed by 40 element method

Sn_40_ppm -Tin in parts per million analyzed by 40 element method

Sr_40_ppm -Strontium in parts per million analyzed by 40 element method

Ta_40_ppm -Tantalum in parts per million analyzed by 40 element method

Th_40_ppm -Thorium in parts per million analyzed by 40 element method

U_40_ppm -Uranium in parts per million analyzed by 40 element method

V_40_ppm -Vanadium in parts per million analyzed by 40 element method

Y_40_ppm -Yittrium in parts per million analyzed by 40 element method

Yb_40_ppm -Ytterbium in parts per million analyzed by 40 element method

Zn_40_ppm -Zirconium in parts per million analyzed by 40 element method

Distribution_Information:

Distributor:

Contact_Information:

Contact_Organization_Primary:

Contact_Organization: U.S. Geological Survey 
Hours_of_Service: 24 hours

Contact_Instructions:

This report is only available in electronic format at

URL = http://geopubs.wr.usgs.gov /open-file/of01-411/ or

via anonymous FTP from geopubs.wr.usgs.gov, in the directory pub/open-file/of01-411.

Distribution_Liability:

The U.S. Geological Survey (USGS) provides these geographic data "as is". The USGS makes no guarantee or warranty concerning the accuracy of information contained in the geographic data. The USGS further make no warranties, either expressed or implied as to any other matter whatsoever, including, without limitation, the condition of the product, or its fitness for any particular purpose. The burden for determined fitness for use lies lies entirely with the user. Although these data have been processed successfully on computers at the USGS, no warranty, expressed or implied, is made by the USGS regarding the use of these data on any other system, nor does the fact of distribution constite or imply any such warranty.

In no event shall the USGS have any liability whatsoever for payment of any consequential, incidental, indirect, special, or tort damages of any kind, including, but not limited to, any loss of profits arising out of the delivery, installation, operation, or support by the USGS.

Standard_Order_Process:

Digital_Form:

Digital_Transfer_Information:

Format_Name: ASCII

Format_Version_Number: 1

File_Decompression_Technique: no compression applied

Digital_Transfer_Option:

Online_Option:

Computer_Contact_Information:

Network_Address:

Network_Resource_Name: http://geopubs.wr.usgs.gov/open-file/of01-411

Fees: None

Ordering_Instructions: Web only publication

Metadata_Reference_Information:

Metadata_Date: 20020103

Metadata_Future_Review_Date: None

Metadata_Contact:

Contact_Information:

Contact_Organization_Primary:

Contact_Organization: U.S. Geological Survey 
Contact_Person: J. Douglas Causey

Contact_Position: Geologist

Contact_Address:

Address_Type: mailing and physical address

Address: 904 W. Riverside Ave., Rm 202

City: Spokane

State_or_Province: WA

Postal_Code: 99208-1087

Country: USA

Contact_Voice_Telephone: 509.368.3116

Contact_Facsimile_Telephone: 509.368.3199

Contact_Electronic_Mail_Address: dcausey@usgs.gov

Hours_of_Service: 8-4 PST

Metadata_Standard_Name: FGDC Content Standards for Digital Geospatial Metadata

Metadata_Standard_Version: FGDC-STD-001-1998

Metadata_Time_Convention: local time

Metadata_Access_Constraints: None

Metadata_Use_Constraints: None 